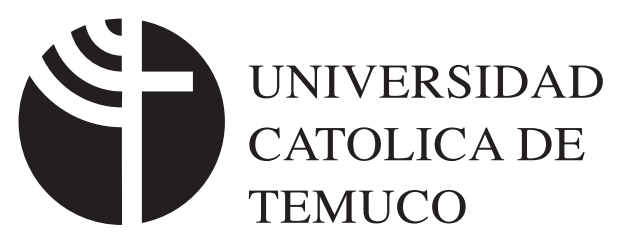

\title{
Revista Chilena de Derecho y Ciencia Política
}

Universidad Católica de Temuco

Escuela de Derecho

Diciembre 2010

Temuco, Chile 
La Revista Chilena de Derecho y Ciencia Política cuenta con la asesoría y financiamiento de la Dirección General de Investigación y Postgrado en el marco de la estrategia de apoyo institucional a las publicaciones científicas UC Temuco.

Volumen 2, Año 1, № 1, ISSN 0718-9389

\title{
Representante legal
}

Temuco - Chile, Diciembre de 2010

\author{
Alberto Vásquez Tapia \\ Director \\ Dr. Jordi Delgado Castro
}

Abogado del Ilustre Colegio de Abogados de Barcelona, Dr. en Derecho, Universidad de Barcelona

\section{Comité Editorial}

Dr. Jordi Delgado (U. Católica de Temuco)

Dr. Iván Díaz (U. Católica de Temuco)

Dr. Rodrigo Coloma (U. Alberto Hurtado)

Dr. Héctor Hernández (U. Diego Portales)

Dr. Jaime Baeza (U. de Chile)

Mg. Judith Schönsteiner (U. Diego Portales)

\section{Comité Científico Internacional}

Dr. Rafael de Asís Roig (U. Carlos III de Madrid)

Dr. Paolo Comanducci (U. de Génova)

Dr. Enrique Rajevic (U. Alberto Hurtado)

Dr. Sabine Michalowsky (University of Essex)

Dra. Clara Sandoval (Pontificia U. Javeriana, Bogotá)

Dr. Jorge D’Agostino (U. Católica, Argentina)

Dr. Miguel Ángel López (U. de Chile)

Dra. Leslie Wehner (GIGA)

Dr. José Luis Vázquez Sotelo (U. de Barcelona)

Dr. David Vallespín (U. de Barcelona)

Dra. Calvo Sánchez (U. de Salamanca)

Mg. Ricardo Reveco (Duke University, Estados Unidos)

Mg. José Ángel Rodríguez (U. Autónoma de Coahuila)

Dr. Robalino Orellana (U. Andina Simón Bolívar, Ecuador)

Dr. Patricio Carvajal (Pontificia Universidad Católica de México)

Sr. David Cienfuegos (U. Nacional Autónoma de México)

Dr. Lorenzo Bujosa (U. de Salamanca)

Dra. Florabel Quispe (U. Carlos III de Madrid)

Ediciones Universidad Católica de Temuco

Manuel Montt 056, Temuco

editorial@uctemuco.cl

Coordinadora

Gabriela Obregón Siegmund

Dirección Revista

Manuel Montt 056, Campus San Francisco, edificio E, tercer piso Teléfono: (56-45) 205 317/ Fax: (56-45) 205497

Correo electrónico: revidere@uctemuco.cl

Diseño Portada

Daniel Ferrera Leiva

Diagramación e impresión:

Alfabeta Artes Gráficas: Carmen 1985, Fono: 3649242

\section{cc) (†) 80}

Esta obra está bajo Licencia Atribución-No Comercial-Licenciar Igual 2.0 Chile de Creative Commons. Quedan los derechos liberados para copiar, distribuir, mostrar y realizar su trabajo y trabajos derivados basados en ella, pero solo para propósitos no comerciales. Nada en esta licencia menoscaba o restringe los derechos morales de los autores. 


\section{ÍNDICE}

SALUDOS PRELIMINARES

PRESENTACIÓN

ARTÍCULOS CIENTÍFICOS

- DERECHO

EL RESARCIMIENTO EN CASO DE DESISTIMIENTO DEL CONTRATO DE OBRA, ¿ES REALMENTE DISTINTO DEL QUE DERIVARÍA DEL RÉGIMEN GENERAL?

Pablo Rodríguez - Palmero Seuma

LAS VIRTUDES JUDICIALES Y LA NOVELA UN JUEZ RURAL DE PEDRO PRADO: APUNTES PARA UN PROBLEMA IDEOLÓGICO

Claudio Agüero San Juan

VERDAD Y JUSTICIA EN AMÉRICA LATINA EN CASOS DE VIOLACIONES A LOS DD.HH.

Héctor Salazar Ardiles

APUNTES SOBRE LAS DIFICULTADES EN LA DETERMINACIÓN DEL ESTATUS CIENTÍFICO DE LA CRIMINOLOGÍA

Sebastián Alonso Agüero San Juan

- CIENCIA POLÍtica

EL ROL DE LA COMISIÓN DE DEFENSA DE LA CÁMARA DE DIPUTADOS EN LA FORMULACIÓN DE LA POLÍTICA DE DEFENSA

JAIME BAEZA ET AL.

- CREA

ALUMNOS MEDIADORES. CONSTRUYENDO LA PAZ

Rosaura Paulero 


\section{- RECENSIÓN}

NEGOCIACIÓN, MEDIACIÓN Y CONCILIACIÓN, COMO MÉTODOS ALTERNATIVOS DE RESOLUCIÓN DE CONTROVERSIAS

Adriana PaLAVECINO

SOBRE NOSOTROS

113 NORMAS DE REDACCIÓN 


\section{SALUDOS PRELIMINARES}

La Facultad de Ciencias Jurídicas de la Universidad Católica de Temuco tiene como gran cometido, entre otros, la formación de profesionales y buenas personas. Para tal efecto, hemos reforzado nuestro proyecto educativo en términos tales que estamos imprimiendo un apoyo más cualitativo a nuestros estudiantes, tanto en lo que guarda relación con la formación teórica del Derecho como con el aprendizaje a través de las Clínicas Jurídicas. Al final del día trabajamos para formar abogados con una sólida formación teórica y práctica, con identidad cristiana y sentido ético.

Uno de los núcleos centrales de nuestra actuación es la promoción del conocimiento. En este contexto, es una misión ineludible de la Universidad contribuir al desarrollo del saber y, por lo tanto, debemos arrogarnos un papel protagónico para la creación de conocimiento científico como bien público útil para nuestra región y para una mejor construcción del país.

La Revista Chilena de Derecho y Ciencia Política es una de nuestras prioridades. Queremos seguir trabajando para convertirla en una publicación que cumpla con los estándares de los índices internacionales que aseguran una calidad acorde a nuestras aspiraciones.

Para el Decano es especialmente satisfactorio poder presentar esta publicación y esta Facultad que nace desde la comprensión e integración de otras disciplinas como un proyecto integral. Por este motivo, en este proyecto se logra una asociación interdisciplinaria entre el derecho y las ciencias políticas.

Les invito, desde estas breves líneas, a disfrutar del esfuerzo de los autores colaboradores con este número y espero que las próximas entregas del año 2011 sean evocadoras de reflexiones que nos motiven como comunidad a ser más críticos, creativos y productivos generadores de conocimiento. 



\section{PRESENTACIÓN}

Cumpliendo con nuestro compromiso semestral, tengo el agrado de poder presentar el segundo número de nuestra publicación. Resulta especialmente gratificante observar cómo el esfuerzo y el trabajo se ven recompensados al poder ofrecer a la comunidad un nuevo ejemplar.

En la misma línea en la que nació este proyecto seguimos ofreciendo tres secciones: la de Derecho, la de Ciencia Política y la de Resolución Alternativa de Conflictos. Además, contamos con una recensión. Como decíamos en el primer número, iremos incorporando en futuras ocasiones comentarios, análisis jurisprudenciales e incluso barajamos la posibilidad de incorporar en una sección especial tesis de posgrado que hayan resultado particularmente interesantes, con el objetivo de ayudar a investigadores noveles a comenzar sus carreras. Como podrá el lector intuir, estamos llenos de proyectos e ilusiones con el norte de contribuir con la ciencia del país.

Este segundo número es misceláneo, por lo tanto distintas temáticas podrán satisfacer a varios lectores. De este modo, sin excluir la posibilidad de publicar números monográficos, la Revista Chilena de Derecho y Ciencia Política tiene una tendencia generalista que aspira a concentrar los esfuerzos de autores de distintos campos y de lectores de diferentes sectores.

Como publicación naciente, pero continuadora de una tradición consolidada, seguimos instando a la comunidad científica a elegir este medio para hacer públicos los resultados de sus investigaciones. Cumpliendo con los criterios de las mejores publicaciones (Scielo), la Revista Chilena de Derecho y Ciencia Política cuenta con normas editoriales, Comité Editorial y un Comité Científico de primer orden internacional que asegura la calidad de nuestros contenidos.

Finalmente, quisiéramos agradecer por sus aportes originales a los autores y por su abnegado trabajo a todos quienes han colaborado en la creación de este ejemplar.

Dr. Jordi Delgado Castro Director de la Revista 



\section{ARTÍCULOS CIENTÍFICOS}





\title{
EL RESARCIMIENTO EN CASO DE DESISTIMIENTO DEL CONTRATO DE OBRA, ¿ES REALMENTE DISTINTO DEL QUE DERIVARÍA DEL RÉGIMEN GENERAL?
}

\author{
IS THE COMPENSATION IN CASE OF WITHDRAWAL OF THE CONSTRUCTION \\ CONTRACT REALLY DIFFERENT FROM THE COMPENSATION UNDER THE \\ GENERAL SYSTEM?
}

Pablo Rodríguez-Palmero Seuma*

Fecha de recepción: 8 abril 2010.

Fecha de aprobación: 11 de mayo 2010.

\begin{abstract}
Resumen:
Generalmente se ha considerado que la facultad de desistir del contrato de obra contemplada en el artículo 1594 del Código Civil español es singular: no solo porque permite al promotor extinguir, por su sola voluntad, el contrato, sino también porque contempla una indemnización especial.

En este trabajo se pone en duda, principalmente, la segunda consideración: teniendo en cuenta que los tres conceptos contemplados en ese artículo normalmente coincidirán con la indemnización derivada de las reglas generales, la posible diferencia entre uno y otro régimen solo puede hallarse en el elemento subjetivo, esto es, en si el promotor ha actuado conscientemente de los daños que causa o no ha tenido otra alternativa que desistir. No obstante, tampoco esta diferencia con el régimen general es tan clara como pudiera pensarse.
\end{abstract}

Palabras clave: contrato de obra, desistimiento, indemnización.

\begin{abstract}
:
It has been generally considered that the power to withdraw from the construction contract referred to in Article 1594 of the Spanish Civil Code is unique, not only because it enables the developer to terminate, voluntarily, the contract but also because it provides a special compensation.

This article mainly questions the second point: given that the three concepts mentioned in this article usually coincide with the compensation arising from the general rules, the possible difference between both systems can only be found in the subjective element, that is, if the developer has acted deliberately, being aware of the damages caused, or if he had no alternative but to withdraw. However, this difference to the general system is not as clear as one might think.
\end{abstract}

Key words: construction contract, withdrawal, compensation.

Responsable de Derecho Procesal,Manubens \& Asociados Abogados (Barcelona - España). prpalmero@ manubens.com 


\section{Características generales del artículo 1594 del Código Civil español}

El artículo 1594 del Código Civil español (en adelante "CC"), casi literal trasunto del 1794 del Código Civil francés ("Le maître peut résilier, par sa simple volonté, le marché a forfait, quoique l'ouvrage soit dejà comencé, en dédommageant l'entrepeneur de toutes ses déspenses, et tous ses travaux, et de tout ce qu'il aurait pu gagner dans cette entreprise") contempla la posibilidad del comitente, dueño o promotor de una obra de desistir unilateralmente de su ejecución, abonando al contratista determinada indemnización, que será posteriormente analizada. Dice el artículo: "El dueño puede desistir, por su sola voluntad, de la construcción de la obra aunque haya empezado, indemnizando al contratista de todos sus gastos, trabajo y utilidad que pudiera obtener de ella". En muy similares términos se pronuncia el artículo 1999 del Código Civil chileno: "Habrá lugar a reclamación de perjuicios, según las reglas generales de los contratos, siempre que por una o por otra parte no se haya ejecutado lo convenido, o se haya retardado su ejecución. Por consiguiente, el que encargó la obra, aun en el caso de haberse estipulado un precio único y total por ella, podrá hacerla cesar, reembolsando al artífice todos los costos, y dándole lo que valga el trabajo hecho y lo que hubiere podido ganar en la obra".

Generalmente, se ha afirmado que nos hallamos ante una singular manifestación de la denuncia o desistimiento unilateral del contrato, no contemplado como modo de extinción de las obligaciones en el artículo 1156 CC pero con otras singulares manifestaciones, concretamente en los contratos que presentan como factor común la confianza: sin carácter exhaustivo, los artículos 1583 CC (respecto del arrendamiento de servicios), $1700.4^{\circ} \mathrm{CC}$ (posibilidad de extinguir el contrato de sociedad por cualquier socio, siempre que lo inste de buena fe y en tiempo pertinente), 1733 CC (facultad del mandante de revocar el encargo), 1750 CC (posibilidad del comodante de pedir la restitución de la cosa, cuando no se haya pactado la duración del contrato), o 1775 CC (extinción del depósito a petición del depositante, aunque se haya pactado un plazo determinado).

Dejando constancia de la duda sobre si todos esos contratos se ven impregnados de tal dosis de confianza que justifique esa extinción unilateral. A continuación nos centramos en el transcrito artículo 1594 CC, comenzando por su fundamento, ejercicio y ámbito:

1. Respecto del fundamento, la mayoría de los autores españoles, pareciendo acudir a motivos de equidad -artículo 3.2 CC- y con base en la antigua doctrina francesa, considera que está constituido por la voluntad de evitar que el comitente pueda arruinarse durante la ejecución de la obra.

En esta línea, analizando el artículo 1535 del Proyecto del CC, ya expresaba GARCÍA GOYENA que el desistimiento "evita que el propietario cuya fortuna se halle comprometida repentinamente por sucesos imprevistos, se arruine comple- 
tamente con gastos en extremo dispendiosos. Puede también ocurrir que la obra no le sea ya útil ni necesaria" (1).

En la actualidad, la misma postura es seguida por autores como DE LA CÁMARA MINGO O RODRÍGUEZ MARÍN (2).

A mi juicio, tal posibilidad de ruina bien podría activar mecanismos menos traumáticos que el desistimiento: por ejemplo, un "ius variandi" similar al previsto, para las servidumbres, en el artículo 545 CC, o, caso de sucesos imprevisibles y de máxima gravedad, la cláusula "rebus sic stantibus". Sea como fuere, se hace necesario advertir que, al aplicar la facultad de denuncia, los Tribunales españoles prescinden por completo del fundamento descrito, pues le otorgan eficacia sin necesidad de que el dueño alegue (mucho menos, acredite) hallarse en una situación patrimonial comprometida.

Por otro lado, el fundamento consistente en que la obra haya devenido inútil o innecesaria para el promotor resulta, sencillamente, inaceptable: se trata de circunstancias cuyas repercusiones en modo alguno pueden lícitamente repercutirse al contratista.

Otros autores han manifestado que el desistimiento es una facultad inherente a la estructura del arrendamiento de obra: por ejemplo, en la doctrina italiana, ABELLO (3). Se trata de un aserto que desconozco si tiene algún contenido adicional a la simple constatación de que, en efecto, esa posibilidad se recoge en el articulado de aquel contrato.

De modo similar, se ha dicho que la denuncia es un privilegio concedido por la Ley al comitente: también en Italia, muy particularmente, MANGINI (4). Así esbozada, esta explicación ni siquiera merece el calificativo de fundamento: limitarse a afirmar que se trata de un privilegio, dado que nos hallamos ante una posibilidad solo excepcionalmente concedida, implica una mera constatación de Derecho positivo, en absoluto una exposición de la razón por la que tal facultad aparece recogida.

El último fundamento conocido del artículo 1594 CC es el ofrecido por SIRVENT GARCÍA, que afirma que, dado que el contrato de obra está principalmente previsto en interés del comitente, no tendría sentido que aquel se mantuviera cuando ese interés se ha desvanecido. Dice este autor: "La razón de ser de la norma contenida en este artículo pensamos que hay que ubicarla en la idea de que el contrato de obra es un instrumento que principalmente está al servicio de los intereses del comitente. Esto supone la necesidad de que el contrato exista sólo mientras el comitente siga teniendo interés en él. No tiene sentido que si el dueño, por la razón que sea, deja de tener interés en la obra se acabe de ejecutar ésta contra su voluntad" (5). 
Semejante concepción del contrato de obra, predicada además con carácter general, se halla perfectamente alejada de la realidad, que demuestra que, en la mayoría de las ocasiones, el contratista tiene en la obra (de cuya ejecución espera obtener importantes y legítimos beneficios) un interés incompatible con la libre posibilidad de que se vea súbitamente privado de ella.

No parece, pues, tarea fácil detectar el fundamento de la norma que estudiamos. Por mi parte, me permito avanzar que tal cúmulo de fracasos en ese bosquejo es síntoma de algo luego desarrollado: no nos hallamos ante una norma tan excepcional como a menudo se considera.

2. En relación con la declaración de voluntad mediante la que se ejercita el desistimiento, es pacíficamente considerada "ad nutum", unilateral -el constructor puede manifestar su rotunda oposición, sin que ello evite la extinción del contrato-, recepticia, irrevocable y no sometida a formalidad alguna.

Por todas, citamos como expresiva de tales caracteres la sentencia del Tribunal Supremo de 17 de junio de 2008 (RJ 2008/4700), que, con cita de otras, manifiesta: "(...) es una declaración de voluntad unilateral, recepticia e irrevocable que no está sometida a forma alguna, si bien conviene que sea notificada al contratista de forma fehaciente, pues ello facilitará la prueba del tiempo en que se produjo el desistimiento, y evitará discusiones sobre reembolsos de obras ejecutadas con posterioridad (aparte de otras, SSTS de 28 de julio de 2000, 31 de mayo de 2001 y 25 de noviembre de 2002)".

No obstante, esta sentencia acaba añadiendo algo que va más allá de lo declarado por otras resoluciones: "(...) la facultad de desistimiento no es ejercitada con corrección si simultáneamente no se ofrece indemnizar al contratista de la obra de todos los gastos, trabajo y utilidad que pudiera obtener de ella".

Al margen de la duda que introduce este pasaje en cuanto a los efectos de un desistimiento sin el contenido mencionado (¿qué significa que aquel no goza de "corrección"?), no parece que ese ofrecimiento pueda considerarse requisito de la denuncia. Obviamente, la liquidación de esas cantidades deberá tener lugar, pero exigir el ofrecimiento de su resarcimiento parece un formalismo excesivo. La mejor prueba de ello es que, como veremos, está admitido el desistimiento tácito.

3. Por lo que respecta al ámbito de aplicación del artículo 1594 CC, dos han sido las cuestiones habitualmente planteadas:

(i) En primer lugar, si únicamente opera en los contratos de obra concertados a precio cerrado (artículo 1593 CC) o tienen aplicación cualquiera que 
haya sido el sistema de fijación del precio. Si bien se trata de una cuestión expresamente resuelta, en el Derecho chileno, por el transcrito artículo 1999 de su Código Civil, en España ha dado lugar a ciertas dudas.

En un primer momento, quizá por influencia del Código Civil francés, cuyo artículo 1794 limita esta facultad a los arrendamientos con precio cerrado, la sentencia del Tribunal Supremo de 22 de junio 1911 (analizando un contrato para el arranque y calcinación de minerales) consideró que el desistimiento solo tenía cabida si el precio era alzado, basándose en el carácter restrictivo de la norma.

En el mismo sentido pareció posicionarse, si bien en un mero "obiter dictum", la sentencia del Alto Tribunal de 23 de noviembre de 1964 (RJ 1964/5453), al analizar un contrato para la impermeabilización de cubiertas.

Sin embargo, en la actualidad es pacífico que, al igual que se reconoce en el Derecho alemán (parágrafo 649 del BGB), el desistimiento puede jugar cualquiera que sea el sistema de fijación del precio y el objeto del contrato, pues el precepto no contiene discriminación sobre el tipo de contrato en los que debe encontrar aplicación ("ubi lex non distinguit, nec nos distinguere debemus"). Por todas, la sentencia del Tribunal Supremo de 25 de octubre de 1984 (RJ 1984/4976): "(...) es ya doctrina reiterada de esta Sala que el artículo 1594 es aplicable a toda clase de contratos de obra, no sólo a los realizados con ajuste a precio alzado-sentencias de 24 de enero y 19 de febrero de 1970 y 19 de noviembre de 1971-, puesto que el texto de esta norma no distingue según las clases de contratos a que haya de aplicarse".

En el mismo sentido, la doctrina: por ejemplo, DE LA CÁMARA MINGO o PUIG BRUTAU (6).

(ii) En segundo lugar, también se ha discutido si el artículo 1594 CC debe aplicarse con indiferencia de quién -comitente o contratista- suministre los materiales (1588 CC: "Puede contratarse la ejecución de una obra, conviniendo en que el que la ejecute ponga solamente su trabajo o su industria, o que también suministre el material").

Con alguna excepción -particularmente, TROPLONG (7)-, la doctrina considera también indiferente esta circunstancia: así se pronuncia, en la doctrina española y por todos, MANRESA (8).

4. Anticipando el tema principal de este artículo, deben dejarse consignadas las diferencias habitualmente predicadas (y más adelante puestas en entredicho) entre el precepto analizado y el general 1124 CC.

Los Tribunales españoles han reiterado hasta la saciedad que ambas normas son nítidamente diferentes, tanto en relación con el supuesto de hecho en ellas contemplados, como -lo que más interesa- respecto de los resarcimientos que otor- 
gan. Tal distinción, ya consagrada por las sentencias del Tribunal Supremo de 24 de enero de 1970 (RJ 1970/254) y 19 de noviembre de 1971 (RJ 1971/4906), ha sido especialmente destacada por sentencias como las de 4 de febrero de 1997 (RJ 1997/675) y 9 de marzo de 1999 (RJ 1999/1408): "El precepto citado [artículo 1594 CC] (...) responde a una situación distinta a la de la resolución del contrato conforme a lo pactado por aplicación del artículo 1124, de manera que no es posible asimilar ni confundir ambos artículos ni sus consecuencias jurídicas (...)".

En términos prácticamente idénticos, la sentencia del mismo Tribunal de 28 de julio de 2000 (RJ 2000/6202): "Decidido por el comitente de la obra el desistimiento de su realización en uso de la facultad que le confiere el art. 1594 del Código Civil (...) no cabe identificar con las consecuencias que, desde lo pactado y por resolución en caso de incumplimiento, establece el art. 1124, del propio Código (...) uno y otro precepto «responden a heterogéneos presupuestos, como también son disímiles sus consecuencias en orden a las respectivas indemnizaciones", reiterando lo que ya habían decidido las que la misma recoge y a las que cabe añadir las de 5 de mayo de 1983, 19 de noviembre de 1984, 7 de octubre de 1986 y, culminando sobre la autonomía entre los dos preceptos, la de 20 de febrero de 1993".

Insiste la sentencia del Tribunal Supremo de 26 de abril de 2005 (RJ 2005/3933): "Se trata de situación jurídica distinta a la de la resolución del contrato que autoriza el artículo 1124, carente de relación con el 1594, y no procede asimilar ni confundir el artículo 1124 con el 1594, como tampoco, lógicamente, sus consecuencias jurídicas".

Llevando al extremo esta doctrina, la sentencia del Alto Tribunal de 25 de noviembre de 2002 (RJ 2002/10275) Ilega a hablar de "incompatibilidad" entre las causas de extinción contractual previstas en los artículos 1594 y 1124 CC.

Actualmente, nuestro Tribunal Supremo sigue manteniendo la misma tesis, como refleja la sentencia de 19 de febrero de 2010: "(...) responden [los artículos 1594 y 1124 CC] a heterogéneos presupuestos, como también son disímiles sus consecuencias en orden a las respectivas indemnizaciones".

Dentro del estudio de la (anunciada) diferencia entre los artículos 1594 y 1124 CC, debemos citar algunas sentencias que, reiterando lo antes transcrito, añaden una expresión cuya posible relevancia será analizada al final de este artículo: me refiero a la manifestación de que el desistimiento puede lícitamente ejercitarse con independencia de los móviles o razones que el propietario pueda albergar.

Afirma, por ejemplo, la sentencia del Tribunal Supremo de 4 de febrero de 2002 (RJ 2002/1595): "(...) el derecho del contratista a percibir la indemnización a que 
se refiere el art. 1594 del Código Civil, no depende en absoluto de los móviles o razones que hayan inducido al propietario del terreno a desistir unilateralmente del contrato de obra concertado (...), libre arbitrio de su titular, sin necesidad de justificación de ninguna clase y depender la eficacia de la acción conferida por el segundo de la conducta observada por cada uno de los contratantes".

Casi literalmente, la sentencia del mismo Tribunal de 25 de noviembre de 2002 (RJ 2002/10275): "(...) el derecho del contratista a percibir la indemnización prevista en el art. 1594 del Código Civil no depende en absoluto de los móviles que hayan inducido al propietario a desistir unilateralmente del contrato de obra".

Por último, citamos la sentencia de 29 de septiembre de 2005 (RJ 2005/8892) "(...) el derecho del contratista a percibir la indemnización a que se refiere el art.1594 del Código Civil, no depende en absoluto de los móviles o razones que hayan inducido al propietario del terreno a desistir del contrato de obra concertado (...), al libre arbitrio de su titular, sin necesidad de justificación de ninguna clase y depender la eficacia de la acción conferida por el segundo de la conducta observada por ninguno de los contratantes".

En concordancia con ello, los Tribunales tienen sentado que el ejercicio de la facultad otorgada por el artículo 1594 CC no requiere la concurrencia de los requisitos necesarios para la resolución contractual; en particular, del previo incumplimiento del contratista. Así lo reflejan, sin carácter exhaustivo, las sentencias del Tribunal Supremo de 13 de mayo de 1993 (RJ 1993/3546), 4 de febrero de 1997 (RJ 1997/ 675), 9 de marzo de 1999 (RJ 1999/1408), 18 de julio de 2000 (RJ 2000/6811), 31 de mayo de 2001 (RJ 2001/3449) y 25 de noviembre de 2002 (RJ 2002/10275).

\section{El supuesto de hecho que permite acudir al desistimiento unilateral}

Hemos visto cómo, salvo que se haya pactado otra cosa (la mayoría de la doctrina reconoce la posibilidad de limitar, con base en la autonomía de la voluntad, las causas que permiten su ejercicio), el desistimiento puede ser libremente ejercitado por el dueño de la obra. Se trata, en este sentido, de una declaración abstracta, pues no requiere expresión de la causa que lleva a actuar de ese modo; es más: ni siquiera exige concurrencia de causa alguna.

No obstante, no será extraño que el comitente que sopesa la conveniencia de paralizar la obra se plantee actuar de acuerdo con el artículo 1594 CC o, de modo aparentemente distinto, provocar la resolución contractual, para lo que le bastaría 
con incumplir sus más elementales obligaciones, forzando así al contratista a acudir al artículo 1124 CC.

Nótese que el planteamiento de esta alternativa únicamente tiene sentido si las consecuencias resarcitorias derivadas de cada opción (desistimiento o resolución) son distintas, algo que todavía no hemos analizado pero que, como hemos visto, consta reiteradamente declarado por los Tribunales españoles.

Pues bien, dejando para más adelante esta última cuestión, los Tribunales han venido asimilando al desistimiento ciertos comportamientos que, más que constituir una infracción contractual, reflejan una más profunda y global voluntad de no proseguir con la obra. Bien pudiera haber constituido obstáculo para este proceso el tan reiterado carácter excepcional del artículo 1594 CC; no obstante, como advierte CADARSO PALAU (9), nuestros Tribunales han ido dejando de prestar tanta atención a la naturaleza de la norma para centrarse en sus efectos. Buen ejemplo de ello es la sentencia del Tribunal Supremo de 15 de diciembre de 1981 (RJ 1981/5158), que manifestó que, con independencia del carácter otorgado al artículo 1594 CC, lo relevante es la determinación de sus efectos.

En cuanto a las conductas que, por su gravedad, han sido equiparadas al desistimiento, debe partirse de la manifestación general contenida en la sentencia del Alto Tribunal de 13 de mayo de 1993 (RJ 1993/3546), que, considerando que el desistimiento también puede ser tácito, afirmó que en esa categoría "cabría incluir la derivada de aquellas situaciones que demuestran, por su equivalencia, una evidente intención o voluntad de impago de la obra".

Ejemplo de conducta equiparada al desistimiento es la injustificada expulsión del contratista, contemplada en la sentencia del Tribunal Supremo de 20 febrero 1993 (RJ 1993/1003): “(...) probado por admitido, que los demandados expulsaron de la obra al actor, está fuera de duda que la reclamación actora, en el punto relativo al beneficio industrial, tiene acogida en el art. 1594 del Código Civil". En el mismo sentido, la sentencia de la Audiencia Provincial de La Rioja de 4 de enero de 2001 (JUR 2001/113645), en un caso en que, a pesar de que la promotora comunicó la resolución, lo hizo después de recibida provisionalmente la obra e impidiendo la entrada al contratista para ejecutar los repasos; puede leerse "(...) el impedir el acceso a la misma, equivale al desistimiento unilateral del dueño de aquella con anterioridad a su recepción definitiva, siendo a continuación cuando la actora resuelve el contrato mediante comunicación notarial, resolución posterior al desistimiento y aceptada de contrario, pero cuando ya la demandada había renunciado al cumplimiento íntegro del contrato". 


\section{El resarcimiento contemplado en el artículo $1594 \mathrm{CC}$}

Obviando el estudio de otras consecuencias del desistimiento unilateral (por ejemplo, la extinción del contrato o la necesidad de inmediata entrega de la obra por el contratista), nos centramos en el resarcimiento que este tiene derecho a percibir, consistente, según el precepto, en "todos sus gastos, trabajo y utilidad que pudiera obtener de ella [de la obra]".

Analicemos cada uno de esos conceptos, para posteriormente plantearnos si su resarcimiento tiene un alcance distinto al que derivaría del artículo 1124 CC.

\section{Gastos y trabajo}

Las cuestiones analizadas serán las siguientes: (a) si el resarcimiento de los gastos y trabajos debe ajustarse a los precios previstos en el contrato; (b) si, específicamente en los contratos por precio alzado, la indemnización debe ser proporcional a la obra ejecutada, sin alterar la referencia del precio total previsto, y (c) si esa indemnización únicamente comprende los gastos y trabajos ya incorporados a la obra.

(a) Respecto a si el resarcimiento debe ajustarse a los precios previstos en el contrato, la respuesta ha sido mayoritariamente negativa, de modo que los Tribunales vienen concediendo la indemnización que abarque el coste real y actual de los gastos y trabajos, prescindiendo del contrato y atendiendo a la correspondiente prueba pericial. Se percibe aquí, pues, una clara diferencia con lo previsto en el artículo 1595 CC, que, para el caso de fallecimiento del contratista, señala que la parte ejecutada se abonará "a proporción del precio convenido".

En el sentido apuntado, por ejemplo, se pronuncia la sentencia del Tribunal Supremo de 15 de diciembre de 1981 (RJ 1981/5158): "(..) sobrevenido el desistimiento de la parte demandada de la prosecución y finalización de la obra, tal circunstancia no puede imposibilitar ni mermar el derecho del actor a ser indemnizado de los gastos habidos hasta entonces, los cuales, a falta de acuerdo entre los litigantes, deben ser concretados por un experto conocedor de estas cuestiones, quien ha de valorar lo realmente hecho para poder así determinar el importe de lo indemnizable, y ello con independencia de lo inicialmente estipulado".

En idénticos términos, la sentencia del mismo Tribunal de 5 de mayo de 1983 (RJ 1983/2624): "(...) debiendo cuantificarse las cantidades e indemnizar a través de la oportuna prueba pericial, determinante de las obras realizadas y de su real importe, al margen del condicionado del contrato de ejecución de obra". 
Asimismo, citamos la sentencia del Tribunal Supremo de 8 de octubre de 1987 (RJ 1987/6766), que -analizando un caso de ejecución de obras de urbanización, en la que la contraprestación consistía en la mitad del precio resultante de la venta de ciertas parcelas- afirma: "(...) se aplica (en el quinto) con indudable acierto a investigar el montante de la indemnización acreditada "dejando al margen, como procede hacer, el condicionado del contrato (en especial, la cláusula relativa a la contraprestación dineraria por la ejecución de la obra contratada)». La indemnización la rige (sexto considerando) por "el importe total de las obras ejecutadas» (...) puntualizándose en torno a los conceptos de la indemnización debida al mismo que por "gastos» y "trabajos" han de entenderse los originados y realizados en la parte de la obra ejecutada, así jornales, honorarios y materiales invertidos".

Sin embargo, no falta alguna resolución en sentido contrario; muy particularmente, la sentencia del Tribunal Supremo de 7 de octubre de 1986 (RJ 1986/5330), que manifiesta debe atenderse a las previsiones de las partes: "(...) quiérese decir que por ese hecho ya venía constreñida a su abono, por preverlo el contrato en su cláusula cuarta, ya que de otra suerte se produciría un enriquecimiento injusto, con grave detrimento del equilibrio negocial, aparte de que los principios informantes de este singular contrato (...) exigen que el dueño de la obra satisfaga el precio de la ejecutada conforme a los módulos y previsiones convenidos".

(b) La indemnización, específicamente, en los contratos de obra por precio alzado. A pesar de alguna sentencia aislada (señaladamente, la del Tribunal Supremo de 22 de noviembre de 1974 -RJ 1974/4376-), los Tribunales mantienen aquí el mismo principio, de modo que el resarcimiento no tiene por qué coincidir con el resultado de proyectar, sobre el precio cerrado total, la parte de la obra efectivamente ejecutada.

Reflejo de esa regla es la sentencia del Tribunal Supremo de 15 de diciembre de 1981 (RJ 1981/5158) que, si bien afirma que en principio la valoración de los daños debe llevarse a cabo en proporción al precio total, considera que, de acreditarse que los costes son superiores al resultado de esa regla de tres, deben ser resarcidos. Dice la sentencia: "(...) si la ejecución fue bajo un precio alzado (...), si la parte proporcional del mismo correspondiente a la parte de obra ejecutada no cubriere los gastos realmente originados y el importe de los trabajos efectivamente incorporados, no podría utilizarse sin vulnerar el designio del art. 1594 del C. Civ., que, dicho sea una vez más, pasa por la más perfecta indemnidad del contratista, para efectuar el cálculo de la indemnización acreditada por éste y que, entendiéndolo de otro modo, dejaría de serlo partiéndose de aquel precio y fijando ésta a proporción de la obra ejecutada". 
En los mismos términos que la anterior resolución se pronuncia la sentencia del Tribunal Supremo de 8 de octubre de 1987 (RJ 1987/6766): "(...) aún existiendo precio alzado (...), prescindiéndose del precio si la parte proporcional correspondiente a la parte de obra ejecutada no cubriere los gastos realmente originados y el importe de los trabajos efectivamente incorporados, se efectúa según estos gastos e importes reales el cálculo de la indemnización por cuanto la facultad del artículo 1594 pasa por la más perfecta indemnidad del contratista (...)".

En la doctrina, algunos autores como SIRVENT GARCÍA se limitan a hacerse eco de las sentencias transcritas, afirmando pues que deberá estarse al precio pactado, salvo que el coste real sea superior (10). Igualmente, CARRASCO PERERA: "(...) la existencia de precio alzado no significa que sólo deba reembolsarse lo ejecutado en proporción a la cuantía fijada, pues la exigencia de indemnidad del contratista hay que salvarla siempre, por lo que, aun a costa de prescindir del precio alzado, el reembolso debe cubrir los gastos realmente originados y el importe de los trabajos efectivamente incorporados" (11).

Esta línea es criticada por CADARSO PALAU: de un lado, porque, procediendo de este modo, pudiera suceder que el contratista recibiera, como indemnización de la parte de la obra, más que lo que hubiera percibido de haberla terminado, contraviniéndose así la protección del dueño pretendida por la norma. De otro lado, porque la comparativa entre parte proporcional del precio y gasto real se contempla únicamente en una dirección (si el coste es superior al precio, debe indemnizarse el primero), sin plantearse la posibilidad contraria: que el coste sea inferior a la parte proporcional del precio (12).

Por nuestra parte, nos limitamos a dejar constancia que la solución aplicada por nuestros Tribunales no deja de ser consecuencia natural de la jurisprudencia, más amplia, de acuerdo con la que, a pesar de pactarse un precio cerrado, debe abonarse el coste de la mayor obra ejecutada (por todas, sentencias del Tribunal Supremo de 31 de octubre de 1998 -RJ 1998/8165-, 3 de noviembre de 1998 -RJ 1998/8735-, 13 de octubre de 1999 -RJ 1999/7424- y 20 de marzo de 2001 - RJ 2001/4742-).

Es más: esta más amplia doctrina, por muchos criticada -el contratista es un experto, que debe ser capaz de ajustar el precio al resultado que se le exige-, adquiere más sentido en caso de desistimiento del promotor, hecho que sí puede provocar el súbito desvanecimiento de los cálculos económicos del constructor.

(c) Respecto del tercero de los puntos anunciados -si la indemnización debe limitarse a los gastos y trabajos ya incorporados a la obra-, es postura pacífica que, lejos de ello, aquella abarcará también cualquier otro gasto en que haya incurrido el contratista en contemplación a la obra. 
Así lo manifiesta, por ejemplo, la sentencia de la Audiencia Provincial de Asturias de 10 de septiembre de 1998 (AC 1998/6532), que como consecuencia otorga el resarcimiento de los trabajos preparatorios para la obra, entre los que se incluía determinado estudio financiero acerca de la viabilidad de una solicitud de crédito.

El mismo criterio recoge la sentencia de la Audiencia Provincial de Salamanca de 20 de octubre de 2000 (JUR 2001/44432), para obligar a quien desistió a resarcir los gastos derivados de la elaboración de unos catálogos que habían sido ya aceptados por la propiedad.

Asimismo, la sentencia de la Audiencia Provincial de Murcia de 24 de febrero 2003 (JUR 2003/196681), recordando el mencionado principio general - "(...) el concepto global de gastos se comprenden todos los desembolsos que el contratista haya efectuado para el pago de bienes o servicios que, aunque no estuvieran incorporados a la obra, se hubieran hecho en atención a la misma"-, impone la indemnización de ciertas obras de fontanería, ya preparadas y cuya ejecución se frustró por el súbito desistimiento del dueño.

En similar sentido, las sentencias de la Audiencia Provincial de Barcelona de 13 de octubre de 2000 (JUR 2001/23047), y de la Audiencia Provincial de Madrid de 21 de junio de 2004 (JUR 2004/235563).

\section{El beneficio que el contratista pudiera obtener de la obra}

En esta sede, la cuestión más estudiada es si dicho beneficio debe ser cuantificado en el 15\% generalmente considerado como beneficio industrial, materia sobre la que los Tribunales españoles oscilan (siempre a falta de pacto) entre la aplicación de ese porcentaje sin necesidad de prueba -así, por ejemplo, DEL ARCO TORRES y PONS GONZÁLEZ: (13)-, y la consideración de que aquel debe ser coherente con las circunstancias económicas del caso.

Buena muestra de la aplicación del mencionado porcentaje del 15\% es la sentencia del Tribunal Supremo de 13 de mayo de 1993 (RJ 1993/3546), que afirma que aquel debe considerarse sin necesidad de actividad probatoria, por ser costumbre generalizada y notoria (artículo 1.3 CC, artículo 2 del Código de Comercio y 281.4 de la Ley de Enjuiciamiento Civil española). Dice esta sentencia: "(...) respecto a la base fáctica de la utilidad del $15 \%$ de la obra (...), su estimación es de uso generalizado al concurrir el supuesto al que se refiere el art. 1594 (...), sin que su existencia y exigencia, en razón a su específica índole y su fijación con arreglo al generalizado criterio estimativo del $15 \%$ del precio convenido, dependa de ninguna actividad probatoria practicada sobre la realidad de los daños y perjuicios sufridos por el contratista". 
De modo similar, la sentencia del mismo Tribunal de 15 de octubre de 1992 (RJ 1992/7821), que se pronuncia en los siguientes términos: "(...) en ausencia de pacto sobre beneficio industrial en la contraprestación de obras y servicios, los Tribunales han estimado en el tráfico negocial el quince por ciento del presupuesto convenido, que es algo superior al interés incrementado del dinero a efectos judiciales. Y es en el uso generalizado o la costumbre, en que se sigue manteniendo en muchos contratos de obra, en donde se cuantifica en el porcentaje correspondiente el beneficio industrial de la ejecución de la misma sobre los materiales aportados y las subcontratas convenidas".

Finalmente, la sentencia de 13 de mayo de 1983 (RJ 1983/2822) aplica el beneficio del $15 \%$, a pesar de que el tenor del contrato resultaba dudoso, pues diferenciaba un concepto de imprevistos del 1\%, otro de dirección del 5\% y, finalmente, un estricto beneficio industrial de 9\%. La resolución, considerando que los tres conceptos deben quedar conceptualmente embebidos en el beneficio industrial, adiciona los porcentajes y fija aquel en el 15\%. Puede leerse: "(...) interpretado erróneamente el art. 1594, del C. Civ., al cifrar la indemnización que correspondía al contratista por aplicación del últimamente citado precepto en el 15 por 100 atribuible al llamado "beneficio industrial», siendo así que, según aduce, con la O. de 18 mayo 1960 en tres partidas correspondiente al 1 por 100 de imprevistos, al 5 por 100 de dirección de obra y al 9 por 100 de estricto beneficio industrial, entendiendo por ello que al no haberse realizado la obra contratada respecto a cuatro depósitos la única cantidad de procedente abono al contratista era la significada por el 9 por 100 del presupuesto de ejecución y no la del 15 por 100, acogiendo como criterio estimativo el generalizado que da como presupuesto una utilidad del 15 por 100 con carácter neto".

No obstante, como se ha anticipado, otras resoluciones afirman que la determinación del beneficio industrial en el $15 \%$ es meramente indicativa, y sujeta por tanto a su eventual coherencia con las circunstancias económicas y sociales. En esta línea, afirma la sentencia del Tribunal Supremo de 17 de octubre de 1996 (RJ 1996/7115): "El porcentaje del 15\%, que pretenden se aplique los recurrentes, no procede su acogida (...), no se ha establecido la utilidad del $15 \%$ como un porcentaje fijo y no sometido a las circunstancias económico-sociales de los tiempos, al tratarse de un uso general (...), cambiante y acomodado a cada realidad histórico-social". De modo similar, la sentencia del Alto Tribunal de 28 de julio de 2000 (RJ 2000/6202) indica que, con prevalencia sobre dicho porcentaje, debe atenderse a la prueba efectivamente practicada: "(...) la sentencia recurrida, independientemente de abono de gastos y pago ya hecho de jornales, tiene presente, para llegar a fijar la indemnización por utilidad que estima adecuada para la contratista el precio de la obra y el porcentaje generalizado del $15 \%$ sobre el mismo, que no puede ser más que indicativo. En estas determinaciones, al igual que en la valoración de las pruebas, la facultad corresponde al juzgador de instancia como cuestión de hecho que es (...) y ha de prevalecer al no haberse acreditado que incide en error". 
Más reacia incluso a la aceptación de porcentaje alguno se muestra la sentencia del Tribunal Supremo de 25 de abril de 2003 (RJ 2003/3546), al señalar, no ya la preferencia de la prueba sobre costumbre alguna, sino la necesidad de estar siempre a dicha prueba, sin dar por supuesta la existencia de uso alguno: "(...) habrá de estarse a lo pactado, o al cálculo con arreglo a los márgenes o elementos que figuren en el contrato (Sentencia 30 mayo 1993 SIC), y, en su defecto, la determinación es una facultad que corresponde al juzgador de instancia como una cuestión de hecho (S. 28 julio 2000)".

\section{El resarcimiento vía artículo $1594 \mathrm{CC}$, ¿es distinto al que derivaría del 1124 CC?}

Analizados los conceptos resarcitorios contemplados en el artículo 1594 CC, surge inevitablemente la siguiente cuestión: ¿concede ese precepto una indemnización distinta a la que correspondería como consecuencia de una simple resolución contractual? ¿O concede una indemnización menor, bajo el entendimiento de que, dado que el dueño goza del privilegio de desistir, este quedaría diluido si no se le permitiera abonar un resarcimiento limitado? O, incluso, ¿prevé una indemnización superior a la que resultaría de las normas generales, precisamente para compensar la excepcionalidad de que una parte pueda libremente dejar sin efecto un contrato?

Pasamos a analizar esta cuestión:

a) La solución aparente: en cuanto pretende la indemnidad del contratista, el desistimiento acarrea la misma indemnización que resultaría de la aplicación de las reglas generales de responsabilidad contractual.

En efecto: muchas de las sentencias citadas al analizar los conceptos objeto de resarcimiento (gastos, trabajos y beneficio) afirman que la extensión de la indemnización debe ser aquella que logre la indemnidad del contratista, esto es: aquella que, apartando mentalmente el acaecimiento del desistimiento, consiga colocarle en la misma situación en que se hallaría si la obra hubiese finalizado correctamente.

En este sentido se pronuncia la ya invocada sentencia del Tribunal Supremo de 8 de octubre de 1987 (RJ 1987/6766), que, abandonando el estudio de la naturaleza del desistimiento unilateral, habla de "cierta unanimidad en la determinación de sus efectos, presidida por la idea de la indemnidad del contratista". En iguales términos, las sentencias del Tribunal Supremo de 10 de marzo de 1979 (RJ 1979/858) -que habla de "dejar indemne al contratista, es decir, a que el patrimonio de este no sufra menoscabo alguno como consecuencia de aquel desistimiento"-, 15 de diciembre de 1981 (RJ 1981/5158) -que impone el resarcimiento de "todas las utilidades que hubieran podido obtenerse en la obra en 
su totalidad, y no tan solo en la parte de la misma ya ejecutada"-, 7 de octubre de 1982 (RJ 1982/5543) y 19 de febrero de 2010.

No obstante, la sentencia más clara al respecto es la del Tribunal Supremo de 13 de mayo de 1993 (RJ 1993/3546), única de la que tengo conocimiento que afirma con nitidez que la resolución y el desistimiento desencadenan exactamente las mismas consecuencias resarcitorias, advirtiendo que, mediante la comprensión de las "utilidades", el artículo 1594 CC abarca también el resarcimiento del lucro cesante. Declara esta resolución: "si la calificación de la Sala de instancia acerca de la conducta del dueño de la obra (...) fuere, en lugar de una manifestación de desistimiento, la de un incumplimiento, se llegaría a la misma conclusión, dado que los daños y perjuicios probados serían solo el beneficio industrial, con lo que se desembocaría en igual resultado, toda vez que los hechos obligarían al Tribunal a dar respuesta por el cauce del art. 1124, máxime, cuando el resarcimiento de dicho precepto comprende tanto al "damnum emergens", como el "lucrus cesam», concepto este segundo que engloba la "utilidad» de que habla el 1594".

En términos similares, CARRASCO PERERA, que afirma que el desistimiento unilateral analizado "no constituye una facultad que exceptúe completamente [el significado del adverbio se nos escapa] el principio de vinculación contractual (arts. 1091, 1256 y 1258 CC), pues la "indemnización" debe cubrir totalmente el interés contractual positivo del contratista, de tal forma que, a pesar del desistimiento, este quede indemne" (14).

De hecho, la misma consideración fue realizada, mucho tiempo atrás, por el propio GARCÍA GOYENA, a la vista del anterior artículo 1535: "Ningún perjuicio se irroga por el artículo al arquitecto o empresario, pues se da todo lo que podría tener después de concluida la obra".

b) Esbozo de la diferencia entre ambos regímenes: el artículo 1594 CC prevé una indemnización que opera con abstracción del elemento intencional (culpa o dolo) a los efectos del artículo 1107 CC.

La cuidadosa lectura de las sentencias (muchas de las cuales, antes citadas) que enfatizan el conocido principio de que los motivos del desistimiento son irrelevantes, mueve a pensar -si bien ello no puede darse por cierto- que se está sugiriendo lo siguiente: el resarcimiento contemplado en el artículo 1594 CC no se verá agravado por un comportamiento tal que, de acuerdo con el régimen general de la responsabilidad civil, constituiría dolo, y obligaría a resarcir, no sólo los daños previsibles al contraer la obligación y necesaria consecuencia del incumplimiento, sino, yendo más allá, "todos los que conocidamente se deriven de la falta de cumplimiento de la obligación" (artículo 1107 CC). 
Para atisbar este entendimiento (cuya formulación expresa sería, en cualquier caso, de agradecer) resulta de ayuda la sentencia del Tribunal Supremo de 29 de septiembre de 2005 (RJ 2005/8892), que a la referida irrelevancia de los motivos añade que, en el marco del artículo 1594 CC, no cabe invocar circunstancias que tendrían relevancia en el ámbito del artículo 1124 CC. Dice esta resolución: "(...) el derecho del contratista a percibir la indemnización a que se refiere el art.1594 del Código Civil, no depende en absoluto de los móviles o razones que hayan inducido al propietario del terreno a desistir (...). Las consecuencias indemnizatorias (...), sin que para su cuantificación puedan tenerse en cuenta circunstancias relativas al cumplimiento o incumplimiento por los contratantes de sus obligaciones, susceptibles de ser invocadas al amparo del art. 1124 del Código Civil".

Ciertamente, a esta tesis podría objetarse que, entendido el dolo como conciencia de que se está incumpliendo una obligación, no requerido de específica voluntad de perjudicar o "animus nocendi" (analizando el mencionado artículo 1107 CC, dice la sentencia del Tribunal Supremo de 30 de noviembre de 1999 -RJ 1999/8439-: "El Código Civil no da una noción de dolo en el incumplimiento de la obligación (...), no siendo preciso para ello la voluntad de dañar o "animus nocendi", siendo bastante la voluntad consciente de incumplir") quien desiste siempre incurriría necesariamente en dolo, lo que privaría de sentido a la anterior explicación.

La respuesta que, a mi juicio, merece este obstáculo, se contiene en el apartado siguiente.

c) El alcance resarcitorio del artículo 1594 CC sí viene modulado por el reproche jurídico que merezca el comportamiento del comitente.

Lo expuesto impone adaptar el concepto de dolo al supuesto de hecho que estamos analizando, lo que considero puede hacerse como sigue: el desistimiento unilateral es simplemente culposo cuando concurren circunstancias que imponen ese proceder o, cuando menos, le otorgan razonabilidad (entorno económico, aparición de circunstancias sobrevenidas, etc.), y, además, se ejercita de acuerdo con las exigencias de la buena fe (artículo 7.1 CC): particularmente, informando con antelación al contratista de la posibilidad de desistimiento.

Por el contrario, el desistimiento es doloso si no se practica de acuerdo con tales parámetros: por ejemplo, cuando la causa reside en la comodidad o capricho del dueño, o en la localización de mejores alternativas económicas; también cuando, cualquiera que sea su origen, es comunicado súbitamente al contratista.

Me niego, pues, a entender que el artículo 1594 CC contemple con carácter general un resarcimiento más limitado que el derivado del régimen general de responsabilidad contractual -en primer lugar-, y que las motivaciones subjetivas 
que Ilevan al desistimiento sean perfectamente irrelevantes con vistas a determinar la indemnización que deberá soportar: tales elementos pueden ser estériles en relación con el efecto consistente en la extinción del contrato de obra (que sí tendrá lugar en cualquier caso, aun cuando el comportamiento del promotor merezca el máximo reproche), pero no a efectos del resarcimiento que deberá imponérsele.

Resultaría sencillamente inaceptable que un desistimiento caprichoso, e incluso ejercitado con la intención de causar daño al constructor, no conllevara mayor indemnización que el Ilevado a cabo por causas y mediante métodos distintos.

Nótese que los Tribunales ya han tenido en cuenta el ánimo del comitente en el marco del artículo 1594 CC: concretamente, para determinar si nos hallamos ante el supuesto de hecho en él contemplado. Como hemos comprobado, el ánimo del sujeto permite, en ocasiones, asimilar al desistimiento aparentes incumplimientos. Pues bien, del mismo modo ese ánimo debe contemplarse para fijar la indemnización a abonar por el promotor.

A este argumento, derivado de un adecuado entendimiento sistemático de la responsabilidad civil, puede aun añadirse otro: el artículo 1594 CC, al tratar de la indemnización derivada de la utilidad de la obra, contiene el pretérito del subjuntivo "pudiera", expresión sobradamente apta para, caso de que el desistimiento no se ejerza de acuerdo con la descrita buena fe, dar cabida a un resarcimiento de mayor proyección temporal, e incluso de daños meramente potenciales y cuya relación de causalidad se presente, hasta cierto punto, debilitada.

De este modo debe, por tanto, interpretarse el precepto: la tan reiterada irrelevancia de los motivos del propietario debe entenderse circunscrita a que su declaración de voluntad conllevará, en cualquier caso, la extinción del arrendamiento. Aquí topamos, efectivamente, con una especialidad respecto del régimen general de las obligaciones, en el que esa forma de actuar otorgaría al contratista, en primer término, el derecho a reclamar el cumplimiento "in natura" (artículo 1098 CC) y, por tanto, exigir la continuación de la obra.

Cosa bien distinta es la indemnización a cargo del comitente, modulable en atención a su comportamiento y que, a salvo la adaptación que exige el concepto de dolo, en nada diverge del régimen general.

\section{Bibliografía}

(1) Florencio García Goyena, "Concordancias, motivos y comentarios del Código Civil español", reimpresión de la edición de Madrid, 1852, realizada por LACRUz BERDEjO, Zaragoza, 1974, página 803. 
(2) Fernando de la Cámara Mingo, "Derecho civil básico. Los contratos relacionados con la construcción", en "Tratado práctico del derecho referente a la construcción y a la arquitectura", tomo IV, Madrid, 1964, página 639.

Concepción Rodríguez Marín, "El desistimiento unilateral (como causa de extinción del contrato)", editorial Montecorvo, Madrid, 1991, páginas 333 y 334.

(3) Luigi ABello, "Tratatto della locazione", volumen IV, Nápoles-Turín, 1922, página 877.

(4) Vito ManginI, "Il contratto di appalto", en "Giurisprudenza sistematica civile e commerciale", Turín, 1972, página 290.

(5) Jorge Sirvent García, "El desistimiento unilateral del comitente en el contrato de obra", Revista de Derecho Patrimonial, no 8, Madrid, 2002, páginas 105 a 128.

(6) Fernando de la Cámara Mingo, op. cit., página 639. José Puig Brutau, "Fundamentos de Derecho Civil", tomo II, volumen 20, editorial Bosch, Barcelona, 1982, página 478.

(7) Raymond Théodore Troplong, "Droit civil expliqué", París, 1840, nº 1030, páginas 244 y 245.

(8) José Manresa Navarra, "Comentarios al Código Civil español", tomo X, volumen II, Madrid, 1969, página 729.

(9) Juan Cadarso Palau, "El desistimiento del dueño en el contrato de obra y la indemnización al contratista", Poder Judicial, n 10, 1987, página 97.

(10) Jorge Sirvent García, op. cit., página 120.

(11) Ángel Carrasco Perera, "Derecho de la Construcción y la Vivienda", editorial Dilex, Madrid, 1998, página 224.

(12) Juan Cadarso Palau, op. cit., páginas 98 a 100.

(13) Miguel Ángel del Arco Torres y Manuel Pons González, "Derecho de la Construcción. Aspectos administrativos, civiles y penales. Adaptado a la Ley de Ordenación de la Edificación", editorial Comares, Granada, 2003, página 436.

(14) Ángel Carrasco Perera op. cit., página 223. 


\title{
LAS VIRTUDES JUDICIALES Y LA NOVELA UN JUEZ RURAL DE PEDRO PRADO: APUNTES PARA UN PROBLEMA IDEOLÓGICO
}

THE JUDICIAL VIRTUES AND THE NOVEL A RURAL JUDGE BY PEDRO PRADO. NOTES FOR AN IDEOLOGICAL PROBLEM

Claudio Agüero San Juan

Fecha de recepción: 4 de mayo de 2010.

Fecha de aceptación: 5 de junio de 2010.

\section{Resumen}

El artículo revisa el problema de la evaluación moral de la judicatura a partir de las relaciones entre Derecho y Literatura. Desarrolla la posición de Alisdair Maclntyre sobre las virtudes y revisa cómo la novela chilena Un juez rural de Pedro Prado puede considerarse una forma de expresión del punto de vista macintyriano. Finaliza, mostrando cómo cualquier evaluación moral del rol judicial es, a fin de cuentas, la manifestación de una ideología.

Palabras clave: MacIntyre, virtudes judiciales, Un juez rural.

\begin{abstract}
The article reviews the problem of moral assessment of the judiciary from the relationship between law and literature. Develop Alisdair Maclntyre's position on the virtues and reviews how the Chilean novel A rural judge of Pedro Prado can be considered a form of expression macintyriano point of view. End, showing how any moral evaluation of the judicial role is, after all, the manifestation of an ideology.
\end{abstract}

Key words: Maclntyre, judicial virtues, A rural judge.

Oliver Wendell Holmes

Abogado, Licenciado en Ciencias Jurídicas de la Universidad Católica de Temuco, Magíster en Educación, Universidad de La Frontera.

Académico Escuela de Derecho, Universidad Católica de Temuco

Mail: aguero@uct.cl 


\section{Introducción}

Según François Ost es posible comprender la relación entre el Derecho y la Literatura de tres formas: el Derecho de la Literatura, el Derecho como Literatura y el Derecho en la Literatura. La primera, se interesa por el estudio de la libertad de expresión y de la censura como fenómenos jurídicos asociados a la publicación de libros como, Werther, Madame Bovary o Los versos satánicos. La segunda, analiza las dimensiones retórica y narrativa del discurso jurídico con las herramientas propias de la crítica literaria y del análisis narratológico. La tercera, estudia cómo las obras literarias recepcionan ciertas concepciones normativas -jurídicas y morales- sobre la Justicia, Ios Derechos Fundamentales o el Poder Político ${ }^{1}$. El presente trabajo se integra a esta última forma de comprender la relación entre el Derecho y la Literatura, mediante el análisis de la novela Un juez rural del escritor chileno Pedro Prado. Su objetivo es proponer que 'la persecución de la prudencia' como virtud -en su versión comunitarista postulada por Maclntyre ${ }^{2}$ - es la matriz de la novela y la forma más adecuada para comprender la obra de Prado de forma unitaria, ya que permite enfrentar a la interpretación tradicional de la crítica literaria nacional que ha visto en ella una historia fracturada en dos fragmentos divididos por la renuncia al cargo de juez del protagonista $^{3}$.

Mi hipótesis es doble, por un lado afirma que la comprensión comunitarista de la virtud de la prudencia se expresa de forma alegórica en novela ${ }^{4}$-cuestión que ha sido omitida por la crítica nacional-, y por otro, postula que la revisión de obras literarias permite, al lector atento, captar las ideologías sobre la administración de justicia que circulan en la sociedad. Para falsear esta hipótesis mi argumentación procederá en tres pasos: primero desarrollaré el modelo de las virtudes según Maclntyre mostrando el rol de la prudencia; luego, analizaré la búsqueda de la prudencia en la novela interpretando algunos acontecimientos de la historia y la construcción del personaje protagónico como manifestaciones de la idea de 'estructura narrativa de la vida' del comunitarismo macintyriano. Finalizaré con unas palabras de cierre, las que se concentrarán en formular el carácter ideológico de la crítica moral de la tarea judicial.

François Ost, "El reflejo del Derecho en la literatura", Revista Doxa de Teoría y Filosofía del Derecho 29 (2006), pp. 334-336.

2 Alasdair Maclntyre, Tras la virtud (Barcelona: Crítica, 1987).

3 Julio Arriagada y Hugo Goldsack, "Pedro Prado, un clásico de América". Revista Atenea de la Universidad de Concepción (Chile) 321, 322, 323, 324 (1952)

4 Gerald Genette, "El discurso del relato", en Figuras III (Barcelona: Lumen, 1986). 


\section{El modelo de las virtudes de Maclntyre}

En 1984, Alasdair Maclntyre publicó After Virtue (Tras la virtud), donde postuló que Occidente había perdido una visión ética coherente y sistemática sobre los problemas morales, debido al fracaso del proyecto ilustrado que intentó romper todos los fundamentos metafísicos explicando racionalmente los fenómenos sociales. Frente a esta crisis de la ética, Maclntyre propuso retomar la tradición aristotélico-tomista de las virtudes abandonando la ética kantiana de reglas universales para fundar un proyecto ético en tres conceptos: las 'prácticas sociales', la 'estructura narrativa de la vida humana' y la 'tradición moral'.

Maclntyre definió 'práctica social' como una actividad humana cooperativa, compleja y socialmente establecida, cuyo ejercicio permite que los practicantes logren bienes internos a la actividad según el modelo de excelencia que define al bien prácticamente y otros bienes externos a ella ${ }^{5}$.

Son bienes internos aquellos que pueden ser adquiridos por los practicantes solo mediante el ejercicio de la práctica en cuestión y cuyo logro favorece el florecimiento de toda la comunidad, mientras que, son bienes externos los que pueden ser adquiridos por el ejercicio de varias prácticas alternativas y que generan un beneficio exclusivo para su propietario. Según Maclntyre, los bienes internos se realizan a través de las virtudes pues el ejercicio de la virtud permite adquirir el bien y mejorar la actividad colaborativa de la comunidad a través del seguimiento del modelo de excelencia de la práctica, es decir, mediante la persecución del patrón de conducta que contiene las normas de evaluación del desempeño de los practicantes y que por ello define al buen practicante.

Con este concepto de 'práctica social', Maclntyre ofrece un primer acercamiento a la idea de virtud cuyas funciones son: mostrar la necesidad de las virtudes como formas de acceso a los bienes contenidos en las prácticas y hacer notar que las virtudes definen las relaciones entre las personas que comparten un propósito y un modelo de excelencia:

"Una virtud es una cualidad humana adquirida, cuya posesión y ejercicio tiende a hacernos capaces de lograr aquellos bienes que son internos a las prácticas y cuya carencia nos impide efectivamente el lograr cualquiera de tales bienes" ${ }^{\prime}$.

El segundo concepto es 'la estructura narrativa de la vida'. Siguiendo a Aristóteles, Maclntyre postuló que la búsqueda de la vida buena es la principal tarea de la ética. Para él, esta búsqueda otorga a la existencia humana la estructura de una narra-

Macintyre, Tras la virtud, p. 233.

$6 \quad$ Ibíd, p. 327. 
ción dramática en tres sentidos: primero, cada persona -al igual que un personaje literario- cuenta con una historia de vida, puede tomar ciertas decisiones y enfrenta un futuro que puede resultar exitoso o frustrado ${ }^{7}$. En segundo lugar, los problemas morales se consideran problemas narrativos, es decir, los actos morales solo pueden ser entendidos si se aprecian como acontecimientos que integran la historia de persona ${ }^{8}$. En tercer lugar, las personas -en tanto agentes morales- usan las narraciones como una estrategia epistémica y ética, mediante la cual aprenden el discernimiento moral y los roles sociales; ordenan, dan sentido y orientan sus decisiones, y comprenden las decisiones morales de otros ${ }^{9}$.

La tradición moral es el tercer concepto en el que Maclntyre apoya su teoría sobre las virtudes. Ella se define como el contexto dentro del cual se desarrolla la vida de las personas. La vida buena solo se logra mediante las prácticas sociales y ellas solamente pueden comprenderse en el marco de la tradición moral de la comunidad. La persona (para Maclntyre) es inseparable de su comunidad pues en ella se desarrolla su vida, se cultivan las virtudes, se aprende a ser agente moral y, en definitiva, se transita el camino hacia la excelencia moral ${ }^{10}$. La tradición es, entonces, la reunión de las historias de los individuos en una narración mayor que les otorga a ellas identidad comunal.

Esta forma narrativa de conseguir la perfección moral supone que la vida moral se concibe como una unidad. Si la vida moral tiene una 'estructura narrativa' a nivel personal y colectivo, las personas son, al mismo tiempo, hijos, padres, ciudadanos y profesionales. Por ello, sus acciones no pueden ser aisladas (posición defendida por la filosofía analítica), ni consideradas como manifestaciones de personajes diferentes (al modo de la filosofía existencialista) ya que esas opciones implican diluir el integridad telos del proyecto personal de vida buena, es decir, separar el concepto de lo bueno del hombre mismo. Este telos es la excelencia moral que permite comprender "lo que la vida buena para el hombre es" 11.

Aspirar a una vida virtuosa es buscar tener una existencia digna de ser narrada, y esta persecución -en tanto inherente a la naturaleza humana- impone que la 'estructura narrativa de la vida' gire en torno al valor de la prudencia entendida como phronesis (EN 1138b25) ya que, paradójicamente, el hombre siendo un ser racional es, al mismo tiempo, un ser falible. Tal como señala De la Torre:

"La prudencia es la clave de todas las virtudes. Sin ella no es posible ser virtuoso (sí obediente a la norma). Un hombre puede tener excelentes principios,

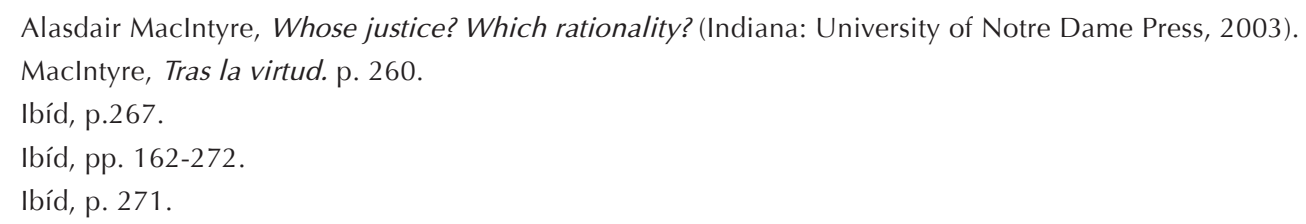


pero no actuar de acuerdo con ellos [...] La prudencia supone captar el verdadero telos del hombre y saber los casos en que hemos fracasado" 12.

Teniendo estas ideas a la vista, Maclntyre define las virtudes como:

"aquellas disposiciones que no sólo mantienen las prácticas y nos permiten alcanzar los bienes internos a las prácticas, sino que también nos sostienen en el tipo pertinente de búsqueda de lo bueno, ayudándonos a vencer los riesgos, peligros, tentaciones, y distracciones que encontremos y procurándonos creciente auto-conocimiento y creciente conocimiento del bien" ${ }^{13}$.

De este modo, Maclntyre presenta una crítica al individualismo epistemológico y a la modernidad racionalista ilustrada porque las virtudes no pueden ser alcanzadas individualmente debido a que las 'prácticas sociales' son siempre comunales. Así, es necesario que las personas se eduquen en la virtud de la prudencia y que se orienten en la tradición moral de la comunidad para que puedan lograr la excelencia moral.

\section{La novela}

La historia de la novela cuenta eventos de la vida del arquitecto Esteban Solaguren, que transcurren en poco más de dos meses en un tiempo y lugar parcialmente indefinidos. La secuencia de los acontecimientos permite apreciar una diégesis lineal compuesta de cuatro partes bien definidas: presentación del personaje y de su contexto, actuación como juez del protagonista, renuncia al cargo, y la narración de aspectos psicocognitivos del protagonista en los últimos capítulos de la novela.

Como he dicho más arriba, esta estructura ha motivado a la crítica literaria nacional para postular que la renuncia divide la historia en dos. Sobre el particular, Arriagada y Goldsack han señalado:

"Es curioso advertir que todos, engañados por el título, vean en esta novela simplemente las peripecias jurídico-morales de un juez de subdelegación, en circunstancias de que ella consta de dos partes bien definidas: la primera, que ya conocemos en general, y una segunda que no guarda ninguna relación con aquélla y en la que Prado cuenta algunas experiencias psicológicas personales y de gran interés" 14 .

\footnotetext{
12 Francisco Javier de la Torre Díaz, Alisdair Maclntyre ¿un crítico del liberalismo? (Madrid: Dykinson, 2005), p. 215.

13 Maclntyre, Tras la virtud, p. 270.

14 Arriagada y Goldsack, "Pedro Prado, un clásico de América", p. 274.
} 
Si bien el título de la novela hace referencia a la tarea de administrar justicia, existen varias evidencias que permiten postular que la historia se construye en torno a una alegoría a las virtudes.

La caracterización fictiva del actuar judicial del protagonista, ubica a un arquitecto en un juzgado de subdelegación resolviendo los casos 'a conciencia' y permite que la diégesis se aleje de la realidad judicial chilena de la época. Esta distancia permite, en mi opinión, juzgar que la novela no es una obra realista o costumbrista pues, por una parte, la sustitución del trabajo arquitectónico por el trabajo judicial en conciencia parecer ser una alegoría del abandono de la ética kantiana basada en principios universales y la asunción de la ética comunitaria y, por otra parte, porque la ficción del actuar judicial 'a conciencia' no siendo posible en la realidad, posiciona simbólicamente a Solaguren por sobre el derecho positivo mediante su liberación de las obligaciones prototípicas que el juzgador tiene en los sistemas jurídicos liberales: interpretar la ley y valorar los medios de prueba.

Esta opinión se confirma si la construcción del personaje protagónico en su dimensión profesional y personal se entiende como una estrategia literaria para mostrar la tensión entre la ética kantiana propia en la urbanidad postilustrada y la tradición ética comunal propia de la ruralidad agraria. La ubicación de un arquitecto (profesión liberal propia de la ciudad) en la posición social de juez, es decir, evaluador de los comportamientos ajenos en una comunidad agraria, desarrolla, a mi juicio, la idea de autoridad moral del juzgador y de su necesaria integración con la vida de los justiciables, cuestión que parece quedar en evidencia en la tensión que el ejercicio de la judicatura provoca en el temperamento melancólico y socialmente retraído de Solaguren, quien solo consigue la tranquilidad emocional en la pintura, en sus paseos por el campo y en ciertos momentos de soledad. Así, la novela cobra unidad si se aprecia que la diégesis y las metadiégesis giran en torno a las virtudes y a los estados doxásticos (creer, dudar, etc.) del protagonista, donde la prudencia es mediador ético y epistémico porque la moralidad de las acciones se deriva de la moralidad de los estados internos del agente. Por ejemplo, al inicio de la obra, el narrador relata a propósito de un incidente entre Solaguren y sus hijos: "Solaguren volvía lentamente a su tranquilidad. Entristecido, sentíase injusto con sus hijos" (p. 10). Posteriormente, en una noche de insomnio, el soliloquio del protagonista se dirige a los principios del razonamiento expuesto en Xenofontes (sic) y exclama: "iRepugnante Ilegar y llegar a conclusiones satisfechas de sí, como si fuesen, en verdad, las últimas y definitivas!". Luego, el narrador nos cuenta: "Sentía con meridiana evidencia la insulsez de lo que leyera, y todas las leyes del pensamiento ofrecíansele de golpe, nítidas, brillando en una intuición total que las abarcaba por completo" (p. 38) ${ }^{15}$.

15 Pedro Prado, Un juez rural (Santiago: Editorial Universitaria, 1996). 
Estos fragmentos muestran la reflexión moral del protagonista, y la relación que la novela establece entre la reflexión ética y los estados emocionales. Las cavilaciones del protagonista evidencian entonces el rechazo del modelo de razonamiento práctico basado en reglas universales (representado simbólicamente por el libro de Xenofontes) y del cual derivan las ideas de deberes y derechos individuales ${ }^{16}$. Acoge, en cambio, la intuición moral como camino para la resolución de los problemas éticos que le presentan los casos judiciales.

Es el sentimiento de lo bueno lo que permite al protagonista el acceso a la plena comprensión de las virtudes en tanto bienes objetivos manifestados en la narratividad de la vida en comunidad. Por ello, al fallar el protagonista aprecia en las historias de vida de los personajes el ejercicio virtuoso (o no) de la práctica social que da forma a cada uno de los conflictos y valora la narración de lo ocurrido que realizan los justiciables libre de buscar pruebas sobre su verdad. De esta forma, la prudencia se convierte en la herramienta epistemológica que permite al juez comprender el rol de la virtud en el relato de cada caso.

Otra manifestación de la narratividad ética es el acto mismo de renuncia al cargo de juez. La imposibilidad práctica de valorar positivamente las virtudes de los justiciables (premiar las conductas) y la fuerza de las relaciones interpersonales y/o comunitarias operan en el protagonista como razones absolutas en sentido aristotéli$\mathrm{co}$, es decir, como razones que motivan con tal fuerza la decisión de renunciar que la reflexión y más aún la abstención de la acción implican, desde su subjetividad, la irracionalidad. Este compromiso con la virtud, propio del razonamiento aristotélico, se exhibe en las consecuencias que la narración de la madre del ladrón tiene en Solaguren, quien se muestra desesperado y confundido. La metadiégesis de su carta de renuncia muestra la tensión entre las tradiciones éticas (la kantiana y la aristotélica) presentes en la obra:

"Mi desesperación, señor Intendente, proviene de que no puedo aislar un individuo, el culpable, y castigarlo solo a él... Parece, señor Intendente, que nuestras leyes se basan en el concepto de individuo, y ese concepto se me hace sospechoso: un individuo que no limita ¿qué individuo es? Su cuerpo aislado nos engaña con su apariencia independiente, no puedo aislar un individuo, el culpable, y castigarlo solo a él... Parece, señor Intendente, que nuestras leyes se basan en el concepto de individuo, y ese concepto se me hace sospechoso: un individuo que no limita ¿qué individuo es? Su cuerpo aislado nos engaña con su apariencia independiente. ¿Sobre qué base fundar la verdadera justicia?" 17.

16 De la Torre Díaz, Alisdair Maclntyre ¿un crítico del liberalismo?, p. 214.

17 Prado, Un juez rural. p. 168. 


\section{Palabras al cierre (la ideología)}

Hay temas interesantes que la novela me sugiere y que no he podido tratar aquí. Quiero destacar tres de ellos: la tensión entre el estado emocional de Solaguren y las virtudes doxásticas, es decir, la relación entre la soledad y la pesadumbre con un determinado estado de creencia ingenua, escepticismo o dogmatismo; segundo, como la prudencia media (o no) entre la emocionalidad y las virtudes doxásticas; tercero, la relación simbólica y alegórica entre las actividades que desarrolla el protagonista; la arquitectura, la pintura y la justicia, por un lado, y la creación, representación, presentación del mundo y de la comunidad, por otro.

Parece necesario destacar cómo la lectura éticamente atenta de novela en estudio permite al lector cultivar lo que Martha Nussbaum ha Ilamado 'imaginación literaria', esto es, "una imaginación pública, una imaginación que sirva para guiar a los jueces en sus juicios, a los políticos cuando midan la calidad de vida de gentes cercanas y lejanas ${ }^{\prime 18}$. En palabras de Nussbaum, la lectura de novelas a través de argumentos, teoría moral y política permite desarrollar esta imaginación que evita que la imparcialidad sea obtusa y la justicia ciega, ya que 'fantasear', más allá de sus aptitudes técnicas, ayuda a comprender el conflicto y a sus participantes ${ }^{19}$. Por otro lado, en contra de esta idea general, Jorge Malem ha postulado que el juez "ha de huir de las adjetivaciones excesivas y del uso de metáforas. Y no debe referir a mundos imaginarios o a cuestiones para las que carece de estricta competencia jurídica. Decididamente, el juez no se puede comportar como un literato, aunque comparta con él la necesidad de conocimiento de la lengua que utiliza en su trabajo"20.

A mi juicio, ambas posiciones se muestran como ideologías sobre la administración de justicia, porque toda evaluación moral es expresión de nuestras creencias y, habitualmente, ellas están al servicio de algún poder inconfeso. Así, la diferencia entre Nussbaum y Malem es solo aparente. Una enfatiza la noción de razonamiento práctico, individualista de inspiración kantiana y la otra prefiere a la intuición moral como medio de resolución de problemas morales y jurídicos. La apariencia radica en que ambas, a fin de cuentas, conducen a la valoración de las conductas de los jueces. Esto es así, porque tanto para Nussbaum como para Malem la creencia en virtudes judiciales no es solo un estado mental 'íntimo' del juez, sino que esa creencia se "materializa en la actividad social efectiva: la creencia sostiene la fantasía que regula la realidad social'21. En otras palabras, los jueces no son 'buenos jueces' porque crean

\footnotetext{
18 Nussbaum, Martha. Justicia Poética (Madrid: Editorial Andrés Bello, 1997), p. 27.

19 Ibíd., p. 163.

20 Jorge Malem, El error judicial y la formación de los jueces (Barcelona: Gedisa, 2008), p. 238.

21 Slavoj Žižek, “¿Cómo Marx creó el síntoma?”, en Ideología, Un mapa de la cuestión (Argentina: Fondo de Cultura Económica, 2008), p. 353.
} 
en la justicia o cultiven alguna virtud judicial, sino que la creencia se justifica en una previa conducta judicial correcta, que es previa al estado de creencia. De este modo, solo encontramos razones que justifican o confirman nuestras creencias en un determinado conjunto de virtudes judiciales únicamente una vez que ya creemos en ellas; no es que creamos porque hayamos descubierto buenas o novedosas razones para creer. Esta forma de ver el problema nos da una nueva clave de lectura de la novela. Solaguren decide ser juez (y decide renunciar) porque ya cree en un cierto conjunto de virtudes y no al revés.

\section{Bibliografía}

Arriagada, Julio y Hugo Goldsack. "Pedro Prado, un clásico de América" Revista Atenea de la Universidad de Concepción (Chile) 321, 322, 323, 324 (1952).

De la Torre Díaz, Francisco Javier. Alisdair Maclntyre iun crítico del liberalismo? Madrid: Dykinson, 2005.

Genette, Gerald. "El discurso del relato", en Figuras III. Barcelona: Lumen, 1986.

Maclntrre, Alasdair. Tras la virtud. Barcelona: Crítica, 1987.

. Whose justice? Which rationality? Indiana: University of Notre Dame Press, 2003.

MAlem, Jorge. El error judicial y la formación de los jueces. Barcelona: Gedisa, 2008.

Ost, Françols. "El reflejo del Derecho en la literatura". Revista Doxa de Teoría y Filosofía del Derecho 29 (2006).

Prado, Pedro. Un juez rural. Santiago: Editorial Universitaria, 1996.

ŽižEK, SlAVOJ. “¿Cómo Marx creó el síntoma?”, en Ideología, Un mapa de la cuestión. Argentina: Fondo de Cultura Económica, 2008. 



\title{
VERDAD Y JUSTICIA EN AMÉRICA LATINA EN CASOS DE VIOLACIONES A LOS DD.HH.
}

\author{
TRUTH AND JUSTICE IN LATIN AMERICA IN CASES OF VIOLATIONS TO THE \\ HUMAN RIGHTS
}

Héctor Salazar Ardiles

Fecha de recepción: 6 mayo de 2010.

Fecha de aceptación: 17 de mayo de 2010

\begin{abstract}
Resumen
El presente artículo da cuenta de los procesos de transición de diversas dictaduras militares de Hispanoamérica a regímenes democráticos, ocurridos en las últimas tres décadas del siglo pasado, poniendo el foco de atención en la manera como en distintos países de la región se enfrentó la pesada carga en materia de violaciones a los derechos humanos heredadas de esas dictaduras, así como los diferentes grados de verdad y justicia alcanzados en cada uno de esos procesos, como las dificultades que surgieron para alcanzar dicho cometido. Especial consideración se hace con respecto al caso chileno y los resultados obtenidos en esta área.
\end{abstract}

Palabras clave: impunidad, transiciones, verdad y justicia, deuda, dictaduras, democracia.

\begin{abstract}
The present article gives account of the processes of transition of diverse military dictatorships of Hispanic America to democratic rate happened in the last three decades of last century, putting the area of attention in the way since in different countries of the region the heavy load faced as for violations the human rights inherited from these dictatorships, and the different degrees indeed and justice reached in each of these processes as the difficulties that arose to reach the above mentioned assignment. special consideration is done with regard to the chilean case and the results obtained in this area.
\end{abstract}

Key words: impunity, transitions, truth and justice, debt, dictatorships, democracy.

* Abogado. Licenciado en Ciencias Jurídicas y Sociales, Universidad Central de Barcelona, España. Profesor de Derecho Político en la Universidad Academia de Humanismo Cristiano y Universidad Católica de Temuco. Profesor invitado de la Maestría en Derechos Humanos de la Universidad Rafael Landivar de Guatemala. Profesor invitado del diplomado de Especialización en Derechos Humanos y Comunicación, impartido por la fundación Henry Dunant América Latina. 
Nuestro continente desde 1970 y hasta fines del 90 ha sufrido violentos conflictos sociales y políticos que dejaron tras de sí una pesada herencia en materia de violaciones a los derechos humanos.

Cuando esos conflictos comenzaron a ser superados y nuestras comunidades nacionales buscaron recobrar su normalidad democrática, quizás uno de los problemas más serios que debieron enfrentar decían relación en cómo enfrentar esa herencia de un modo que los caminos decididos permitieran dar un cauce civilizado y éticamente aceptable a fin de superar dichos traumas.

Se trataba de compatibilizar un proceso efectivo y sostenible de normalización democrática con las crecientes necesidades de establecer la verdad y realizar la justicia de cientos de miles de graves crímenes.

Esta inmensa tarea -por cierto- que no resultaba fácil si se tiene presente que nuestras sociedades fueron profundamente afectadas por una violencia política "generalizada" caracterizada por muertes, desapariciones forzadas, torturas, dictaduras militares y guerras internas.

Lo anterior ha llevado a plantearnos cómo reconciliar sociedades profundamente fracturadas, establecer la verdad de todo lo ocurrido y hacer la justicia necesaria con relación a tanto crimen.

Sin duda, hoy hay conciencia general de que esa reconciliación (o reencuentro como señalan otros) no es posible si no hay verdad, ni verdad sin justicia.

Hace treinta años solo tres países de Latinoamérica tenían sistemas democráticos de gobierno. En la actualidad, la situación es inversa, contando nuestros países con sistemas institucionales que garantizan, al menos en el papel, los derechos fundamentales.

En algunos de nuestros países, como forma de reencontrarse con su proceso de democratización, se establecieron comisiones de la verdad y de esclarecimiento histórico, entendidas como instrumentos idóneos para investigar los atroces acontecimientos del pasado reciente y garantizar la justicia.

En algunos casos, dichas instancias fueron creadas como instituciones oficiales, por ejemplo en Chile (Comisión Rettig), Argentina y Perú, o fueron fruto de iniciativas de la sociedad civil y, particularmente, de las ONG de DD.HH.; o resultaron como consecuencia de acuerdos de paz como ocurrió en El Salvador y Guatemala.

Dichas experiencias han generado un debate ya de varios lustros que busca comprender los aspectos más relevantes de estos procesos de reconstrucción democrática. 
Sin embargo, algunas conclusiones ya ha sido posible establecer:

- Se trata de procesos muy complejos y de largo plazo.

- No son procesos importables; no existen modelos o recetas válidos en cualquier tiempo y lugar.

- En ellos juega un papel esencial el establecimiento de la verdad y la realización de la justicia, $y$

- Finalmente, es necesario ir construyendo en ellos una cultura de respeto y promoción de los DD.HH.

La reconstrucción democrática de nuestras sociedades ha estado marcada por una perspectiva de búsqueda de la verdad y la justicia en materia de violaciones a los derechos humanos cometidas dentro de ellas, entendidas, estas, fundamentalmente, como afectación a los derechos civiles y políticos.

En el mundo de los DD.HH. se sostiene, con mucha vehemencia, que no habrá posibilidades de paz y reconciliación en nuestras sociedades si no se hace justicia y se castigue a los culpables de estos crímenes, lo que importa es una afirmación de la justicia retributiva como prioridad inmediata, sin dejar de afirmar también la necesidad de la justicia compensatoria o reparatoria. Con ello, se argumenta, se reducen los riesgos de la autotutela, se inhiben iniciativas de repetir esas experiencias traumáticas, se dignifica a las víctimas, se individualizan las culpas y se fortalece la legitimidad del proceso democratizador.

Así, la justicia se constituye además en un ritual ético y de renacimiento político que afianza el valor de la democracia y se erige en un formidable muro contra la impunidad.

Es precisamente la necesidad de romper el círculo de la impunidad uno de los desafíos más cruciales de este proceso, en nuestra América es uno de los problemas más complejos que se han debido enfrentar.

Si bien es cierto que los tribunales pasan a ser los instrumentos "por antonomasia" necesarios para establecer la verdad y hacer justicia, nuestra realidad nos enseña que nuestros sistemas judiciales no tienen la capacidad o no se encuentran preparados para juzgar crímenes a gran escala. Tampoco, dado su diseño hecho para establecer las responsabilidades individuales, nos entregan una visión global que permita establecer patrones de conductas colectivas que permitieron la violencia y el terror en términos tan masivos. De allí que haya sido necesario, como complemento, dentro del campo de la justicia retributiva, el establecimiento de órganos jurisdiccionales de carácter internacional.

La experiencia indica que la jurisdicción universal y la instalación de tribunales internacionales, con todas las limitaciones que presentan, hacen un significativo aporte en esta materia, incluso, se transforman en una alternativa viable a los tribuna- 
les nacionales, más aún cuando estos se muestran incapaces de acometer esta gravitante tarea.

Existen experiencias interesantes como la del Tribunal de Estraburgo y la Corte Interamericana de Derechos Humanos, que son instancias internacionales de apelación por violaciones a los derechos humanos cuando se agotan los recursos internos del país.

Los mecanismos de la justicia internacional son útiles cuando no se logra la justicia en el propio país; son la respuesta al desarrollo de niveles más altos de conciencia universal respecto de la necesidad de respetar los DD.HH. Asimismo, juegan un rol disuasivo relevante respecto de futuras eventuales violaciones. Además, mediante dichas instancias, la comunidad internacional se involucra directamente en procesos que tienen un fuerte impacto en las comunidades nacionales, haciendo más solidaria y amplia la demanda no satisfecha.

\section{La experiencia de nuestra región}

Tras décadas de vivir bajo el influjo de dictaduras militares y conflictos armados internos, nuestra América Latina se orientó en la década de los 90 hacia la reconstrucción democrática y dio pasos a procesos de reconciliación o reencuentro nacional.

El objetivo de la reconciliación nacional, sobre la base de garantizar una cierta estabilidad del proceso democrático y la refundación o democratización de las instituciones, junto con la definición de una política para enfrentar la deuda pendiente en materia de violaciones a los derechos humanos, fueron los desafíos claves de ese período.

En lo que respecta a la justicia, estos procesos de transición debieron enfrentarse a legislaciones heredadas que buscaban impedir las investigaciones en casos de violaciones a los DD.HH., así como a la autolimitación que se impusieron para evitar conflictos con un poder militar aún vigentes.

En diferentes momentos de las dictaduras o conflictos armados, las autoridades de la época dictaron leyes de amnistía para impedir que se investigaran tales violaciones. Estas leyes fueron un serio obstáculo de las transiciones en la lucha contra la impunidad. Así, por ejemplo, en Chile se dictó el Decreto Ley 2.191. El año 1978, que importó un blanqueo feroz de todos los crímenes de la dictadura. Con todo, no fue el único obstáculo que enfrentaron las acciones judiciales de las víctimas, también se utilizó la institución de la prescripción a fin de eludir investigar casos de torturas, ejecuciones extrajudiciales y desapariciones, y se ejercieron presiones directas desde las FF.AA. sobre las autoridades civiles para frenar el avance de los procesos. Sin embargo, las necesidades de brindar una justicia material fueron presionando a los jueces 
que, superando sus iniciales temores, se abrieron a la tarea de investigar. Un fuerte impulso en este sentido lo brindó la Mesa de Diálogo el año 2000, cuando las FF.AA. terminaron reconociendo que durante la dictadura militar se habían violado los DD.HH. Fue así que se estableció un mecanismo judicial con jueces con dedicación exclusiva a investigar estas causas, y los uniformados se comprometieron a colaborar con la justicia. Antes, las investigaciones judiciales no habían logrado significativos avances, no obstante contar con antecedentes que permitían hacerlo.

En El Salvador, cinco días después de publicación del informe de la Comisión de la Verdad, la mayoría derechista del partido ARENA aprobó en el congreso una amplia amnistía tanto respecto de la responsabilidad penal como civil de los violadores a los DD.HH. Así las víctimas se vieron privadas de accionar a fin de hacer efectiva dichas responsabilidades y reclamar reparaciones respecto de hechos anteriores al año 1992. La Corte Suprema salvadoreña se negó a revisar esa ley.

Por su parte, en Guatemala, con la suscripción de los acuerdos de Paz, la guerriIla y el gobierno convinieron en la reintegración de los ex combatientes, lo que se tradujo en la dictación de la Ley de Reconciliación Nacional, conforme a la cual fueron amnistiados todos los que habían cometido delitos en el marco del conflicto armado, excluyendo la desaparición forzada, la tortura y el genocidio. Jurisprudencialmente, la Corte Suprema guatemalteca ha señalado que el análisis de si es aplicable o no esa amnistía debe hacerse cuando los fiscales conocen del caso, mediante consulta a las instancias jurisdiccionales superiores. Lo anterior, ha inhibido las investigaciones judiciales ya que la Corte Suprema de ese país ha anulado investigaciones en que se había logrado demostrar la responsabilidad criminal de militares, argumentando que no se había realizado ese trámite de la consulta.

En Perú, la justicia ha operado de forma muy desigual. Por una parte, se ha mostrado muy estricta y rigurosa en contra de la insurgencia -Sendero Luminoso y MRTA-, sobre todo durante el gobierno de Fujimori, época en que se Ilevaron a cabo miles de detenciones arbitrarias y juicios sumarios sin ninguna garantía procesal, en tanto que los militares implicados en violaciones a los DD.HH. no fueron investigados. El Congreso peruano decretó una amnistía el año 1995, declarando que "todos los hechos originados o derivados como consecuencia de la lucha contra el terrorismo" cometidos por personal militar quedaban amnistiados. Un mes después, a fin de dejar todo bien amarrado, se aprobó una nueva ley que impedía a los jueces revisar si la amnistía era aplicable o no. Con todo, algunos avances se han logrado recientemente con ocasión del juzgamiento al ex presidente Fujimori, cuando algunos capítulos, materia de la acusación, se refirieron a casos de violaciones a los DD.HH. junto con cargos por corrupción, materia sobre la que también pesaron cargos judiciales, en Chile, en contra del general Pinochet.

El caso argentino también sufrió los embates de la impunidad. A fines de 1983, con el retorno de la democracia a la Argentina, los familiares de la víctimas de la 
represión militar iniciaron la búsqueda de la verdad respecto a la suerte de miles de desaparecidos sufriendo amenazas y marcados por el temor que habían logrado instalar los represores. De allí en adelante la política argentina ha estado marcada por avances y retrocesos en el comportamiento del Estado para dar respuesta a los reclamos por violaciones a los DD.HH. El gobierno de Raúl Alfonsín creó la CONADEP (Comisión Nacional sobre Desaparición de Personas), la que, luego de un año de trabajo, evacuó su informe titulado "Nunca Más", que entregó los elementos necesarios para enjuiciar posteriormente a los autores de los crímenes cometidos durante el período dictatorial. Al efecto se dictó una ley (Ley 23.049) que entregó a la jurisdicción militar dicha tarea. Sin embargo, en 1984, el Consejo Supremo de las Fuerzas Armadas resolvió que las órdenes dictadas en el "ejercicio de la lucha contra la subversión" eran "inobjetablemente legítimas", por lo que las investigaciones en dicha sede no avanzaron. En abril de 1985 la Cámara Federal en lo Criminal y Correccional de la Capital Federal tomó a su cargo estos procesos y dio inicio a los juicios a las tres juntas militares que habían gobernado Argentina. El 9 de diciembre dicho tribunal dictó sentencia sosteniendo la existencia de un plan sistemático, deliberado y concertado para la política de la represión encubierta y condenó a cinco de los comandantes por delitos de homicidios, privación ilegítima de libertad y torturas, entre otros, abriendo cauce a nuevos y numerosos procesamientos en los tribunales del país. Tres años después, esto es en 1987, bajo el eufemismo de que el país no podía vivir en un "estado general de sospecha e incertidumbre", y bajo el pretexto que había que "acelerar los juicios", se dieron los primeros pasos en un proceso destinado a establecer la impunidad en materia de violación a los DD.HH., dictándose las leyes de Punto Final y de Obediencia Debida, por el Congreso durante el gobierno de Raúl Alfonsín. Posteriormente, a tres meses de asumido el mando por el presidente Menem, este dispuso indultar a 267 personas que no se habían beneficiado de las dos leyes dictadas durante el gobierno de Alfonsín. Se trató de 39 militares acusados de graves violaciones a los DD.HH., 64 ex guerrilleros o militantes políticos contrarios a la dictadura militar y tres ex comandantes en jefe de las FF.AA., entre otros.

Por su parte, en Uruguay, una ley que impidió toda investigación en materia de violaciones a los DD. HH, ha logrado imponerse hasta el presente y los intentos de derogarla mediante plebiscitos han fracasado, encontrándose una cerrada oposición de parte de los gobiernos posteriores a la dictadura militar por promover una política de verdad y justicia en estos ámbitos, imponiéndose la impunidad prácticamente sin contrapesos, no obstante la decidida lucha que han dado los organismos de derechos humanos de ese país por romper ese bloqueo.

Brasil ha sostenido persistentemente una política de dar vuelta la hoja respecto de las violaciones a los derechos humanos cometidas durante la dictadura que vivió ese país hace más de tres décadas. No se conocen políticas en materia de verdad y justicia que se hayan promovido desde los gobiernos democráticos postgobierno autoritario. Así las cosas, el cuadro que presenta nuestra región no es muy alentador en estas materias. 
Al parecer, las necesidades políticas de asentar débiles procesos de reconstrucción democrática, se hizo sobre bases muy precarias y bajo la presencia siempre amenazante de los poderes militares cuyo retiro del primer plano de la política y del ejercicio del gobierno de sus respectivos países fue más aparente que real. El poder militar conservó importantes cuotas de poder efectivo que ahora se manifestaba por medio de una suerte de facultad de veto encubierto que se ejerce a través de sus aliados civiles, que históricamente se han encontrado en los sectores más conservadores de la sociedad.

Con todo, a pesar de las dificultades anotadas, las necesidades de verdad y justicia en nuestro continente no han podido ser apagadas. Ha pasado el tiempo y la demanda sigue vigente.

Existe en la conciencia moral de nuestros pueblos de que ello no puede ser soslayado y que tarde o temprano esta deuda pendiente debe ser saldada. Quizás si el caso de nuestro país sea sugerente en este sentido.

Las complejidades de nuestra transición se manifestaron de forma evidente cuando las demandas de verdad y justicia lograban algunos avances. Fue así como la presión militar se hizo sentir en más de alguna ocasión logrando sus objetivos y paralizando a la clase política gobernante muy permeable a dichas presiones.

Así se logró que el tema de la deuda pendiente en materia de violaciones a los DD.HH. fuera desapareciendo de la agenda nacional. Sin embargo, los familiares de las víctimas, asistidas por organismos de DD.HH., no cesaron de requerir de los tribunales de justicia una respuesta. Por cierto que la respuestas era exiguas y los avances muy precarios. Y así pasaban los años.

Las FF.AA. en nuestro país habían apostado a que el transcurso del tiempo iría desgastando estas demanda hasta que dejarían de ser un escollo en el devenir nacional y un problema de pequeños grupos sin mayor significación, así la impunidad se impondría como algo natural: el olvido.

Sin embargo, ocurrió algo no previsto: el año 1999 Pinochet cae detenido en Londres, por acción de la justicia internacional, y el país se ve sacudido por ese hecho. De un día para otro, un tema que había desaparecido del debate aflora potente e intensamente en la agenda nacional, quedando en evidencia que existía un problema pendiente del cual la sociedad no se había hecho cargo: las violaciones a los DD.HH. durante la dictadura militar.

La irrupción del tema y la movilización de la población detrás de él con la consecuente demanda de verdad y justicia llevó a que las FF.AA. de nuestro país, junto con las autoridades de gobierno, emprendieran una iniciativa que se denominó La Mesa de Diálogo de Derechos Humanos, donde, bajo los auspicios del ministro de 
Defensa, se reunieran representantes de los comandantes en jefe de todas las ramas de la defensa nacional con personeros provenientes del movimiento de los DD.HH. y autoridades morales representativas de los sectores más relevantes del país.

Fruto de dicha Mesa de Diálogo, las FF.AA. aceptaron, por primera vez, reconocer que efectivamente durante el gobierno militar se habían violado los DD.HH. y que ello había sido una política sistemática. Se comprometieron a un "nunca más" y a respetar la institucionalidad democrática, reconociendo que la única instancia válida para acometer este problema eran los tribunales de justicia, a los cuales comprometieron toda su colaboración.

Además, se propuso un sistema de jueces con dedicación exclusiva en la tramitación de estas causas, brindándoseles los apoyos logísticos necesarios para llevar a cabo su tarea.

Por cierto que la colaboración ofrecida por las FF.AA. fue más nominal que real, pero la verdad es que la investigaciones judiciales adquirieron un dinamismo impresionante a partir del año 2000, que se traduce en la siguiente estadística de resultados:

\section{Causas por violaciones a los DD.HH. al 31.7.2010}

1) Total de juicios: $\mathbf{4 2 3}$

2) Estos 423 juicios involucran a $\mathbf{1 . 1 7 1}$ víctimas.

3) Entre el 31.7.2005 al 31.7.2010 han concluido 82 juicios con condenas.

4) Los 82 juicios concluidos con condena involucran a189 víctimas.

5) Desde que hay actividad jurisdiccional por denuncia de violaciones a los DD.HH., se han dictado $\mathbf{3 . 0 5 2}$ resoluciones de procesamiento o acusaciones que han afectado a 558 agentes del estado (234 de ellos figuran en más de una resolución).

6) Hasta la fecha se han dictado $\mathbf{5 0 6}$ sentencias condenatorias que afectan a 290 agentes del estado, 83 de los cuales tienen más de una condena.

7) Igualmente, hasta la fecha se han dictado 46 sentencias absolutorias a favor de agentes del estado, todas las que se encuentran en fase de apelación.

8) Tipos de agentes del Estado procesados o condenados:

a) 354 miembros del Ejército, 118 ya condenados:

- 32 generales

- 24 brigadieres

- $\quad 55$ coroneles 
- 20 tenientes coroneles

- $\mathbf{2 5}$ mayores

- 8 capitanes

- 130 suboficiales

- 39 empleados civiles

- 21 inclasificables

b) $\mathbf{6 0}$ miembros de la Marina, $\mathbf{1 6}$ ya condenados:

- 6 vice o contraalmirantes

- 7 capitanes de navío

- 6 capitanes de fragata

- 30 suboficiales

- $\quad 2$ empleados civiles

- 9 inclasificables

c) 52 miembros de la Fuerza Aérea, 19 ya condenados:

- 3 generales

- 9 coroneles

- 3 tenientes coroneles

- 1 mayor

- 3 capitanes

- 20 suboficiales

- 12 empleados civiles

- 1 inclasificable

- 248 miembros de Carabineros de Chile, 121 ya condenados:

- 6 generales

- $\mathbf{1 7}$ coroneles

- $\mathbf{1 0}$ tenientes coroneles

12 mayores

- 10 capitanes

- 178 suboficiales

- 1 empleado civil

- 14 inclasificables

e) 20 miembros de la Policía de Investigaciones, 9 ya condenados.

f) 1 miembro de Gendarmería de Chile, ya condenado.

g) 53 civiles, 6 ya condenados.

9) En total, hasta el presente, $\mathbf{7 8 8}$ agentes del Estado han sido requeridos por nuestros tribunales de justicia por su presunta participación en violaciones a los derechos humanos, de los cuales $\mathbf{2 9 0}$ se encuentran condenados.

En suma, la experiencia indica que la verdad y la justicia son posibles en un porcentaje significativo; que se trata de una demanda que está instalada en la conciencia moral de nuestros pueblos y que más temprano que tarde se abrirán también las anchas alamedas para que esa verdad y esa justicia, aún pendientes, se hagan realidad. 



\title{
APUNTES SOBRE LAS DIFICULTADES EN LA DETERMINACIÓN DEL ESTATUS CIENTÍFICO DE LA CRIMINOLOGÍA
}

\author{
NOTES ON THE DIFFICULTIES IN DETERMINING THE SCIENTIFIC STATUS OF \\ CRIMINOLOGY
}

Sebastián Alonso Agüero San Juan*

Fecha de recepción: 13 de mayo de 2010.

Fecha de aceptación: 10 de junio 2010.

\section{Resumen}

El presente artículo configura una panorámica de los problemas que tiene enjuiciar a la criminología como ciencia. Se revisan los principales criterios usados normalmente para asignar el rótulo de 'ciencia' a una determinada disciplina y se concluye con una propuesta de ordenación de tales criterios.

Palabras clave: criminología, pseudociencia, disciplinas científicas.

\begin{abstract}
This article sets an overview of the problems with prosecuting criminology as a science. We review the criteria normally used to assign the label of 'science' to a particular discipline and concludes with a proposal for management of these criteria.
\end{abstract}

Key words: criminology, pseudoscience, scientific disciplines. 
"...Algo así como un parásito, la criminología se une a sus materias anfitrionas (en particular, derecho, psicología, psiquiatría y sociología) y de ellas extrae métodos, teorías y credibilidad...".

Stanley Cohen 1988.

"El crimen a veces se caracteriza como una ciencia social de atracción turística, un Taj Mahal o Torre de Pisa, que visita todo el mundo una sola vez. Por lo tanto los teóricos más importantes, como Durkheim, Parsons o Merton han hecho apariciones claves, pero breves en la escena del crimen".

Frances Heidnsohn 1989.

\section{Introducción}

El estudio de manuales dedicado a una disciplina en particular entrega una visión, no solo de conocimientos básicos sobre la materia que permiten, una vez aprendidos, introducirse con mayor profundidad en el área, sino, también, de cuáles son las principales interrogantes que atormentan a dicho ámbito del conocimiento.

En este último sentido, al revisar libros de textos sobre Criminología es posible constatar, principalmente, en sus primeros capítulos, una excesiva cantidad de argumentos destinados a justificar su carácter o estatus científico ${ }^{1}$, mientras que, también, se observa, la exposición de una relación problemática entre 'Ciencia' y 'Criminología' ${ }^{2}$. Cabe señalar que esto sucede sin perjuicio del tratamiento realizado por algunos autores que, sin introducirse en la discusión, dan por sentado el carácter científico de la Criminología ${ }^{3}$.

Los criminólogos imbuidos en la problemática, por lo general, presentan una serie de argumentos destinados a obtener el reconocimiento científico de la 'Crimino-

En sentido: García-Pablos de Molina, A. Criminología: Una introducción a sus fundamentos teóricos (Quinta edición ed.). Valencia: Tirant lo Blanch, 2005; Garrido, V., Stangeland, P. \& Redondo, S. Principios de Criminología. Valencia: Tirant lo Blanch, 2006; Lanier, M. M. \& Stuart, H. Essential Criminology (Tercera edición ed.). Philadelphia: Westview Press, 2010; Serrano Maíllo, A. Introducción a la Criminología (Quinta edición ed.). Madrid: Dykinson, 2008.

2 Siguiendo esta línea: Coleman, C. \& Norris, C. Introducing Criminology. Portland: Willan Publishing, 2000; Kaiser, G. Introducción a la Criminología (Séptima edición ed.). (N. J. Rodríguez \& J. M. Rodríguez Devesa, Trads.) Madrid: Dykinson, 1988; Newburn, T. Criminology. Portland: Willan Publishing, 2007; \& Tierney, J. Criminology: theory and context (Segunda edición ed.). London: Pearson Education Limited, 2006.

3 Con este enfoque: Cid Moliné, J. \& Larrauri Pijoan, E. Teorías Criminológicas. Barcelona: Bosch, 2001; y Roldán Barbero, H. Introducción a la investigación criminológica. Granada: Editorial COMARES, 2009. 
logía'. En concreto, su estructura argumental puede ser caracterizada por tres elementos: (1) su objeto de estudio lo constituye la realidad empírica, (2) su metodología es la utilizada de manera general en las ciencias sociales, y (3) su producto es un conocimiento válido, fiable y contrastable. Sin embargo, existe otro grupo de autores, más cuidadosos al momento de otorgar carácter científico a la Criminología, para quienes resulta esencial señalar la diversidad de enfoques disciplinarios utilizados en Criminología, pues ello conlleva ciertas indeterminaciones internas que dificultan aún más la obtención del atributo científico.

No obstante, tomando algo de distancia de estas formas de abordar el estatus científico de la Criminología, en el presente trabajo se pretende exponer y desarrollar las principales dificultades que deben sortear los criminólogos al momento de atribuir o designar con la palabra 'ciencia' a su objeto de estudio.

Por consiguiente, la presentación de los inconvenientes se efectuará realizando un tratamiento separado de las nociones: 'Criminología' y 'Ciencia', donde se explicita la indeterminación conceptual de ambas, y luego se destacan algunos elementos considerados como integrantes de su contenido significativo, así, en base a ellos, realizar una contrastación entre ambas nociones que permita proponer un respuesta a la cuestión de si la Criminología posee (o no) estatus científico.

\section{Sobre la Criminología}

La palabra 'Criminología' presenta algunos problemas relativos a su denotación, es decir, a los objetos a los cuales se refiere. Esta indeterminación se manifiesta o es consecuencia de que la disciplina no ha circunscrito definitivamente su objeto de estudio. En concreto, los manuales estudiados difieren en cuanto a lo que debe entenderse por Criminología. Consciente de estas diferencias Tierney sostiene que "...la complejidad de los contornos de esta investigación aparentemente simple, puede destacarse, señalando que no es inusual que criminólogos de avanzada edad aún debatan sobre estas cuestiones ${ }^{4}$. Aun así, es posible agrupar a los autores en atención a los aspectos que consideran como esenciales dentro del estudio criminológico.

Un primer grupo propone que la Criminología tiene por objeto de estudio: el delito o crimen, el delincuente o infractor, la víctima, y el proceso de criminalización o control social ${ }^{5}$. Un segundo grupo centra sus investigaciones en: el crimen, el

Tierney, Criminology: theory and context, op. cit, pág., 11.

5 En este sentido: Cid y Larrauri, Teorías Criminológicas, op. cit.; García-Pablos, Criminología: Una introducción a sus fundamentos teóricos, op. cit.; y Roldán, Introducción a la investigación criminológica, op. cit. 
delincuente y el sistema penal o de control del delito ${ }^{6}$. Un tercer grupo sostiene que el saber criminológico se sustenta en dos pilares: el comportamiento delictivo y la reacción social a dichos comportamiento, para unos ${ }^{7}$, y el delito y el delincuente como fenómenos globales, para otros ${ }^{8}$. Finalmente, un cuarto grupo se centra en el delito o crimen, entendido como un fenómeno omnicomprensivo de casi todas las otras materias recién enunciadas ${ }^{9}$.

La agrupación de autores, por concepciones criminológicas, permite proponer o atribuir un campo de estudio difuminado a la Criminología, el cual de manera centrífuga se desvanecería desde el estudio del crimen o delito (situado en el centro), por convertirse en un lugar común a todas las propuestas, hacia las investigaciones sobre víctimas (ubicadas en la periferia), por ser elementos contingentes, y atravesando al delincuente y el control social (posiciones en la zona media), por obtener un consenso relativo.

Ahora bien, la propuesta anterior no debe pasar por alto otra indeterminación, presente en los planteamientos criminológicos, derivada de los significados atribuidos a los términos utilizados para delimitar su objeto. En este sentido, las afirmaciones de Coleman y Norris sobre 'crimen' y 'criminal' resultan sumamente ilustrativas: “... los criminólogos no están necesariamente de acuerdo sobre la definición de esos dos términos básicos, en lugar de darlos por sentados, algunos criminólogos insisten en que dichos términos deben ser vistos como problemáticos. Cuando los términos crimen y criminal son usados, nosotros debemos ser conscientes de la existencia de usos alternativos de esos términos clave. Los términos crimen y criminal no deben ser aceptados en sentido literal, y la consideración de la definición de ellos es una parte clave del tema de la disciplina..."10. De la misma manera, todos los otros términos utilizados para establecer el campo de los estudios criminológicos (víctima, control social, sistema penal) adolecen de este tipo de indeterminación, por tanto, se dificulta aún más la labor de delimitación conceptual.

Una vez enunciados los objetos de estudio de la disciplina, algunos autores hacen referencia a dos características distintivas de la Criminología, a saber: su carácter empírico y la diversidad de enfoques disciplinarios utilizados. Ambas características se originan en sus primeros años. La primera, habría entregado autonomía y cierto 'estatus científico' a los estudios criminológicos de mediados del siglo XIX, debido,

\footnotetext{
Siguiendo esta línea: Kaiser, Introducción a la Criminología, op. cit.; y Newburn, Criminology, op. cit.

Contestes con esta propuesta: Garrido, Stangeland y Redondo, Principios de Criminología, op. cit.

$8 \quad$ Este planteamiento es formulado por: Coleman \& Norris, Introducing Criminology, op. cit.; y op. cit.

9 Este camino es recorrido por: Lanier \& Stuart, Essential Criminology, op. cit. \& Tierney, Criminology: Theory and context, op. cit.

10 Coleman \& Norris, Introducing Criminology, op. cit., pág. 13.
} 
principalmente, a la generalización y valoración realizada por el positivismo filosófico del método empírico, el cual vino a desplazar al racionalismo abstracto, formal y deductivo del mundo clásico ${ }^{11}$. Por su parte, la segunda comienza a configurarse con el descubrimiento realizado por la escuela positivista-biológica de la 'persona delincuente', pues dicho hallazgo facilitó sustantivamente la introducción de diversos profesionales a este emergente campo de estudio ${ }^{12}$.

El carácter experiencial comprende la utilización de métodos empíricos (principalmente observación y experimentación), aplicables a los objetos de estudio, para así generar conocimientos fiables y seguros, siempre que dichos conocimientos (teorías o hipótesis) puedan ser verificados o falseados ${ }^{13}$. Este rasgo vincula directamente a la Criminología con las ciencias empíricas, en el sentido de obtener su objeto de estudio del mundo real, verificable y mensurable, en otras palabras, se apropia de una parte de la realidad susceptible de explicación ${ }^{14}$. En este mismo orden de ideas se inserta el tratamiento realizado, por algunos de los textos estudiados, de los planteamientos relativos a los diversos métodos y técnicas de investigación, utilizados por la Criminología, para estudiar la realidad social. Las cuales son agrupadas en dos grandes bloques: (1) cuantitativos, destinados a explicar las causas, génesis o desarrollo de un fenómeno (estudios estadísticos -policiales, judiciales y penitenciaras-, encuestas de victimización, estudios de autodenuncia, entre otros); y (2) cualitativos, encaminados a comprender las profundas claves de un fenómenos (entrevista en profundidad, los grupos de discusión, la observación participante, etc.) ${ }^{15}$.

La diversidad de enfoques disciplinarios utilizados en el saber criminológico, proporcionan una visión de la Criminología como confluencia de diversas formas de construir conocimiento o afluentes. Los principales saberes confluyentes son: la antropología, biología, economía, geografía, historia, filosofía, derecho, ciencias políticas, psiquiatría, psicología y sociología ${ }^{16}$. El hecho de confluir diversas formas de reconstruir la realidad produce, fundamentalmente, dos complicaciones: el cómo abordar esta variedad disciplinar y el cómo mitigar las contiendas disciplinares.

La primera complicación se manifiesta en el enfrentamiento entre la opción multidisciplinaria frente a la interdisciplinar. Lo multidisciplinar hace referencia a un tipo

11 Cid y Larrauri, Teorías Criminológicas, op. cit., pág. 12; y García-Pablos, Criminología: Una introducción a sus fundamentos teóricos, op. cit.; pág. 38.

12 Op. cit., pág. 42.

13 García-Pablos, Criminología: Una introducción a sus fundamentos teóricos, op. cit.; pág. 39.

14 Op. cit., pág. 40.

15 Cid y Larrauri, Teorías Criminológicas, op. cit., págs. 20-21; y García-Pablos, Criminología: Una introducción a sus fundamentos teóricos, op. cit.; págs. 44-48.

16 Coleman \& Norris, Introducing Criminology, op. cit., pág. 15. 
de investigación que abarca o afecta a varias disciplinas, posibilitando que cada una de estas contribuya con sus propios supuestos sobre la naturaleza humana y social, es decir, los objetos de estudio pueden ser visualizados desde diferentes perspectivas $^{17}$. Por otro lado, lo interdisciplinario sugiere una actividad que se realiza con la cooperación de varias disciplinas, es decir, integrando los conocimientos en un todo distinto ${ }^{18}$, para así concentrar las cuestiones relevantes de las otras disciplinas en los problemas criminológicos y condicionar a los investigadores a mantenerse lo suficientemente abierto para contemplar otras especialidades. Frente a ambas propuestas la doctrina toma caminos diversos. Por un lado, se sostiene que la Criminología no sería interdisciplinaria, ya que pocos autores han intentado dicha integración, siendo más apropiado el calificativo de multidisciplinar ${ }^{19}$, y por otro, se reconoce la necesidad de una investigación multidisciplinar, pero se considerada como alternativa real la interdisciplinariedad, ya que pese a exigir del investigador una mayor integración de conocimientos, debiera ser considerada como el destino de la Criminología empírica ${ }^{20}$.

La segunda complicación, derivada de diversos afluentes epistémicos, produce una serie de conflictos y rivalidades internas, porque una de ellas obtenga el predominio sobre otras. Coleman y Norris sugieren que "... cada una de estas disciplinas tiende a: (1) tener sus propios supuestos, ideas y conceptos básicos, (2) un banco de conocimientos compartidos, (3) un enfoque particular de la investigación, (4) favorece métodos de investigación, y (5) una visión del mundo que lleva a tipos particulares de implicaciones políticas" ${ }^{21}$. Si las afirmaciones de los autores ingleses son correctas, resulta evidente la generación de conflictos entre las disciplinas, que pueden ser formulados, siguiendo a Tierney, como competencia sobre: el foco de los estudios, la agenda a seguir, las teorías a emplear, los métodos de investigación y la orientación política $^{22}$.

En definitiva el estado actual de la Criminología impide presentar de manera clara y precisa: cuál es su objeto (u objetos) de estudio, cuál es el contenido atribuido a dicho objeto (u objetos), cuál es la manera de abordar la confluencia de otras disciplinas y cuál es la forma de atenuar las rivalidades entre ellas. Por tanto, con estas indeterminaciones no solo deben lidiar los criminólogos, para quienes proporcionar contornos conceptuales más nítidos puede constituir un deber, sino, también, para

\footnotetext{
17 Lanier \& Stuart, Essential Criminology, op. cit., pág. 18; \& Newburn, Criminology, op. cit., pág. 5.

18 Garrido, Stangeland y Redondo, Principios de Criminología, op. cit., pág. 47; y Kaiser, Introducción a la Criminología, op. cit., pág. 32.

19 Lanier \& Stuart, Essential Criminology, op. cit., pág. 18.

20 Kaiser, Introducción a la Criminología, op. cit., pág. 32.

21 Coleman \& Norris, Introducing Criminology, op. cit., pág. 15. La numeración no se encuentra en el texto original.

22 Tierney, Criminology: Theory and context, op. cit., págs. 11-12.
} 
quienes desean constatar la existencia de un estatus científico por parte de la Criminología.

\section{Ciencia}

La palabra Ciencia presenta serias dificultades en el proceso de delimitar su alcance. Así, en el uso común presenta problemas de ambigüedad (proceso-producto) y vaguedad (denotación notoriamente imprecisa) que repercuten directamente en el ámbito académico, donde la actividad de entregar condiciones suficientes y necesarias plausible para la ciencia, constituye una tarea sumamente ardua, al punto de que muchos filósofos de la ciencia hayan decidido abandonar el problema de la demarcación, es decir, el problema de proponer tales condiciones ${ }^{23}$.

A causa de ello, se intentan abordar dichas dificultades proponiendo asumir 'Ciencia' como un concepto racimo (cluster concept), el cual permite la existencia de variadas actividades relacionadas entre sí por semejanza o analogía y que, pese a actuar bajo su nombre, ninguna por sí sola es la 'ciencia' como tal24. Esta propuesta solo le proporciona una forma o estructura al concepto resultando necesario proporcionarle un contenido. Para satisfacer esta exigencia, se comienza contrastando 'Ciencia' con otro tipo de conocimientos (sentido común y seudociencia), para así obtener ciertos contornos científicos que permiten diferenciarla de otras clases de información. Luego, en atención a ciertos rasgos del saber criminológico, en un primer momento, se expone las características esenciales y principales de las ciencias empíricas, para finalmente, presentar dos marcos generales de referencia (empirista y humanista), que han orientado históricamente la investigación social desde su nacimiento.

Todo este procedimiento, destinado a llenar de contenido el concepto 'Ciencia', proporciona un panorama general de las dificultades a las cuales se deben ver enfrentados los filósofos de la ciencia al momento de determinar, establecer o proponer las condiciones suficientes y necesarias plausibles para la 'Ciencia'.

1) Ciencia y sentido común: Ernest Nagel, en su libro La estructura de la ciencia (1989), sostiene la existencia de un núcleo o significado seguro de la palabra Ciencia, percibido al destacar las diferencias importantes y reconocibles existentes en el uso de la palabra. Estas son resaltadas al comparar sentido común y Ciencia (como tipos de información sobre las cosas), señalando como elementos del significado seguro: a) pretender hallar explicaciones a los hechos, estableciendo cierta relación de depen-

\footnotetext{
23 Plantinga, A. (20 de febrero de 2007), Religion and Science. Recuperado el 1 de abril de 2010, de Stanford Encyclopedia of Philosophy: http://plato.stanford.edu/entries/religion-science/

24 Op. cit.
} 
dencia entre proposiciones aparentemente desvinculadas y poniendo de manifiesto sistemáticamente las conexiones existentes entre temas de información variados; b) estar movilizada por juicios antagónicos, en la medida que al introducir explicaciones sistemáticas de los hechos, discernir entre condiciones y consecuencias de los sucesos, y manifestar las relaciones lógicas entre las proposiciones, (la ciencia) puede atacar las bases de dichos juicios e incluso unificar propuestas; c) intentar disminuir las indeterminación del lenguaje corriente, sometiéndolo a modificaciones, para que sus enunciados sean susceptible de pruebas o críticas, e incorporarlos en sistemas explicativos lógicamente integrados; d) intentar no considerar la valoración humana y los valores inmediatos de las cosas en la determinación de las relaciones de dependencia entre las cosas; e) proponer conceptos abstractos para lograr una explicación general de cosas cualitativamente diversas, expresando las propiedades estructurales del concepto sin hacer referencia a sus cualidades y relaciones individuales, pudiendo así elaborar sistemas explicativos para grandes conjuntos de fenómenos diversos; y f) exponer sus afirmaciones cognoscitivas, repetidamente, a desafíos en condiciones cuidadosamente controladas para obtener datos observacionales críticamente probatorios. Por último, el autor reconoce que las características recién enunciadas se justifican en la medida que adhieren a una política definida de cómo obtener y evaluar elementos de juicio, agregando, que el registro histórico y los logros obtenidos han garantizado la superioridad de esta política ${ }^{25}$.

2) Ciencia y seudociencia: Sven Ove Hansson, en su artículo sobre Sciencie and Pseudo-Science, enuncia y cuestiona los criterios de demarcación científica desarrollados, considerándolos como parte integrante de la tarea de determinar ¿qué creencias son epistémicamente justificadas? Por tanto, postula que es posible encontrar criterios de demarcación en: (1) los positivistas lógicos, quienes sugieren que una declaración científica se distingue de una metafísica por ser, al menos, susceptible de verificación ${ }^{26}$; (2) el falsacionismo, la falsabilidad (criterio sugerido por Karl Popper) es condición necesaria y suficiente, pues una oración (o teoría) es empírico-científica si y solo si es falseable ${ }^{27}$; (3) la resolución de puzles, el criterio de demarcación propuesto por Thomas Kuhn consiste en la capacidad de la 'Ciencia' para resolver puzles o enigmas realizados durante el desarrollo científico normal; (4) el criterio basado en el progreso científico, en esta categoría destaca George Reisch, quién exige a las disciplinas científicas que se integren adecuadamente en o con otras ciencias, pues varias disciplinas científicas poseen fuertes interconexiones basadas en metodolo-

25 Nagel, E. (1989), "La ciencia y el sentido común". En E. Nagel, La estructura de la ciencia (N. Miguez, Trad., págs. 15-26). Barcelona: Paidós.

26 Este criterio es vinculado con la idea que el sentido de una proposición es su método de verificación. Verificación entendida como el proceso de añadir hechos observacionales para corroborar hipótesis, pudiendo quedar estas consolidadas.

27 Una sentencia (teórica) es falesable si y solo si es lógicamente contradictoria con otra sentencia (empírica) que describe un evento lógicamente posible, que puede ser lógicamente posible observar. 
gía, teorías, etc.; y (5) las normas epistémicas, de Robert K. Merton, señalan que la ciencia tiene un ethos, expresable en cuatro imperativos institucionales: universalismo (exigencia de comprobación), comunismo (conocimiento público), desinterés (neutralidad motivacional), y el deber de plasmar los otros imperativos; para concluir señalando que en la comunidad académica habría acuerdos generalizados solo sobre cuestiones puntuales, existiendo aún desacuerdo sobre las generalizaciones ${ }^{28}$.

3) Ciencia material o empírica: Mario Bunge, intentando caracterizar el conocimiento y la investigación científica material o empírica, propone como rasgos esenciales del conocimiento obtenido por esta la racionalidad y objetividad. De manera que el conocimiento es racional si (1) está constituido por conceptos, juicios y raciocinios, es decir, ideas capaces de visualizar modelos y hacer operaciones; (2) esas ideas pueden cambiarse por un conjunto de reglas lógicas, para producir nuevas ideas (inferencia deductiva); y (3) pueden organizarse en sistemas, esto es, en conjuntos ordenados de proposiciones (teorías). Por su parte, el conocimiento de la realidad es objetivo si (1) concuerda aproximadamente con su objeto, es decir, busca alcanzar la verdad fáctica; y (2) verifica la adaptación de las ideas a los hechos, a través de una particular interacción con estos últimos (observación y experimento), que es controlable y hasta cierto punto reproducible ${ }^{29}$.

Luego, Bunge propone catorce características principales de la ciencia material, derivadas de los rasgos esenciales, las cuales pueden agruparse en tres grupo: (1) las relativas al conocimiento científico, el cual es: fáctico, al intentar describir los hechos tal como son con independencia de su valor; trasciende los hechos, en la medida que los descarta, produce y explica; claro y preciso en la forma en la cual se expresa; comunicable, esto es, expresable y público; verificable, pues la comprobación de sus hipótesis involucra la experiencia; sistemático, al ser un sistema de ideas conectadas lógicamente entre sí; general, al ubicar hechos singulares en pautas generales y enunciados particulares en esquemas amplios; legal, ya que inserta hechos singulares en pautas generales Ilamadas leyes; y predictivo, al transcender el presente intentado reconstruir el pasado e imaginar el presente. (2) Las relativas a la ciencia, que se caracterizaría por ser: analítica, al intentar descubrir los elementos que componen cada totalidad, y las interconexiones que explican su integración; explicativa, pues explica los hechos en términos de leyes, y las leyes en términos de principios; abierta, al no reconocer barreras que limiten a priori el conocimiento; y útil, como herramienta para domar la naturaleza y remodelar la sociedad. (3) Y las relativas a la investigación científica, que la presentan como: especializada, debido al enfoque analítico con el cual se abordan los problemas; y metódica, ya que las investigaciones se fundan so-

28 Ove Hansson, S. (3 de septiembre de 2008), Sciencie and Pseudo-Science. Recuperado el 20 de marzo de 2010, de Stanford Encyclopedia of Philosophy: http://plato.stanford.edu/entries/pseudo-science/

29 Bunge, M. (1985), “¿Qué es la ciencia?”. En M. Bunge, La ciencia su método y filosofía (págs. 8-36). Buenos Aires: Ediciones Siglo Veinte. 
bre el conocimiento anterior y proceden conforme reglas y técnicas que han resultado eficaces en el pasado pero que son perfeccionadas continuamente ${ }^{30}$.

4) Ciencia social: Piergiogio Corbetta, en su libro Metodologŕa y técnicas de investigación social, caracteriza las ciencias sociales como condicionadas por dos grandes marcos de referencia: el positivismo y el humanismo, que establecieron los paradigmas ${ }^{31}$ fundacionales de la investigación social, proporcionando procedimientos operativos en causadores del desarrollo de las disciplinas empírico-sociales. El autor dilucida dichos marcos y su constatación en las ciencia sociales, formulando un esquema comparativo basado en: ¿existe la realidad social? (ontología), ¿es conocible? (epistemología) y ¿cómo puede ser conocida? (metodología), presentando sus respuestas dentro tres categorías: Positivismo, Neo y Postpositivismo, e Interpretacionismo. El estudio de estos marcos permite entender cómo las ciencias sociales, en general, responden a dichas preguntas ${ }^{32}$ : Ontolográ, existe una realidad social externa al sujeto susceptible de ser conocida, de manera: a) objetiva en su esencia real, b) imperfecta por las imperfecciones del conocimiento humano, o c) variada, en tanto múltiples y diversas son las perspectivas que las personas utilizan para interpretar los hechos sociales; Epistemología, es posible conocer la realidad considerando: a) una independencia entre sujeto y objeto (dualismo), la no influencia recíproca (objetividad), y descubrir leyes deterministas (causa-efecto), b) elementos de perturbación introducidos por el investigador y sus efectos, la objetividad como ideal regulativo, la falsabilidad como criterio de validación empírica de las afirmaciones, y leyes generalizadoras, probabilísticas y temporales, c) como objetivo la comprensión del comportamiento del individuo y utilizando abstracciones y generalizaciones (tipos ideales y enunciados de posibilidad); Metodología, para conocer la realidad social se pueden emplear: a) métodos y técnicas de investigación inductivas, con pretensiones matemática y basadas en la experimentación, b) instrumentos con soportes positivos (operacionalización, cuantificación y generalización), pero considerando técnicas cualitativas; c) actitudes de interacción entre sujeto y objeto (consideradas como la base del progreso cognoscitivo), para poder comprender el significado de las acciones, por medio de técnicas de investigación cualitativas y subjetivas ${ }^{33}$.

En resumen, los intentos de determinación del contenido científico, diferenciándolo de otros tipos de conocimientos, y luego, una vez delimitados sus contornos

\footnotetext{
Op. cit.
}

31 Paradigma es entendido como una perspectiva teórica fundada sobre adquisiciones precedentes a la disciplina misma, que actúa dirigiendo la investigación, desde la identificación y elección de los hechos relevantes a estudiar, hasta la formulación de las hipótesis depositarias de la explicación del fenómeno observado, y preparar necesarias técnicas de investigación empíricas.

32 La letra a) corresponde a la posición positivista, la letra b) a la postura neo y postpositivistas; y la letra c) representa los planteamientos de los interpretacionistas.

33 Corbetta, P. (2003), Metodología y técnicas de investigación social (M. Díaz Ugarte y S. Díaz Ugarte, Trads.). Madrid: McGraw-Hill. 
diferenciadores, desarrollando los rasgos fundamentales de un área del conocimiento científico, como es el empírico-social, pone de manifiesto la variedad de incertidumbres existentes en torno a qué clase o tipos de conocimientos pueden subsumirse dentro de la categoría científica.

\section{Ciencia y Criminología}

La cantidad y diversas indeterminaciones existentes tanto en el terreno criminológico como en el científico, constituyen por sí mismas una seria dificultad en la tarea de determinar o establecer el estatus científico de la 'Criminología', la cual no debe ser olvidada ni obviada por quienes emprenden dicha actividad.

Pero sin perjuicio de lo anterior, es posible utilizar los acercamientos y delineamientos del concepto 'Ciencia', considerándolos como filtros útiles en la contrastación de los conocimientos con pretensiones de cientificidad. En este sentido, estos pueden agruparse en etapas, considerando su grado de especificidad, lo cual permitiría establecer si un conocimiento es ciencia (en sentido general), si es empírica (como una clase de ciencia) y si es social (como especie de empírica). De esta forma, es posible contrastar las nociones de 'Criminología" a las nociones de 'Ciencia' para apreciar si las primeras participan o contienen características de las segundas.

En este orden de cosas, los criterios de la primera etapa pueden sintetizarse en las siguientes afirmaciones sobre el conocimiento científico: (1) pretende explicar los hechos, fenómenos o realidades, estableciendo conexiones entre proposiciones, materias o hechos aparentemente desvinculados y presentándolas de manera sistemática; (2) intenta disminuir la imprecisión del lenguaje corriente al establecer sus propuestas; (3) es valorativamente neutro, pretendiendo no considerar valoraciones humanas o de las cosas; (4) propone conceptos abstractos, capaces de explicar de manera general cosas cualitativamente diversas; (5) necesita de la comprobación de sus proposiciones, la cual se puede realizar por verificación o falseación; y (6) puede integrarse en otros sistemas explicativos lógicamente integrados o áreas del conocimiento reconocidas como científicas.

La segunda etapa está compuesta por afirmaciones distintivas de las ciencias empíricas: (1) sus explicaciones de los hechos pretenden concordar con ellos (verdad fáctica); (2) las propuestas son contrastadas con los hechos (observación y experimentación); (3) establece leyes, ya que inserta hechos singulares en pautas generales Ilamadas leyes (hechos-leyes-principios); (4) son predictivas, al transcender el presente intentado reconstruir el pasado e imaginar el futuro; (5) intentan descubrir y explicar los elementos e interconexiones que componen una totalidad (analíticas); (6) persiguen la utilidad, siendo herramienta para domar la naturaleza y remodelar la sociedad; y (7) serían metódicas, al planificar sus pasos a seguir. 
La tercera y última etapa sugiere los rasgos esenciales de una ciencia social: (1) reconoce la existencia de una (o varias) realidad social externa al sujeto; (2) considera posible conocer dicha realidad de manera independiente y objetiva o de modo comprensivo, pudiendo establecer para ello leyes (deterministas o probalístico-temporales) o generalizaciones y abstracciones; y (3) para conocer la realidad social emplean métodos y técnicas de investigación cuantitativas o cualitativas.

Estos criterios de comprobación son enfrentados por las nociones criminológicas, que sugieren una ubicación dentro de las ciencias empírico-sociales; en consecuencia, el discurso criminológico deberá ser contrastado en las dos categorías de científico y empírico-social.

La primera categoría es superada en base a que la Criminología: (1) al pretender explicar sus objetos de estudios (delito, delincuente, víctima y procesos de criminalización) da a conocer causas o motivos de hechos, estados o realidades; (2) en el afán de determinar con exactitud su campo de estudio, problematiza sus objetos con la finalidad de obtener una mayor pulcritud conceptual; (3) posee una variada gama de conceptos abstractos para explicar cosas distintas y particulares, como son: delito, delincuencia, reacción social, política criminal, entre otros; (4) somete a comprobación, de manera minuciosa y reiterativa, las afirmaciones surgidas en su seno, por ejemplo: las teorías criminológicas propuestas a lo largo de su historia, durante muchos años han sido objeto de investigaciones destinadas a verificarlas o falsearlas ${ }^{34}$; (5) por su carácter multi o interdisciplinar los conocimientos emanados de esta área pueden fácilmente intercalarse en otras disciplinas con las cuales comparten algunos supuestos básicos; y (6) pese a ser discutida su neutralidad, en el sentido de estar condicionado su estudio por grupos de poder que establecen las normas dentro de una sociedad ${ }^{35}$, estos ejercicios del poder, mediante proceso de etiquetamiento de actos y personas como criminales (criminalización), tienden a reflejar diferentes poderes e intereses particulares dentro de una sociedad, lo cual más que manipular amplía los horizontes de investigación ${ }^{36}$.

Por su parte, la segunda categoría es satisfecha por el conocimiento criminológico que: (1) es esencialmente fáctico, como se ha sostenido y desarrollado en el apartado II; (2) propone explicar los hechos objeto de estudio (fenómeno delictivo) formulando propuestas explicativas de su acaecimiento (teorías criminológicas), para intentar comprender su surgimiento o prevenir su ocurrencia, para luego ser sometidas a comprobación detallada; (3) pretende prestar utilidad, principalmente en la prevención de los delitos y en el sistema penal ${ }^{37}$; (4) emplea en sus investigaciones

4 Cid y Larrauri, Teorías Criminológicas, op. cit., pág. 254.

35 Coleman \& Norris, Introducing Criminology, op. cit., pág 7.

36 Newburn, Criminology, op. cit., pág. 8.

37 Cid y Larrauri, Teorías Criminológicas, op. cit., págs. 2-23. 
métodos cuantitativos y cualitativos (como se señala en el apartado II), para plasmar de la manera más acabada sus objetos de estudio; (5) solo cobra sentido en la medida que reconoce la existencia de una realidad externa susceptible de ser conocida; y (6) posee un desarrollo histórico estrechamente vinculado y similar al experimentado por los marcos de referencia de las ciencias sociales, pues adquiere autonomía bajo el amparo de la filosofía positivista, adhiriendo a sus postulados (positivismo biológico), luego, manteniéndose dentro del mismo marco, se matizan algunos discursos para dar repuestas más precisas a los objetos de estudio (escuelas sociológicas) y, finalmente, se produce un cambio de orientación respecto de lo anterior, dominado por el paradigma causal (teoría del etiquetamiento).

Para finalizar y entregar una mayor profundidad, es posible agregar a la contrastación anterior, los argumentos sostenidos por los criminólogos (en sus manuales o libros de textos) para justificar el estatus científico de la disciplina que desarrollan. Estos fundamentos aluden a que la Criminología: (1) posee un objeto de conocimiento, un métodos de estudio y un sólido cuerpo doctrinal sobre el fenómeno delictivo, compuesto por información válida, fiable y contrastable ${ }^{38} ;(2)$ sus seguidores adhieren estrictamente al método científico, construyendo así un conocimiento criminológico desde interrelaciones lógicas, bases teóricas y testeando empíricamente las hipótesis que son materia de nuevos análisis, mediante métodos cuantitativos o cualitativos ${ }^{39}$; y (3) utiliza métodos de investigación prestados de otras ciencias sociales y desarrolla los propios, disponiendo de un gran conjunto de conocimientos sobre la delincuencia y sobre su control, adquiridos de múltiples investigaciones empíricas y del tema de estudio preocupa a cualquier sociedad, generando gran interés público ${ }^{40}$.

En base a todo lo anteriormente señalado, con salvedades y recaudos, es posible dar una respuesta afirmativa a la pregunta ¿es la Criminología un Ciencia?

\section{Conclusión}

Pese a los esfuerzos realizados en este trabajo por explicitar las dificultades a las cuales se enfrentan los investigadores al momento de determinar el estatus científico del saber criminológico y la propuesta de determinación sugerida, quedan aún demasiadas interrogantes por resolver, todas ellas capaces de dar un brusco giro a lo señalado anteriormente.

\footnotetext{
38 García-Pablos, Criminología: Una introducción a sus fundamentos teóricos, op. cit., pág. 36.

39 Lanier \& Stuart, Essential Criminology, op. cit., pág. 17; y Serrano, Introducción a la Criminología, op. cit., págs. 34-52.

40 Garrido, Stangeland y Redondo, Principios de Criminología, op. cit., págs. 55-59.
} 
Algunas de estas preguntas se vinculan principalmente con el aspecto multi o interdisciplinar de la criminología, y pueden formularse: si la Criminología se basa en diferentes disciplinas, ¿puede ella reivindicar tal condición? ${ }^{41}$, o la Criminología al ser parasitaria de otras disciplinas, ¿puede llamarse por sí misma?, o sería mejor considerarla como un campo de estudio más que una disciplina ${ }^{42}$; entonces, ¿es la Criminología simplemente la intromisión de diversas disciplinas en una materia particular? Estos cuestionamientos aumentan el desconcierto, pero aquello no debe nublar la perspectiva, y quizás sea más promisorio adoptar la posición de Radzinowics, para quien la Criminología no es una disciplina principal y autónoma, pues solo entra en la provincias de muchas otras ciencias versadas en la naturaleza humana y la sociedad; pero no por ello se debe olvidar que "... En alguna forma, muchas de las dudas que la Criminología ha fermentado para desafiar el statu quo son tan importantes como las explicaciones que ha exitosamente proporcionado..." ${ }^{43}$.

\section{Bibliografía}

Bunge, M. (1985). “¿Qué es la ciencia?” en M. Bunge, La ciencia su método y filosofía (págs. 8-36). Buenos Aires: Ediciones Siglo Veinte.

Cid Moliné, J. y Larrauri Pijoan, E. (2001). Teorías Criminológicas. Barcelona: Bosch.

Coleman, C. \& Norris, C. (2000). Introducing Criminology. Portland: Willan Publishing.

Corbetta, P. (2003). Metodología y técnicas de investigación social (M. Díaz Ugarte, y S. Díaz Ugarte, Trads.). Madrid: McGraw-Hill.

García-Pablos de Molina, A. (2005). Criminología: Una introducción a sus fundamentos teóricos ( $5^{\mathrm{a}}$ ed.). Valencia: Tirant lo Blanch.

Garrido, V., Stangeland, P. y Redondo, S. (2006). Principios de Criminología. Valencia: Tirant lo Blanch.

KAISER, G. (1988). Introducción a la Criminología (7a ed.). (N. J. Rodríguez y J. M. Rodríguez Devesa, Trads.). Madrid: Dykinson.

Lanier, M. M. \& Stuart, H. (2010). Essential Criminology (3a ed.). Philadelphia: Westview Press.

NAGEL, E. (1989). "La ciencia y el sentido común" en E. Nagel, La estructura de la ciencia (N. Miguez, Trad., págs. 15-26). Barcelona: Paidós.

\footnotetext{
Newburn, Criminology, op. cit., pág. 5.

2 Coleman \& Norris, Introducing Criminology, op. cit., pág 15.

43 Radzinowics, S. L. (1999). "A brief for Criminology" en S. L. Radzinowicz, Adventures in Criminology (págs. 440-469). London: Routledge.
} 
Newburn, T. (2007). Criminology. Portland: Willan Publishing.

Ove Hansson, S. (3 de septiembre de 2008). Sciencie and Pseudo-Science. Recuperado el 20 de marzo de 2010, de Stanford Encyclopedia of Philosophy: http://plato.stanford.edu/entries/pseudo-science/

Plantinga, A. (20 de febrero de 2007). Religion and Science. Recuperado el 1 de abril de 2010, de Stanford Encyclopedia of Philosophy: http://plato.stanford.edu/entries/religion-science/

Radzinowics, S. L. (1999). "A brief for Criminology" en S. L. Radzinowicz, Adventures in Criminology (págs. 440-469). London: Routledge.

Roldán BARBERO, H. (2009). Introducción a la investigación criminológica. Granada: Editorial COMARES.

Serrano Maíllo, A. (2008). Introducción a la Criminología (5ª ed.). Madrid: Dykinson.

Tierney, J. (2006). Criminology: theory and context ( $2^{\mathrm{a}} \mathrm{ed}$.). London: Pearson Education Limited. 



\section{ARTíCULOS CIENTÍFICOS}





\title{
EL ROL DE LA COMISIÓN DE DEFENSA DE LA CÁMARA DE DIPUTADOS EN LA FORMULACIÓN DE LA POLÍTICA DE DEFENSA ${ }^{1}$
}

\author{
Jaime Baeza Freer \\ UnIVERSIDAD DE CHILE \\ ANDRÉS DOCKENDORFF VALDÉS \\ Academia Nacional de Estudios Políticos y Estratégicos de Chile (ANePe) \\ Natalia Vargas Palacios \\ UNIVERSIDAD DE CHILE
}

Fecha de recepción: 17 de mayo de 2010.

Fecha de aceptación: 01 de junio de 2010.

\begin{abstract}
Resumen
Este estudio examina el rol de la Comisión de Defensa de la Cámara de Diputados en el proceso de toma de decisión en materias de Seguridad y Defensa (Policy Making Process -PMP- en inglés). En este contexto, las premisas de este estudio guardan relación con las atribuciones de estas comisiones, que van más allá de la mera aprobación presupuestaria y proyectos para convertirlas en ley, sino que, además, otras actividades centrales para los intereses de sus miembros en materias tales como la supervisión de las decisiones del gobierno en materia de Defensa, como asimismo su relación directa con las Fuerzas Armadas, considerando que cada diputado y senador pueden influir en el desarrollo de políticas públicas de cada rama castrense.
\end{abstract}

Palabras clave: Comisiones de Defensa, Cámara de Diputados, Fuerzas Armadas-Chile

\begin{abstract}
This research examines the role played by the Defense Committee at the Chilean House of Deputies in regards to the decision making process known Policy Making Process (PMP). In this context, the study is based on the assumption that the Committee has more attributions than producing legislation, budget approving and similar bills, but also other key political activities. These other issues are related to supervising government's decisions in the Defense sector, as well as a direct relationship with each branch of the Armed Forces, being considered the possibility of direct influence of each Congressman in each of the service.
\end{abstract}

Key words: Defense Committee, House of Deputies, Armed Forces-Chile

Para correo y consultas a Jaime Baeza jbaezaf@u.uchile.cl o Andrés Dockendorff dockendorf@gmail. com. Agradecemos el apoyo financiero de ANEPE y especialmente de don Víctor Guzmán Martínez. Este es la versión corregida de un trabajo homónimo presentado ante el IX Congreso Chileno de Ciencia Política, noviembre de 2010. 


\section{Introducción}

Hasta ahora, existen muy pocos estudios acerca de las comisiones de defensa en Chile y, principalmente, de carácter descriptivo. Entre estos ejemplos es posible encontrar el trabajo de Contreras, Polloni y Ortiz (2001) que produjo una visión panorámica acerca de las atribuciones constitucionales y legales que rigen su accionar, aunque desactualizado producto de las reformas constitucionales de 2005. En este mismo sentido, la Red Sudamericana de Seguridad (RESDAL, 2008) produjo un volumen describiendo el funcionamiento y el marco legal de varias comisiones de defensa en el continente sudamericano. Dentro de su trabajo, atención han puesto en las principales características acerca de la periodicidad de las sesiones y cuáles son las atribuciones que diputados y senadores pueden ejercer.

En el contexto mencionado, este estudio innova en términos de proponer nuevas respuestas acerca de los incentivos que entrega el sistema para que los miembros del Congreso quieran ser parte de las comisiones de defensa, y cómo el PMP es desarrollado, en tanto también analiza las prioridades políticas de sus miembros. A priori, parece ser que más relevante que la mera formulación de proyectos de ley, están más interesados en la supervisión de la política de defensa, modificando los proyectos del Ejecutivo y en interrelación directa con las Fuerzas Armadas.

La experiencia comparada enseña que la capacidad de oversight que tienen las comisiones de defensa sobre las Fuerzas Armadas y el Ejecutivo en otras partes del mundo les permite pasar de un mero contrapeso de poderes, a constituirse en actores fundamentales en la formulación de las políticas de defensa. Para cumplir este fin, se requiere, junto con el conocimiento de la actividad de los miembros de la Comisión, que son especialistas en asuntos legislativos y no necesariamente especialistas en defensa, contar con una cuantificación certera de la actividad realizada en términos de su consecuencias para todo el sector y la población, como asimismo, la indispensable generación de un cuerpo civil de asesores que puedan ayudar de manera profesional en la formulación de dicha política, cuestión clave para una institución como la ANEPE.

\section{Antecedentes para el debate}

El Libro de la Defensa de Chile publicado en 2010 señala que en ambas cámaras del Honorable Congreso Nacional existirán comisiones de defensa, las que tienen entre otras funciones "la de analizar e informar al respectivo plenario todos los proyectos de ley relativos a la defensa nacional, en general, y a las Fuerzas Armadas en particular" (2010: 119). Además, el documento sostiene que las cámaras concurren a la aprobación presupuestaria del sector, amén de poder declararse en estado de asamblea en caso de guerra exterior y, a su vez, el Senado autorizar o denegar la entrada 
de tropas extranjeras al interior de la República, como asimismo, la salida de tropas chilenas al exterior (Ibíd.: 119).

Si bien este documento oficial da cuenta de la labor en términos formales de las actividades de las comisiones de Defensa de la Honorable Cámara de Diputados y del Honorable Senado de la República, pareciera ser definiciones de orden más bien jurídico formal, en tanto lo que determinan la Constitución Política de la República, como asimismo otras instituciones legales tales como la Ley Orgánica del H. Congreso Nacional, entre otras. Sin embargo, esta definición dice poco acerca de la vida interna de ambas comisiones y cuál es su verdadera influencia en la construcción y funcionamiento de la política nacional de defensa. Si bien la vida diaria de las comisiones pasa también por lo Legislativo, este proyecto está interesado en la actividad prelegislativa y no legislativa que realiza y que impacta en el desarrollo de la actividad de seguridad y defensa del país, englobando dicha tarea en el concepto de Policy Making Process (PMP). Junto con el gobierno y los partidos políticos, el cuerpo legislativo es un actor crucial del PMP, ya que se espera que capten las demandas, problemas y necesidades de los ciudadanos, formulando y/o aprobando políticas ad hoc (Stein et al., 2006; Stein y Tommasi, 2006). PMP en democracia.

Los sistemas de formulación de políticas públicas -que reconoce crecientemente complejos- están asociados íntimamente a la gobernabilidad democrática (Peters, 2003). El estudio comparado de Formulación de Políticas Públicas (PFP) ha sido promovido por la línea de investigación desarrollada por el Banco Interamericano de Desarrollo (BID). Esta preocupación se ha traducido en diversos documentos de trabajo y publicaciones. El libro La Política de las Políticas Públicas (2006) constituye el esfuerzo más acabado por relevar, a escala comparada, la importancia de estudiar este asunto en América Latina. En ese trabajo se define el PFP como;

"Un proceso de negociaciones e intercambios (o transacciones) entre los actores políticos", que "(...) engloba todo el proceso de discusión, aprobación e implementación de las políticas públicas" (Stein et al., 2006: 18).

Diversos actores o jugadores participan interactivamente del PFP en distintos escenarios formales (legislatura y gabinete) e informales (Stein et al., 2006: 18). El enfoque del BID resalta la correlación positiva que existiría entre la calidad de las políticas y los resultados (outcomes), con la capacidad de los actores para conseguir acuerdos y basar las políticas públicas en la cooperación. De la calidad del PFP de cada país dependerán: la estabilidad, adaptabilidad, coherencia, coordinación, la calidad de la implementación, la eficiencia y la orientación hacia el interés público de las políticas (Stein et al., 2006: 17). En esta perspectiva, la calidad de las políticas públicas (variable dependiente) estaría afectada por la habilidad de los actores políticos para promover y obtener resultados basados en consensos (Spiller, Stein y Tommasi, 2003). 
El estudio comparado del proceso de formulación de políticas públicas (PFP) ha sido promovido por la línea de investigación desarrollada por el Banco Interamericano de Desarrollo (BID), una preocupación que se ha traducido en diversos documentos de trabajo y publicaciones. El libro La Política de las Políticas Públicas (2006) constituye el esfuerzo más acabado por relevar, a escala comparada, la importancia de estudiar los PFP en América Latina. En este trabajo se define el PFP como: "un proceso de negociaciones e intercambios (o transacciones) entre los actores políticos", que "(...) engloba todo el proceso de discusión, aprobación e implementación de las políticas públicas" (Stein et al., 2006: 18).

Diversos actores o jugadores participan interactivamente del PFP en distintos escenarios formales (legislatura, gabinete) e informales (Stein et al., 2006: 18). El enfoque del BID resalta la correlación positiva que existiría entre la calidad de las políticas y los resultados (outcomes) con la capacidad de los actores para conseguir acuerdos y fundamentar las políticas públicas en la cooperación. De la calidad del PFP de cada país dependerán la estabilidad, adaptabilidad, coherencia, coordinación, la calidad de implementación, la eficiencia y la orientación hacia el interés público de las políticas (Stein et al., 2006: 17). Lo anterior está ligado a la capacidad de los actores (o jugadores) para obtener acuerdos de calidad que sean estables en el tiempo (Spiller, Stein y Tommasi, 2003). Desde esta perspectiva, la calidad de las políticas públicas (variable dependiente) estaría afectada por la habilidad de los actores políticos para promover y obtener outcomes basados en la cooperación y el consenso (Spiller, Stein y Tommasi, 2003).

Lo anterior no es exclusivo del enfoque del BID y de las conclusiones de los trabajos de Stein y Tommasi (2006), Spiller et al., (2003), Aninat, Londregan et al., (2006) y otros, sino que es recogido por estudiosos que han seguido de cerca procesos de formulación de políticas públicas desde la asesoría de políticas públicas en el caso chileno. Entre ellos, Eugenio Lahera tiene un juicio coincidente, ya que, en su opinión, las políticas públicas "(...) basadas en discusiones con todos los actores relevantes se acercarán más a los objetivos de bien público, al mismo tiempo tendrán el necesario apoyo sostenido de la ciudadanía. Podrán a la vez ser más comprehensivas y viables" (Lahera 2002: 31). PFP en Chile: teoría y evidencia.

En el trabajo del BID el caso chileno es destacado por la calidad de sus políticas públicas, junto a los casos brasileño y uruguayo. El informe del organismo analiza un conjunto de variables que incidirían para que en Chile exista una eficaz formulación de las políticas públicas. El trabajo desarrollado por Aninat, Londregan et al. (2006) apunta en el mismo sentido. Existen incentivos para la cooperación y la transacción en el circuito legislativo y en el proceso de políticas públicas en base a acuerdos que mejorarían la calidad de las políticas (Aninat, Londregan, Navia y Vial 2006; Aninat 2004; Boeninger 2008; Stein et al., 2006). Esta perspectiva recoge la visión promovida por los trabajos y estudios patrocinados por el BID (Stein et al., 2006; Stein y Tommasi, 2006; Spiller et al., 2003, Aninat, Londregan et al., 2006). 
La combinación de un Ejecutivo con amplia capacidad de establecer agenda y actores con capacidad de veto incentivaría la cooperación, la negociación y el acuerdo en la formulación de las políticas (Aninat 2004; Stein et al., 2006; Aninat, Londregan et al., 2006). El proceso de generación, articulación y formulación de políticas en Chile estaría determinado, entre otros factores, por la negociación y un alto grado de consenso sobre las políticas, donde el proceso de formulación de políticas se desarrolla a través de acuerdos y negociaciones entre el Ejecutivo y la oposición, lo que responde también a ciertas restricciones institucionales (por ejemplo: quórums, sistema electoral) y a la necesidad dotar de legitimidad el proceso de "hechura" de las políticas (Schmidt 2007).

De acuerdo al trabajo del BID (2006) y Aninat (2004), Chile es el país mejor evaluado de la región en cuanto a las características de sus políticas públicas (estabilidad, adaptabilidad, entre otras). A pesar del enorme poder asignado por la Constitución de la República al Presidente, el sistema chileno de formulación de políticas opera sobre la base de un conjunto de jugadores con capacidad de veto ${ }^{2,3}$. Existiría una secuencia de negociaciones y acuerdos a partir de los cuales se discuten y negocian las políticas (Stein et al., 2006; Aninat 2004).

\section{Comisiones de defensa: experiencia comparada}

Las comisiones de defensa cumplen un rol que va más allá de lo meramente legislativo. En este sentido, vale la experiencia a nivel comparado. En el caso de los regímenes parlamentarios europeos, los que en general comparten ciertas características acerca de su funcionamiento. En este sentido, un rol relevante es el concepto anglosajón de oversight en tanto Born lo considera como la permanente supervisión que realiza acerca del funcionamiento del gobierno y, en este caso, del manejo del sector defensa, la gobernanza como medida de asegurar las formas democráticas en el manejo del sector defensa y el control del sector, tanto en lo reactivo (fiscalizador) como asimismo proactivo (generación de normas que permitan el mejor funcionamiento del sector (Born, 2002: 4). La actividad de oversight no puede ser solo del Poder Ejecutivo, también el Congreso y en especial la comisión respectiva debe estar presente (USAID, 2005). Esta es una característica esencial en un sistema democrático. Como el propio autor suizo reconoce, Hitler y Stalin tenían control sobre las Fuerzas Armadas de su poder, pero carecían de todo control democrático (Born, 2002: 5). Este último punto es crucial, ya que la literatura reconoce que las relaciones cívico-militares ya no se basan únicamente en el control, sino que también en la efectividad y la eficiencia democrática del mismo (Bruneau y Matei, 2008; Bruneau, Matei y Sakoda, 2009), enfoque

Sobre los jugadores con veto y su impacto en el proceso político democrático véase Tsebelis (2002)

Sobre los jugadores con veto y su impacto en el proceso político democrático véase Tsebelis (2002). 
bajo el cual la efectividad de la supremacía civil no se mide únicamente a partir de la presencia/ausencia de posibilidad de levantamientos militares, sino a partir del rol que juegan las autoridades civiles en la formulación y definición de las políticas de defensa (Fuentes, 2008), espacio donde los congresos y sus comisiones especializadas resultan claves (Bruneau, 2005; Born, Flury y Lunn, 2003).

Entre las actividades que se encuentran en los sistemas parlamentarios europeos, Born reconoce al menos las siguientes características propias de comisiones de defensa, tales como realizar informes que involucren el parecer de los partidos de oposición o minoritarios, aprobar y modificar los proyectos de legislación que tengan que ver con seguridad y defensa, recibir información y canalizar las inquietudes en la materia que tenga la sociedad civil organizada.

La realidad europea responde a regímenes parlamentarios donde el propio gobierno reside en el Parlamento. En los regímenes presidenciales, como el nuestro, el gobierno está radicado en sede diferente del Congreso Nacional, lo que hace que además de representar las visiones de la oposición y otros grupos al interior del Parlamento, en los sistemas como el chileno la comisión cumple una función política de check and balances, de acuerdo al modelo presidencialista. En ese sentido, a pesar de la naturaleza reactiva de muchas legislaturas de América Latina, los estudiosos reconocen que las comisiones pueden hacer la diferencia en las legislaturas (Cox y Morgenstern, 2002; Morgenstern, 2002; Rivera, 1998), en la medida en que pueden afectar la estructura de incentivos (junto a la variable reelección) de las relaciones Ejecutivo-Legislativo y la capacidad de los congresos para influir en el PMP (Bejar, 2007; Morgenstern, 2002).

El Congreso chileno combina instancias de veto con otras de cooperación y negociación (Boeninger, 2007; Aninat, Londregan, Navia y Vial, 2006; Aninat, 2006; Schmidt Hebbel, 2007). En contra de algunos diagnósticos comparados excesivamente formales sobre las relaciones Ejecutivo-Legislativo en el caso chileno, la evidencia empírica sugiere que el Congreso chileno tiene una creciente influencia en el proceso decisorio (Boeninger, 2007; Huneeus y Berríos, 2004; Berríos y Gamboa, 2006; Aninat, 2006), lo que se ha ganado gracias a la mayor especialización y profesionalización y la estructuración de sistemas de asesorías competentes (Aninat, 2006; Boeninger, 2007), pero por sobre todo, al eficiente funcionamiento del sistema de comisiones, cuestión desconocida por la ciudadanía (Boeninger, 2007).

A pesar de que es débil si se lo compara con el Congreso de Estados Unidos y su poderoso sistema de comisiones, "(...) the chilean Congress is unusually profesional and technically competent by Latin American standars" (Aninat, Londregan, Navia y Vial, 2006: 31). Las comisiones legislativas juegan un rol clave en la formulación de gran parte de la legislación más relevante (Carey, 2002; Siavelis, 2002). Este aspecto, junto con la profesionalización de los legisladores y las capacidades técnicas del conjunto de la legislatura, permiten a John Carey concluir que: 
"(...) the Chilean Congress is highly professionalized- particularly for a young legislature- and that its committee system is accumulating substantial expertise, and is organized and dominated by the majority coalition. Within the comparative study of legislatures, these are all regarded as indicators of strong legislative capacity" (Carey, 2002: 222- 253).

Por otro lado, al existir correspondencia entre los ámbitos de actividad estatal y la estructura de comisiones, el grado de coordinación del Ejecutivo y el Legislativo es alto, especialmente en perspectiva comparada (Aninat, 2006; Aninat, Londregan, Navia y Vial, 2006; Stein y Tommasi, 2006; Stein et al., 2006).

La importancia de las comisiones permanentes en el sector defensa es discutido por algunos estudiosos, quienes plantean que las comisiones de defensa de ambas cámaras son entes más bien decorativos, producto de la poca preparación de sus miembros en los temas de defensa y un sistema de asesoría poco especializado en estas materias (Weeks, 2006; Valdivieso, 2009). Este trabajo pretende revisar estas conclusiones y, eventualmente, discutirlas a partir de la evidencia empírica.

De acuerdo a una corriente de la literatura, la seguridad y defensa no constituirían una prioridad para los políticos de América Latina, caracterizándose por un menor nivel de escrutinio público y debate que otras políticas públicas (Pion-Berlin y Trinkunas, 2007). Lo anterior se explicaría en función de patrón histórico asociado a Fuerzas Armadas con débiles capacidades y que se constituyen más en una amenaza para los gobiernos que para los vecinos, un entorno de relativa tranquilidad regional y la baja importancia que le asignarían los votantes (y por ende los políticos y legisladores) a la provisión de la defensa nacional (Pion-Berlin y Trinkunas, 2007). Junto a ello, existe la creencia equivocada de que las políticas de seguridad y defensa son una tarea que recae "naturalmente" en el Ejecutivo, visión desmentida por los casos históricos en Estados democráticos (Born, Fluir y Lunn, 2003). Por otra parte, en el campo de la defensa, las tareas convencionales de control, discusión y debate sectorial que ejercen las legislaturas, especialmente a través de las comisiones, se ven complejizadas producto de la considerable especialización que requieren, la naturaleza de la información que se maneja, entre otras (Van Eekelen, 2005).

El papel que desempeñan los congresos en la defensa nacional cobra mayor relevancia al asumir que las relaciones cívico militares (CMR) en la actualidad no se basan solo en el control, sino que también en la efectividad y la eficiencia (Bruneau y Matei, 2008; Bruneau, Matei y Sakoda, 2009) ${ }^{4}$. Si bien Bruneau, Matei y Sakoda

$4 \quad$ Al respecto, y en un análisis a escala del Cono Sur, Fuentes (2008) sostiene que la efectividad de la supremacía civil no se puede definir a partir de la presencia/ausencia de posibilidad de levantamientos militares, sino que términos de las definiciones constitucionales sobre el rol de las Fuerzas Armadas, el rol que juegan las autoridades civiles en la formulación y definición de las políticas de defensa y las transformaciones de la estructura de la defensa (Fuentes, 2008). 
(2009) argumentan que los Consejos de Seguridad Nacional (CSN) pueden jugar un rol clave al favorecer las relaciones cívico-militares en estas dimensiones (control, efectividad y eficiencia), en este trabajo se aborda los desafíos en materia de CMR poniendo atención en el rol de la legislatura, punto que reconoce Thomas Bruneau cuando señala que las legislaturas sirven como soporte para la trilogía control; efectividad y eficiencia, ya que

"(....) they ensure democratic civilian control by maintaining real separation of powers, controlling the budget, and excersing oversight. Diversity of political representation through elections, and the development of expertise among members and particularly their staffs, allows legislatures to improve the effectiveness of roles and missions (...) Furthermore, legislatures routinely implement an oversight function through hearings, auditing units, and inspectors general to ensure efficiency" (Bruneau, 2005: 124).

En general, en perspectiva comparada, el Poder Legislativo juega un rol central cuando se trata de establecer la supremacía civil y garantizar la gobernabilidad democrática (Born, Flury y Lunn, 2003). "Las ventajas de un accionar fluido entre el Parlamento y el sector de la defensa, debe ser vista también en lo que atañe a la implementación de normas e instancias de gestión y relacionamiento con las fuentes militares, en términos de información y comunicación para el cumplimiento de las tareas legislativas, fiscalizadoras e investigadoras, en beneficio de una mejor capacidad de gestión, control y legislación en las áreas de defensa, seguridad y agenda de política exterior" (Celi, 2003: 7). En otras palabras, la relación entre la legislatura y las Fuerzas Armadas, constituye "(...) una condición necesaria para el ejercicio democrático de su control y conducción desde políticas consensuadas y socialmente asumidas" (Celi, 2003: 7).

Todo lo anterior va ligado al papel que desempeñan, en perspectiva comparada, y cómo se desarrollarán en este las comisiones de defensa de los congresos o parlamentos.

\section{Las comisiones de defensa y su rol en democracia}

La experiencia de los congresos de América Latina indica que "(...) las comisiones hacen la diferencia en las legislaturas" (Rivera, 1998: 531), ya que afectarían "(...) la estructura de incentivos que acota el desarrollo del proceso legislativo" (Bejar, 2007: 103), en tanto son "(...) una de las variables internas más importantes que pueden determinar la capacidad de las legislaturas para influir en la elaboración de las políticas gubernamentales" (Rivera, 1998: 565). En ese sentido, "las comisiones cumplen un papel cada vez más importante en el proceso legislativo, tanto como espacio de discusión como de mejora técnica" (García y Sánchez, 2002: 33). Pero su rol no solo afecta el policy making, sino que son instrumentos ad hoc para supervisar y fiscalizar, así como para "(...) llamar la atención del gobierno sobre temas clave que 
pudieran no estar incluidos en la agenda gubernamental" (Rivera, 1998: 566). Esta influencia aumenta y es mayor en el caso de las comisiones permanentes y correspondientes a la estructura administrativa (Olson y Norton 1996, citado en Rivera, 1998)

En el caso del campo de la defensa y la seguridad, Born (2002) sostiene que, considerando la complejidad del sector, una estructura de comisiones bien desarroIlada es necesaria si el Poder Legislativo espera tener influencia real en la administración (Born, 2002).

Este ejercicio parte reconociendo que el rol de los congresos en América Latina no suele incorporarse al debate académico (Donadio, 2004). De todas formas, un diagnóstico positivo señala que las comisiones de defensa se han ido constituyendo en un aporte a las CMR, en la medida en que operan como un espacio para que interactúen civiles y militares (Follietti y Tibiletti, 2004). En la región "(...) las comisiones de defensa se convierten en el referente por excelencia al querer conjugar parlamento y defensa" (Follietti y Tibiletti, 2004: 10). "Las comisiones parlamentarias de defensa son una instancia muy importante en cuanto al procesamiento, investigación, análisis, posicionamiento y asesoría sobre la problemática", a pesar de que la responsabilidad recae en todos los legisladores (Celi, 2004: 28).

En algunos países de América Latina no existe una comisión legislativa específica que trate las materias del sector defensa. "Es una práctica común en algunos parlamentos de la región que los asuntos de seguridad y defensa sean tratados por diversos tipos de comisiones, denominadas de seguridad nacional, de Fuerzas Armadas, de asuntos internacionales, de relaciones exteriores, con lo cual se vuelven imprecisas sus funciones y se debilita el posicionamiento y el tratamiento particular de la problemática" (Celi, 2004: 29). Al apreciar las disposiciones formales establecidas en la Constitución de países como Venezuela, Bolivia, Perú y Colombia, Rial (2004) concluye que a pesar de que "(...) el predominio civil en la conducción de la defensa nacional muestra avances, (....) el tratamiento de los congresos es mínimo" (Rial, 2004: 16). En los casos señalados "Suele ser más clara la atribución de potestades al Ejecutivo, pero aun así permanece un gran margen de discrecionalidad", asociado a dos cuestiones básicas: la capacidad efectiva con que cuenta los ejecutivos en materia de políticas de defensa y relaciones cívico-militares y el papel real que tienen las legislaturas en el proceso político de estos países (Rial, 2004: 16).

Alemán y Pachón (2008) argumentan, a partir del estudio comparado de los casos de Chile y Colombia, que las comisiones de conciliación (Comisión Mixta en la nomenclatura legal chilena) tienen una "posición privilegiado desde la que influyen en el contenido de las propuestas de ley", ya que rara vez sus propuesta son votadas negativamente (p. 3). 
Tabla $N^{0} 1$

Comisiones de Defensa en América Latina

\begin{tabular}{|c|c|c|c|}
\hline País & Cámara de Diputados & Senado & Unicameral \\
\hline Argentina & $\begin{array}{l}\text { Comisión de Defensa } \\
\text { Nacional }\end{array}$ & $\begin{array}{l}\text { Comisión de Defensa } \\
\text { Nacional }\end{array}$ & \\
\hline Bolivia & $\begin{array}{l}\text { Comisión de Defensa y } \\
\text { Fuerzas Armadas }\end{array}$ & $\begin{array}{l}\text { Comisión de Gobierno, } \\
\text { Defensa, Policía Nacional } \\
\text { y Lucha contra el tráfico } \\
\text { ilícito de drogas. }\end{array}$ & \\
\hline Brasil & $\begin{array}{l}\text { Comisión de Relaciones } \\
\text { Exteriores y Defensa } \\
\text { Nacional }\end{array}$ & $\begin{array}{l}\text { Comisión de Relaciones } \\
\text { Exteriores y Defensa } \\
\text { Nacional }\end{array}$ & \\
\hline Chile & $\begin{array}{l}\text { Comisión de Defensa } \\
\text { Nacional }\end{array}$ & $\begin{array}{l}\text { Comisión de Defensa } \\
\text { Nacional }\end{array}$ & \\
\hline Colombia & Comisión Segunda & Comisión Segunda & \\
\hline El Salvador & & & Comisión de Defensa \\
\hline Guatemala & & & $\begin{array}{l}\text { Comisión de Defensa } \\
\text { Nacional }\end{array}$ \\
\hline Honduras & & & $\begin{array}{l}\text { Comisión de Defensa } \\
\text { Nacional }\end{array}$ \\
\hline México & $\begin{array}{l}\text { Comisión de Defensa } \\
\text { Nacional }\end{array}$ & $\begin{array}{l}\text { Comisión de Defensa } \\
\text { Nacional }\end{array}$ & \\
\hline Nicaragua & & & $\begin{array}{l}\text { Comisión de la Paz, } \\
\text { Defensa, Gobernación y } \\
\text { Derechos Humanos }\end{array}$ \\
\hline Paraguay & $\begin{array}{l}\text { Comisión de Defensa } \\
\text { Nacional, Seguridad y } \\
\text { Orden Interno }\end{array}$ & $\begin{array}{l}\text { Comisión de Asuntos } \\
\text { Constitucionales, De- } \\
\text { fensa Nacional y Fuerza } \\
\text { Pública }\end{array}$ & \\
\hline Perú & & & $\begin{array}{l}\text { Comisión de Defen- } \\
\text { sa Nacional, Orden } \\
\text { Interno, Inteligencia, } \\
\text { Desarrollo Alternativo y } \\
\text { Lucha contra las Drogas }\end{array}$ \\
\hline $\begin{array}{l}\text { República } \\
\text { Dominicana }\end{array}$ & $\begin{array}{l}\text { Comisión de Seguridad y } \\
\text { Defensa Nacional }\end{array}$ & $\begin{array}{l}\text { Comisión de Defensa y } \\
\text { Seguridad Nacional }\end{array}$ & \\
\hline Uruguay & $\begin{array}{l}\text { Comisión de Defensa } \\
\text { Nacional }\end{array}$ & $\begin{array}{l}\text { Comisión de Defensa } \\
\text { Nacional }\end{array}$ & \\
\hline Venezuela & & & $\begin{array}{l}\text { Comisión de Defensa y } \\
\text { Seguridad }\end{array}$ \\
\hline
\end{tabular}

Fuente: RESDAL 2008. Atlas Comparativo de la Defensa en América Latina. www.resdal.org. 


\section{Funcionamiento y rol de las comisiones de defensa en Chile}

\section{Las comisiones permanentes: estructura y funciones}

De acuerdo al Reglamento de la Cámara de Diputados, existen tres tipos de comisiones: permanentes, unidas, especiales, mixtas e investigadoras. Existen 24 comi-

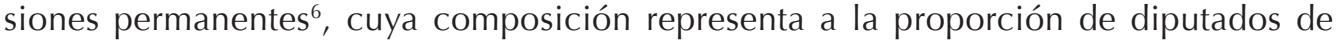
cada partido político.

En el funcionamiento del Congreso, las comisiones legislativas de la Cámara de Diputados son grupos de trabajo conformados por 13 diputados cuyo objetivo: "(...) es permitir el estudio detallado de los proyectos de ley y demás materias sometidas a conocimiento de la Corporación, usualmente se recibe la opinión de expertos en la materia de que se trate y se ofrecen audiencias a organizaciones de la sociedad civil interesadas en el tema" (www.bcn.cl). Las comisiones reciben los proyectos de ley y las materias que correspondan a su especialidad. Para dicho efecto "podrán solicitar la comparecencia de funcionarios que estén en condiciones de ilustrar sus debates y hacerse asesorar por cualquier especialista en la materia respectiva y solicitar informar u oír a las instituciones y personas que estime conveniente" (Reglamento de la Cámara de Diputados, p. 51). La relación de las comisiones con la ciudadanía está formalizada en la figura de las jornadas temáticas.

La discusión de los proyectos de ley (mensajes y mociones) se realiza en las comisiones permanentes de la Cámara de Diputados y el Senado, en correspondencia a las áreas o campos de la actividad gubernamental. Los proyectos son discutidos en general y en particular bajo un riguroso análisis de los legisladores de la comisión. En este proceso, la comisión invita a las sesiones de la misma a expertos y representantes del Ejecutivo relacionados con la materia en discusión. Los miembros de la comisión pueden presentar indicaciones modificatorias, pero siempre en materias que no sean de iniciativa exclusiva del Presidente y en referencia a las ideas matrices del proyecto en cuestión (Boeninger, 2007: 65). En ese sentido, la mayor parte del trabajo legislativo se realizaría en las comisiones legislativas, donde se votan artículo por artículo los proyectos, luego de que es aprobada la idea de legislar (Boeninger, 2007). Al existir correspondencia entre los ámbitos de actividad estatal y la estructura de comisiones,

6 De Gobierno Interior y Regionalización; de Relaciones Exteriores, Asuntos Parlamentarios e Integración Latinoamericana; de Constitución, Legislación y Justicia; de Educación, Deportes y Recreación, de Hacienda, de Defensa Nacional, de Obras Públicas, Transporte y Telecomunicaciones; de Agricultura, Silvicultura y Desarrollo Rural; de Recursos Naturales, Bienes Nacionales y Medio Ambiente; de Salud; de Trabajo y Seguridad Social; de Minería y Energía; de Economía, Fomento y Desarrollo; de la Vivienda y Desarrollo Urbano, de Derechos Humanos, Nacionalidad y Ciudadanía, de Familia, de Ciencias y Tecnología, de Pesca, Acuicultura e Intereses Marítimos, de la Micro, Pequeña y Mediana Empresa, de Zonas Extremas, de Seguridad Ciudadana, de la Cultura y de las Artes, de la Superación de la Pobreza, Planificación y Desarrollo Social. 
el grado de coordinación del Ejecutivo y el Legislativo es alto, especialmente en perspectiva comparada (Aninat, 2006; BID, 2006).

A través de sus respectivos reglamentos la cámara baja y el Senado dan forma al sistema de comisiones permanentes a las que les corresponde el trabajo de informar los proyectos de ley que la sala somete a su consideración (LOC del Congreso Nacional, Art. 17). Las dos cámaras cuentan con una Comisión de Hacienda, que debe conocer todos los proyectos que involucren componentes de materia presupuestaria o financiera.

¿Qué importancia tiene el sistema de comisiones dispuesto en la institucionalidad legislativa chilena? La discusión de los proyectos de ley (mensajes y mociones) se realiza en las comisiones permanentes de la Cámara de Diputados y el Senado, en correspondencia a las áreas o campos de la actividad gubernamental. Los proyectos son discutidos en general y en particular bajo un riguroso análisis de los legisladores de la comisión. En este proceso, la comisión invita a las sesiones de la misma a expertos y representantes del Ejecutivo relacionados con la materia en discusión (Boeninger, 2007: 65).

Los miembros de la Comisión pueden presentar indicaciones modificatorias, pero siempre en materias que no sean de iniciativa exclusiva del Presidente y en referencia a las ideas matrices del proyecto en cuestión (Boeninger, 2007: 65). La Ley Orgánica Constitucional del Congreso Nacional establece que los proyectos de ley que estén en su primer o segundo trámite constitucional, así como las observaciones realizadas por el Presidente de la República, deben ser informadas por la comisión permanente respectiva (Art. 21). Las comisiones reúnen la información que requieren para discutir los proyectos, para lo cual podrán requerir la asistencia de funcionarios que puedan "(...) ilustrar sus debates, hacerse asesorar por cualquier especialista en la materia respectiva y solicitar informes u oír a las instituciones y personas que estime conveniente" (LOC Congreso Nacional, Art. 22).

De acuerdo al Reglamento de la Cámara de Diputados, existen diferentes tipos de comisiones: permanentes, unidas, especiales, mixtas e investigadoras. Las comisiones especiales son creadas por acuerdo de la Cámara y tienen carácter temporal, formándose para estudiar una legislación o proyecto específico o recopilar información necesaria. Las comisiones investigadoras son organismos colegiados para el ejercicio de las funciones fiscalizadoras de la Cámara de Diputados, cuya competencia será fijada en su acuerdo constituyente, el que además establecerá el plazo que le corresponderá trabajar (Reglamento de la Cámara de Diputados, Art 297-300). Las comisiones unidas corresponden al trabajo conjunto de dos o más comisiones, que podrán abocarse unidas al examen de un asunto determinado (Reglamento de la Cámara de 
Diputados, Art 228). Existen 24 comisiones permanentes ${ }^{7}$, cuya composición representa a la proporción de diputados de cada partido político. Los miembros específicos de las comisiones son elegidos por la Cámara luego de una propuesta realizada por la mesa.

Las comisiones permanentes de la Cámara de Diputados son grupos de trabajo conformados por 13 diputados cuyo objetivo: "(...) es permitir el estudio detallado de los proyectos de ley y demás materias sometidas a conocimiento de la Corporación, usualmente se recibe la opinión de expertos en la materia de que se trate y se ofrecen audiencias a organizaciones de la sociedad civil interesadas en el tema" (www.bcn.cl). Las comisiones reciben los proyectos de ley y las materias que correspondan a su especialidad. Para dicho efecto, "podrán solicitar la comparecencia de funcionarios que estén en condiciones de ilustrar sus debates y hacerse asesorar por cualquier especialista en la materia respectiva y solicitar informar u oír a las instituciones y personas que estime conveniente" (Reglamento de la Cámara de Diputados, Art. 217). La relación de las comisiones con la ciudadanía está formalizada en la figura de las jornadas temáticas.

Por su parte, el Senado cuenta con 20 comisiones permanentes ${ }^{8}$. Las comisiones permanentes de la cámara alta, al igual que las especiales, estarán compuestas por 5 senadores. Cada uno de los 38 miembros del Senado debe pertenecer al menos a una de las 20 comisiones permanentes. Se podrán encomendar el estudio de un asunto o proyecto a dos o más comisiones. Tanto los proyectos de ley, ya sea que estén en primer o segundo trámite constitucional, como las observaciones del Presidente de la República, deberán pasar a la comisión respectiva (Reglamento del Senado, Art. 27-36).

7 De Gobierno Interior y Regionalización; de Relaciones Exteriores, Asuntos Parlamentarios e Integración Latinoamericana; de Constitución, Legislación y Justicia; de Educación, Deportes y Recreación, de Hacienda, de Defensa Nacional, de Obras Públicas, Transporte y Telecomunicaciones; de Agricultura, Silvicultura y Desarrollo Rural; de Recursos Naturales, Bienes Nacionales y Medio Ambiente; de Salud; de Trabajo y Seguridad Social; de Minería y Energía; de Economía, Fomento y Desarrollo; de la Vivienda y Desarrollo Urbano, de Derechos Humanos, Nacionalidad y Ciudadanía, de Familia, de Ciencias y Tecnología, de Pesca, Acuicultura e Intereses Marítimos, de la Micro, Pequeña y Mediana Empresa, de Zonas Extremas, de Seguridad Ciudadana, de la Cultura y de las Artes, de la Superación de la Pobreza, Planificación y Desarrollo Social.

8 De Gobierno, Descentralización y Regionalización; de Relaciones Exteriores; de Constitución, Legislación, Justicia y Reglamento; de Economía; de Hacienda; de Educación, Cultura, Ciencia y Tecnología; de Defensa Nacional; de Obras Públicas; de Agricultura; de Medio Ambiente y Bienes Nacionales; de Trabajo y Previsión Social; de Salud; de Minería y Energía; de Vivienda y Urbanismo; de Transporte y Telecomunicaciones; de Derechos Humanos, Nacionalidad y Ciudadanía; de Intereses Marítimos, Pesca y Agricultura; de Régimen Interior; Revisora de Cuentas; de Ética y Transparencia del Senado. 


\section{La Comisión de Defensa de la Cámara de Diputados en el periodo 2006-2010}

"La existencia de un fuerte presidencialismo no impide la existencia de una relación fluida y constructiva entre las ramas de las Fuerzas Armadas con el Congreso. En efecto, al revisar las normas en esta materia, aparece con nitidez un conjunto de alternativas procesales que permiten establecer adecuados lazos entre los entes, los que permiten al poder legislativo cumplir con las labores para las que fue creado, y dentro de los parámetros normales en los que se inscribe una sociedad democrática" (Polloni, Contreras y Ortiz, 2001: 63). Esta fluidez que existiría en cuanto a los intercambios entre el Poder Legislativo y las Fuerzas Armadas se diluye cuando entramos en el campo de la asignación de los recursos. En cuanto a la discusión presupuestaria, "(...) la labor del Congreso se ve limitada a un rol prácticamente notarial. Otra está marcada por la falta de atribuciones del Congreso en materia de disponer de las fuerzas de aire, mar y tierra, organizarlas y distribuirlas de acuerdo con las necesidades de la seguridad nacional, aspecto que la Constitución entrega en forma exclusiva al Presidente" (Polloni et al., 2001: 71).

Gregory Weeks sostiene de que a pesar de que tanto la Cámara de Diputados como el Senado en Chile tienen comisiones de Defensa:

"(...) they are neither well staffed not particularly influential. There is no permanent staff anywhere within the congressional structure with the expertise on defense issues. Any member of Congress without prior knowledge of such issues must find his or her own resources, and in practice relatively few members do so" (Weeks, 2006: 34).

En general, la asamblea chilena jugaría un rol particularmente decorativo en la formulación de las políticas de relaciones exteriores y defensa (Valdivieso, 2009), donde el control de la agenda sería aún mayor. "Al contrario de lo pasa en otras áreas, la relación del Ejecutivo con la Comisión de Defensa es ocasional, y no cuenta con mecanismos institucionalizados de conexión con el parlamento". Mientras que el Ministerio de Relaciones Exteriores cuenta con una oficina de enlace parlamentario, el Ministerio de Defensa no tiene una estructura similar (Veloso, 2004: 105). A pesar de ello, existe una visión más positiva relativa al Congreso, y al rol que podría desempeñar en el PMP.

"All the backgrounds and information indicate that the Chilean National Congress will be able to have more proactive role in foreign policies and national defense, without infringing upon the prerogatives of the executive power" (Valdivieso, 2009: 29). "Members of parliament have the legal mechanism, the administratives and the statutory to access the relevant information on foreign affairs and national defense" (Valdivieso, 2009: 29). 
Tabla No 2

Perfil miembros Comisión de Defensa Nacional 2006- 2009

\begin{tabular}{|c|c|c|c|}
\hline Miembro Comisión & Partido & Profesión & $\begin{array}{l}\text { Experiencia previa en } \\
\text { Comisión de Defensa }\end{array}$ \\
\hline Iván Paredes & PS & Empresario & NO \\
\hline Alberto Cardemil H. & Ind. & Abogado & Sí \\
\hline Sergio Correa de la Cerda & UDI & Agricultor & Sí \\
\hline María Angélica Cristi Marfil & UDI & Socióloga & Sí \\
\hline Eduardo Díaz Del Río & PRI & Licenciado en Derecho & NO \\
\hline Renán Fuentealba V. & PDC & Abogado & Sí \\
\hline Patricio Hales D. & PPD & Arquitecto & Sí \\
\hline Roberto León & PDC & Abogado & Sí \\
\hline Rosauro Martínez Labbé & RN & Agricultor & $\mathrm{NO}$ \\
\hline José Pérez Arriagada & PRSD & Técnico Agrícola & Sí \\
\hline Jorge Tarud D. & PPD & Ejercicio libre & Sí \\
\hline Jorge Ulloa. A. & UDI & Profesor de Historia & NO \\
\hline Ignacio Urrutia B. & UDI & Agricultor & NO \\
\hline
\end{tabular}

Fuente: Elaboración propia en base a la información disponible en www.bcn.cl

La Tabla 2 muestra cierto indicador de especialización en materia de defensa de los diputados integrantes de la Comisión en el periodo 2006- 2010. Como se aprecia, 8 de los 13 integrantes de esa instancia tenían experiencia previa en la Comisión de Defensa. Tal como lo reconoce la literatura, la permanencia en una comisión es un poderoso indicador de la capacidad de los legisladores para influir en el PMP. Ello, tanto por su especialización en materia de defensa como por la mayor "fluidez" de los intercambios con el sector defensa (Ejecutivo, burocracia, FF.AA.).

¿Qué actividades desarrolla principalmente la Comisión de Defensa de la cámara baja? La revisión de las actas de sesión de la Comisión entre 2006 y 2009 da cuenta del conjunto de tareas en las que concentra su trabajo esta instancia especializada. Como se aprecia en la Tabla $N^{\circ} 3$, el trabajo de la Comisión puede agruparse en tres categorías: legislativa, fiscalización, intercambios con la sociedad civil y relaciones cívico-militares. La subcategoría "materia legislativa" muestra una alta frecuencia dentro de las actividades que desarrolla la Comisión en el periodo 2006-2010, junto con "estudio legislativo". Ahora, la cantidad de proyectos de ley tramitados por la Comisión en este periodo no es muy alta. Solo 4 mensajes y 7 mociones fueron tratados en la tabla de la Comisión. 
Tabla No 3

Frecuencia de actividades Comisión de Defensa Cámara de Diputados

\begin{tabular}{|c|c|c|c|}
\hline Legislativa & Fiscalización & $\begin{array}{l}\text { Intercambio sociedad } \\
\text { civil }\end{array}$ & $\begin{array}{l}\text { Relaciones cívico } \\
\text { militares }\end{array}$ \\
\hline $\begin{array}{l}\text { - Materia Legislativa } \\
(60) \\
\text { - Estudio Legislativo } \\
\text { (5) } \\
\text { - Mensaje tramitados } \\
\text { por la Comisión (4) } \\
\text { - Mociones tratadas } \\
\text { por la Comisión (7) } \\
\text { - Aprobación } \\
\text { proyecto de ley (6) } \\
\text { - Aprobaciones } \\
\text { legislativas parciales } \\
\text { (2) }\end{array}$ & $\begin{array}{l}\text { - Citación } \\
\text { Subsecretaría de } \\
\text { Carabineros (1) } \\
\text { - Subsecretaría Policía } \\
\text { Civil (1) } \\
\text { - Oficio Legislativo- } \\
\text { Ejecutivo (24) } \\
\text { - Oficio Ejecutivo- } \\
\text { Legislativo (47) } \\
\text { - Invitación a otras } \\
\text { autoridades del Estado } \\
\text { de Chile (no gabinete) } \\
\text { (28) } \\
\text { - Oficio Comisión- } \\
\text { Contraloría (1) } \\
\text { - Requiere } \\
\text { información a las } \\
\text { FF.AA. (25) } \\
\text { - Creación comisión } \\
\text { investigadora (1) }\end{array}$ & $\begin{array}{l}\text { - Jornada Temática (1) } \\
\text { - Audiencia Pública } \\
\text { (1) } \\
\text { - Invitación Think } \\
\text { Tanks (4) } \\
\text { - Intercambio } \\
\text { Internacional (7) }\end{array}$ & $\begin{array}{l}\text { - Citaciones al } \\
\text { Ministro de Defensa } \\
\text { (18) } \\
\text { - Citación } \\
\text { Subsecretaría de } \\
\text { Guerra (11) } \\
\text { - Citación } \\
\text { Subsecretaría de } \\
\text { Marina (1) } \\
\text { - Invitación } \\
\text { Comandantes en Jefe } \\
\text { (16) }\end{array}$ \\
\hline
\end{tabular}

Fuente: Elaborado a partir de la información disponible en www.camara.cl

En cuanto a la categoría "fiscalización", la Comisión realizó múltiples acciones tendientes a fiscalizar al sector defensa y las FF.AA. Ello, se materializa a través del envío frecuente de oficios al Ministerio de Defensa, a las respectivas FF.AA., invitaciones a declarar ante la Comisión a diversas autoridades, funcionarios o asesores competentes sobre materias conocidas por la Comisión. Los intercambios con la sociedad civil son otro campo de acción de la Comisión. Esto último se materializa a través de la figura de las Jornadas Temáticas, las Audiencias Públicas e invitaciones a centros de estudios o think tanks para que manifiesten su opinión ante la Comisión o presenten información relevante relativa a proyectos de ley vistos por esta o bien para intercambiar opiniones y visiones sobre aspectos relativos al sector defensa que puedan ser de interés para la denominada "comunidad de defensa". Una última categoría relevante en la que es posible agrupar el trabajo de la Comisión, corresponde a las relaciones civil-militares, traducida en invitaciones a autoridades 
del sector defensa, jefes castrenses y otros actores. Ello, con el objeto de intercambiar pareceres y opiniones sobre hechos ocurridos o bien sobre materias legislativas tramitadas en la comisión.

\section{Conclusiones}

Las comisiones de defensa de ambas cámaras no solo proponen a la sala la aprobación o rechazo de los proyectos de ley que se someten a su conocimiento en general y en particular, la aprobación presupuestaria anual en las partidas de defensa, la entrada de tropas extranjeras al territorio o la salida de tropas nacionales e incluso la declaración de estado de asamblea en caso de guerra. Como se pretende desarroIlar en la investigación, las comisiones de defensa nacional juegan un papel clave en la fiscalización de los procesos administrativos y el devenir de cada una de las reparticiones del Ministerio de la Defensa Nacional, como asimismo de cada uno de los servicios que componen las Fuerzas Armadas y de Orden en el caso de la Cámara de Diputados y en la formulación de las políticas de defensa.

\section{Referencias}

Aleman, Eduardo; Pachon, Mónica. 2008. "Las Comisiones de conciliación en los procesos legislativos en Chile y Colombia". Política y Gobierno XV(1): 3-37.

Aninat, Cristóbal; Londregan, John; Navia, Patricio; Vial, Joaquín. 2006. "Political institutions, policymaking processes and policy outcomes in Chile". Research Network Working Paper R- 521, IADB, Latin American Research Network.

Aninat, Cristóbal. 2004. "Balance de poderes legislativos en Chile: ¿Presidencialismo exagerado o base de un sistema político cooperativo?" Política 47 (2): 127-148.

Berríos, Fabiola; Gamboa, Ricardo. 2006. "El Congreso Nacional chileno y el ejercicio de sus funciones legislativa y fiscalizadora". Política 47 (2): 99-126.

BeJAR, LUIS. 2007. "La representación parlamentaria en América Latina: las comisiones permanentes y los partidos en el Congreso". América Latina Hoy 43: 107-122.

Boeninger, Edgardo. 2007. Políticas Públicas en Democracia. Institucionalidad y experiencia chilena. Uqbar Editores: Santiago.

BORN, HANs. 2002. "Learning for best practices of parliamentary oversight of the security sector", Working Paper No 1, Geneva, Center of Democratic Control of Armed Forces.

Born, Hans; Flury, P.; LunN, Simon. 2003. Oversight and Guidance: the relevance of parliamentary oversight of security sector and its reform. DCAF Document 4, Brusselas, Geneva. 
Bruneau, Thomas. 2005. "Civil-Military Relations in Latin America: The Hedgehog and the Fox Revisited". Fuerzas Armadas y Sociedad 19 (1): 111-131.

Bruneau, Thomas; Matel, Fiorina. 2008. "Towards a new conceptualisation of democratization and Civil- Military relations". Democratization 15 (5): 909-927.

Bruneau, Thomas; Matel, Cristiana; Sakoda, Sak. 2009. "National Security Councils: their potential functions in democratic civil- military relations". Defense and Security Analysis 25 (3): 255- 269.

Carey, John. 2002. "Parties, coalition and the chilean Congress in the 1990s". En Morgenstern, S.; Nacif, B. (editores): Legislative Politics in Latin America. Cambridge University Press: 222-253.

Celi, Pablo. 2003. Nuevas tendencias en seguridad y defensa en América Latina. Atlas Comparativo de la Defensa en América Latina. Resdal, Buenos Aires, Argentina.

Cox, Gary; Morgenstern, Scott. 2002. "Epilogue: Latin America reactive assamblies and proactive Presidents". En Morgenstern, S.; Nacif, B. (editores): Legislative Politics in Latin America. Cambridge University Press: 446-468.

García, Mercedes; Sanchez, Francisco. 2002. "Las comisiones legislativas en América Latina: una clasificación institucional y empírica". WP 212, Institut de Ciencies Politiques i Socials, Barcelona.

Ferraro, Agustín. 2008. "Friends in High Places: Congressional Influence on the Bureaucracy in Chile". Latin American Politics and Society 50 (2): 102-129.

Follietti, Gilda; Tibiletti, Paz. 2004. Parlamento y defensa en América Latina: El papel de las comisiones. Vol. I: Argentina, Brasil, Chile y Uruguay. Resdal, Buenos Aires, Argentina.

Fuentes, Claudio. 2008. "Construyendo supremacía civil: el difícil test del control civil sobre las Fuerzas Armadas en el Cono Sur". Documento de Trabajo, CLACSO. www.bibliotecavirtualclacso.org.ar

Huneeus, Carlos; Berríos, Fabiola. 2004. "El Congreso Nacional en un régimen presidencial. El caso de Chile". Revista de Derecho Público 66: 61-95.

KIngdon, J. 1995. Agendas, alternatives and public policies. Addison Wesley: NY.

Lahera, Eugenio. 2002. Introducción a las Políticas Públicas. Fondo de Cultura Económica, México D.F.

Libro de la Defensa Nacional de Chile. 2010. Ministerio de Defensa Nacional.

Morgenstern, Scott. 2002. "Explaining Legisltive Politics in Latin America". En Morgenstern, S.; Nacif, B. (editores): Legislative Politics in Latin America. Cambridge University Press: 413-445.

Payne, J. Mark; Zovatto, Daniel; Carrillo, Fernando; Allamand, Andrés. 2003. La política importa. Democracia y desarrollo en América Latina. Washington D.C: BID. 
EL ROL DE LA COMISIÓN DE DEFENSA DE LA CÁMARA DE DIPUTADOS EN LA FORMULACIÓN...

Peters, Guy. 2003. "La capacidad para gobernar; ¿Retrocediendo hacia el centro?" Revista del CLAD 27: Caracas: 7-28.

Pion-Berlin, David; Trinkunas, Harold. 2001. "Attention Deficits: Why Politicians Ignore Defense Policy in Latin America", Latin American Research Review 42.3, 2007.

Polloni, Marco; Contreras, Arturo; Ortiz, Claudio. 2001. "Relaciones entre las Fuerzas Armadas y el Poder Legislativo en Chile: Análisis y proposiciones". Security and Defense Studies Review, Vol. 1, № 1, Spring 2001.

RiaL, JUAN. 2004. Los cambios relacionados con el Estado Nación y su influencia sobre las Fuerzas Armadas. Simposio Defensa, Sociedad y Desarrollo. Buenos Aires, Argentina.

Rivera, José Antonio. 1998. "Las comisiones en las legislatures: su papel en las políticas públicas". Política y Gobierno 5 (2): 522-556.

Red Resdal. Parlamento y Defensa en América Latina: el Papel de las Comisiones. National Democracy Endowment, Buenos Aires, Argentina.

Schmidt Hebbel, Klaus. 2007. "Chile's Growth and development: Leadership, Policy Making Process, Policies, and Results". Paper preparado for The Comission on Growth and Development. Disponible en www.iadb.org

Siavelis, Peter. 2001. "Chile: las relaciones entre el poder ejecutivo y el poder legislativo después de Pinochet". En Lanzaro, J. (ed.) Tipos de Presidencialismo y coaliciones políticas en América Latina, CLACSO: Buenos Aires.

Siavelis, 2002. "Exaggerated Presidentialism and moderate Presidents: executive-legislative relations in Chile". En Morgenstern, S.; Nacif, B. (editores): Legislative Politics in Latin America. Cambridge University Press: 79-113.

Stein, Ernesto; Tommasi, Mariano. 2006. "La Política de las Políticas Públicas". Política y Gobierno 13 (2): 393-416.

Stein, Ernesto (editor). 2006. La Política de las Políticas Públicas: Progreso Económico y Social en América Latina. BID: Washington.

USAID. 2005. Handbook of Legislative Strengthening. Center for Democracy and Governance, Washington DC.

Van Eekelen, Willem F. 2005. The Parliamentary Dimension of Defence Procurement: Requirements, Production, Cooperation and Acquisition; Geneva Centre for the Democratic Control of Armed Forces Occasional Paper-5.

Veloso, David. 2004. Chile: Evaluación del Funcionamiento de la Comisión de Defensa del Parlamento. Parlamento y defensa en América Latina: El papel de las Comisiones. Vol. I: Argentina, Brasil, Chile y Uruguay. Red Resdal, Buenos Aires, Argentina. 
Valdivieso, Patricio. 2009. "Congreso Nacional y política exterior chilena: estado actual y algunas propuestas". Estudios Internacionales 148: 147-176.

Weeks, Gregory. 2006. "Inching Toward Democracy: President Lagos and the Chilean Armed Forces", In Silvia Borzutzky and Lois Hecht Oppenheim (eds.). After Pinochet: The Chilean Road to Democracy and the Market, Gainesville: University Press of Florida: 26-41.

Weyland, Kurt. 2002. "Limitations of rational choice institutionalism for the study of Latin American Politics". Studies in Comparative International Development 37 (1): 57-85. 


\section{ARTÍCULOS CIENTÍFICOS}





\title{
ALUMNOS MEDIADORES. CONSTRUYENDO LA PAZ
}

\author{
STUDENT MEDIATION. MAKING PEACE
}

Rosaura Paulero*

Fecha de recepción: 6 mayo 2011.

Fecha de aceptación: 17 mayo 2011.

\begin{abstract}
Resumen
El presente artículo es producto de más de una década de trabajo en escuelas públicas, implementando programas de alumnos mediadores. Estos intervienen en conflictos entre sus pares. A largo de todo el trabajo desarrollado se han formados más de 2.600 alumnos mediadores y capacitados más de 5.000 docentes. Las conclusiones que se presentan son el resultado de la recolección de testimonios e informes de los involucrados (alumnos, familias, docentes y directivos), y como consecuencia de esta experiencia es que podemos postular el carácter formativo y preventivo de la inclusión de la mediación en la escuela.
\end{abstract}

Palabras clave: alumnos mediadores, prevención, resolución.

\begin{abstract}
This article is the product of more than 10 years of work in public schools, using programs of students mediation. They take part in conflicts between them. Along all this work we have formed more than 2.600 students mediators and have receiving the knoweldge more than 5000 teachers. This conclusions are the result of the compilation of testimonies and reports of the envolved ones (students, familias, teachers and executives) and like a result of this experinece it is we can postulate the educative and preventive carachter to implemate the mediation in the school.
\end{abstract}

Key words: student mediation. prevention. resolution.

Licenciada en Psicología. Mediadora. Coordinadora equipos de mediadores escolares. Ministerio de Educación. Gobierno de la ciudad autónoma de Buenos Aires, Argentina.

Correo:rpaulero@ciudad.com.ar 


\section{El campo de trabajo}

Se dice que el conflicto es un rasgo inevitable de las relaciones sociales. El problema radica en que todo conflicto puede adoptar un curso constructivo o destructivo. Por lo tanto la cuestión no es eliminar el conflicto, sino asumirlo y enfrentarlo con recursos que nos permitan salir enriquecidos de esa situación.

El conflicto tiene muchas funciones y valores positivos. Evita el estancamiento, promueve el interés y la curiosidad, es la raíz del cambio personal y social, por consiguiente, ayuda a construir identidades, a conocernos mejor y a conocer a los demás.

La escuela, como espacio de encuentro de diferentes actores con multiplicidad de intereses y con diversidades culturales, sociales e individuales es generadora de diferencias y conflictos.

La intolerancia, la discriminación, las dificultades de comunicación se trasladan al aula y a la escuela. La crisis social y familiar hace que la escuela asuma funciones que históricamente no le estaban asignadas.

Partimos de considerar nuestro trabajo desde lo que se denomina metodológicamente investigación-acción. Lo fundamental se basa en la reflexión y comprensión sistemática de la práctica a efectos de mejorarla y transformarla. José Contreras Domingo sintetiza este proceso como "acción-observación-reflexión-nueva acción, etc.", por ello hay que entender el proceso de investigación-acción como un ciclo, un "bucle recursivo" ${ }^{\prime \prime}$.

\section{¿Por qué la mediación?}

La mediación es un proceso de comunicación por medio del cual un tercero imparcial, Ilamado mediador, ayuda a los participantes de un conflicto a dialogar sobre sus distintas perspectivas, explorar las emociones involucradas, reconocer sus intereses y necesidades y facilita la búsqueda de soluciones mutuamente satisfactorias.

Las características de la mediación son la voluntariedad, confidencialidad, imparcialidad, flexibilidad y autocomposición de las partes.

La mediación, como método de resolución de conflictos, ayuda a los miembros de la comunidad educativa a analizar y resolver sus conflictos desde perspectivas

Contreras, D. (1994) "Tema del mes: la investigación en la acción". España. Cuadernos de Pedagogía N2 224. 
cooperativas y positivas, atentas y respetuosas con los sentimientos e intereses de todos los involucrados.

Es por ello que en el año 1997 acepté la invitación para integrar un equipo interdisciplinario que se proponía realizar la primera experiencia local de Mediación Escolar, Ilevada adelante por un área del gobierno. Teníamos un esquema básico de trabajo. Nos planteábamos el carácter piloto de nuestra labor. Aún hoy, después más de 10 años de trabajo ininterrumpidos, seguimos conservando y reivindicamos el trabajo como artesanal. El equipo tiene como función capacitar y acompañar a la institución educativa que decida implementar un Programa de Alumnos Mediadores, trabajando como equipo externo a la institución educativa. La frecuencia de concurrencia a la escuela varía de acuerdo a la etapa del programa.

\section{Programa de alumnos mediadores}

Cuando comenzamos a trabajar implementando programas de alumnos mediadores en escuelas primarias y secundarias, nos basamos en experiencias de otras partes del mundo y en nuestra propia experiencia como mediadores.

Planteamos como objetivos de la inclusión de la mediación en el sistema educativo:

- $\quad$ Reconocer las capacidades para tratar los conflictos constructivamente.

- Adquirir habilidades comunicacionales y de negociación para facilitar la escucha respetuosa, el reconocimiento de la perspectiva del otro, el protagonismo y la creatividad en el abordaje constructivo de los conflictos.

- Promover la resolución de conflictos a través de métodos no adversariales y la disminución de los niveles de violencia, fortalecer los valores democráticos y de participación y mejorar la convivencia cotidiana.

\section{Definición y características}

Los programas de alumnos mediadores persiguen la creación de un equipo de mediadores integrado por alumnas y alumnos que son preparados para intervenir en conflictos entre sus pares.

Los alumnos son capacitados en abordaje colaborativo de conflictos y algunos de ellos son entrenados en mediación. Trabajan en comediación, de modo que las mediaciones son conducidas por un equipo.

Los programas de alumnos mediadores no sustituyen las sanciones establecidas frente a situaciones de indisciplina, sino que pueden complementarse con ellas. Si en 
el desarrollo de un conflicto interpersonal se producen faltas, deben ser sancionadas. Pero esta sanción no solucionará el problema, por lo tanto, es posible su derivación a mediación.

El fundamento de la mediación entre pares se basa en diferentes aspectos.

La mediación es un procedimiento jerárquico, los mediadores no ejercen poder sobre las partes ya que no deciden cómo termina el conflicto, sino que son los involucrados los que sí lo hacen. Por lo tanto, ambas partes deben hacerse responsables de la solución y por consecuencias del conflicto. Todo este proceso se facilita al ser el mediador un par, al manejar los mismos códigos comunicacionales y al estar seguras las partes que los mediadores no podrán ejercer poder sobre ellos. Esta creencia sería muy difícil de sostener si los mediadores fueran otros adultos de la institución escolar, dada su estructura piramidal. Asimismo, contribuye a desalentar la actitud paternalista de recurrir a un tercero adulto para que resuelva el conflicto.

El rol del docente, directivo o preceptor en la institución escolar hace necesario que el adulto se sienta impelido de dar una respuesta, una opinión, una solución, y así deben hacerlo en muchas situaciones. En cambio, los alumnos mediadores no sienten la misma presión, lo que les permite generar y sostener la tensión necesaria para que las partes se apropien no solo del conflicto, sino también de la construcción de la solución mutuamente satisfactoria que habrá de ponerle fin.

Finalmente, el principio de confidencialidad del proceso permite que el intercambio que se produce entre las partes sea sincero ya que nadie "deberá mentir" o "tergiversar las cosas" para ocultar una acción que podría ser vista como "reprochable o censurable" y, por consecuencia, sujeta a posterior sanción, si fuera reconocida en presencia de un adulto.

Desde 1997 se han desarrollado acciones dirigidas a difusión, capacitación, entrenamiento, seguimiento, supervisión y evaluación de la implementación de programas de mediación entre pares, asimismo, a poco de andar la realidad exigió llevar adelante intervenciones que implicaron la conducción de procesos de comunicación y de construcción de acuerdos, incluyendo tanto mediaciones como otros procesos colaborativos: generación de consenso u otros diseños de resolución de problemas.

Luego de más de diez años de trabajo y a pesar de que la situación social se observa día a día más compleja, constatamos que muchos de estos objetivos se han cumplido en las instituciones que han implementado con compromiso y dedicación programas de alumnos mediadores. De esto intentará dar cuenta el presente artículo.

Plantearé el marco normativo de la educación para la paz y la resolución cooperativa de conflicto, el marco pedagógico que sostiene el trabajo de campo, el modo particular de implementación de programas de alumnos mediadores y los resultados obtenidos. 


\section{Marco normativo}

El contenido de Educación para la Paz aparece planteado en el espíritu y la letra de la Ley Nacional de Educación ( $n^{\circ} 26.206$ ).

ARTÍCULO $8^{\circ}$ - La educación brindará las oportunidades necesarias para desarrollar y fortalecer la formación integral de las personas a lo largo de toda la vida y promover en cada educando/a la capacidad de definir su proyecto de vida, basado en los valores de libertad, paz, solidaridad, igualdad, respeto a la diversidad, justicia, responsabilidad y bien común.

ARTÍCULO $11^{\circ}$ - c) Brindar una formación ciudadana comprometida con los valores éticos y democráticos de participación, libertad, solidaridad, resolución pacífica de conflictos, respeto a los derechos humanos, responsabilidad, honestidad, valoración y preservación del patrimonio natural y cultural.

ARTÍCULO $123^{\circ}$ - j) Desarrollar prácticas de mediación que contribuyan a la resolución pacífica de conflictos.

En un nivel más concreto se plasmaron los contenidos básicos comunes para el área de la Formación Ética y Ciudadana, acordados en el Consejo Federal de Educación. Dicha área cuenta con 5 ejes de formación:

- Persona

- Valores

- Normas sociales

- Procedimientos

- $\quad$ Actitudes generales

En cualquiera de estos ejes se encuentran contenidos relacionados con la Educación para la Paz.

Avanzando en el nivel de concreción encontramos que en los diseños curriculares correspondientes a los diferentes niveles se da lugar al trabajo con los valores de paz, solidaridad, justicia. Desde una apreciación general, como las planteadas en el marco general del nivel inicial, hasta la implementación institucional de programas de métodos pacíficos de resolución de conflictos como la mediación escolar, la escuela "se hace cargo" de este contenido necesario para la adquisición de habilidades sociales que favorezcan la convivencia armoniosa y pacífica.

A partir del segundo ciclo de la escuela primaria, los contenidos trabajados en Educación para la Paz se plantean como contenidos transversales, ya que brindan al alumno/a habilidades, conocimientos y actitudes que le serán de utilidad en su vida 
cotidiana escolar. Coincido con Zulema P. de Meaños ${ }^{2}$ en que "... la formación integral encuentra en esta propuesta de transversalidad de contenidos una solución que, por otra parte, puede aportar mucho a nuestra práctica educativa en cuanto a organización y globalización de contenidos y estrategias interdisciplinarias...".

\section{Inserción en la planificación escolar}

La transversalidad de los contenidos ofrece una solución metodológica que puede en algunos momentos parecer una dificultad. Si dichos contenidos no están en ninguna "materia", entonces no están en ningún lado. O, por el contrario, si están en todos lados, ya que aparecen en cada acción, no encuentran un momento específico para su tratamiento. Para evitar esta dispersión, Siede ${ }^{3}$ menciona cinco formatos diferentes y convergentes de incorporación a los procesos didácticos:

- Abordaje formativo de situaciones cotidianas: tomando hechos de la convivencia escolar y formulándolos como problemas, transformándolos en herramientas pedagógicas. En esta transformación es donde interviene el docente.

- Momento de enseñanza dentro de otras áreas: algunos contenidos de otras áreas, como, por ejemplo, las guerras en el área de Sociales, permiten la inserción de contenidos de FEyC.

- $\quad$ Proyectos específicos: son temas que requieren o justifican por la realidad social de la comunidad educativa un tratamiento especial. En esos casos se trabajan otorgándoles una carga horaria específica, en general involucran a más de un grupo-clase dentro de la escuela.

- Área de Conocimiento del Mundo, Primer Ciclo EGB: FEyC comparte el área con Sociales, Naturales y Tecnología.

- $\quad$ Aérea con carga horaria propia en el Tercer Ciclo EGB.

La Educación para la Paz encuentra cabida en cualquiera de las modalidades mencionadas. Considero que la implementación de un Programa de Mediación Escolar se encuentra en la tercera propuesta como proyecto específico.

De Meaños, Z. Los Contenidos Transversales, El Ateneo, 3ª ed. Bs. As.; 1999.

Siede, I. "Formación ética y ciudadana". Orientación general y proyecto formativo del área. Documentos. GCABA. 


\section{Elaboración de un proyecto}

Entendemos los proyectos transversales de Educación para la Paz como "un conjunto de actividades de enseñanza que buscan atender necesidades formativas de los estudiantes en el ámbito de prácticas actuales de la ciudadanía que demandan una respuesta de la escuela" ${ }^{4}$.

Entre sus propósitos se encuentran:

- Enseñar saberes, prácticas reflexivas y hábitos de vida que constituyan las bases para que los niños y niñas puedan integrarse a la sociedad, desde sus propios intereses y proyectos, para contribuir a mejorarla.

- $\quad$ Establecer modos institucionales de convivencia democrática que favorezcan la enseñanza de formas justas y solidarias de ejercicio del poder.

- Fomentar actitudes y hábitos de cuidado y defensa de la dignidad personal, de solidaridad y compromiso con los otros, de justicia en la resolución de conflictos y cooperación en proyectos comunes, de autonomía en la toma de decisiones y en la elección de modos de vida.

- El desafío: ¿Cómo pasar de la enseñanza de valores por sus meros enunciados a una enseñanza en valores?

- Los mediadores sabemos que la mediación nos plantea el desafío de trabajar con valores como la solidaridad, responsabilidad, compromiso, participación y el respeto. La mediación insta al ejercicio cotidiano de la cooperación y reconoce la interdependencia que existe entre los seres humanos.

- $\quad$ Recordemos que J. Piaget ${ }^{5}$ plantea que dado que la cooperación es un método, es difícil ver cómo podría cobrar existencia si no fuera mediante su propio ejercicio.

\section{Marco pedagógico}

Paulo Freire ${ }^{6}$ dice que la educación o bien hace un esfuerzo por domesticar a los estudiantes en conformidad a los valores y normas del grupo que manda o, bien para motivar a sus estudiantes para que sean creativos, responsables y libres. Siguiendo esta línea es que podemos plantear dos modelos de educación. Juan Pablo Lederach

4 Documento de Formación Etica y Ciudadana, Secretaría de Educación, Gobierno de la Ciudad de Buenos Aires.

5 Piaget, J. (1932), El Criterio Moral en el niño.

6 Citado por Lederach, J. y Chupp, M. (1995), ¿Conflicto y Violencia? Busquemos Alternativas Creativas Akron, PA. 
y Marcos Chupp, en Conflicto y Violencia...7, afirman que el modelo de educación transformadora debería orientarnos en nuestro trabajo en resolución de conflictos.

Para Freire, en la educación tradicional el sistema educativo se basa en un modelo parecido al bancario. Se percibe a los maestros como a los poderosos que poseen la información esencial. Los estudiantes, en cambio, son recipientes vacíos. El maestro consigna la información en los estudiantes para sacarla después del examen. Así que lo más importante es poner todo en la memoria, aunque el alumno no sepa cómo poder usarlo en su vida.

La educación transformadora se plantea que se puede aprender lo que llena una necesidad personal, también se puede aprender haciendo y en un contexto determinado que genere confianza.

El objetivo es crear una experiencia educativa, basada en problemas reales, con gente, un grupo que genere confianza, probando diferentes alternativas.

Los participantes de un sistema transformativo, son vistos como personas creativas, inteligentes y con la capacidad de actuar. La educación transformadora hace uso de muchas dinámicas, ejercicios, casos, juegos y experiencias a través de los cuales es posible crear un ambiente distinto, que permita una vivencia. Si uno se involucra en un proceso transformativo sobre la violencia y el conflicto, se tendrá que abandonar la concepción bancaria y tradicional de la educación que exige un papel pasivo a los alumnos.

\section{Etapas de un programa de mediación entre pares}

\section{Contacto inicial}

La implementación del trabajo en la escuela da comienzo con una etapa introductoria en la que se explora el interés de la comunidad educativa en el programa así como el compromiso de las autoridades.

El primer contacto institucional, a cargo de las coordinadoras, tiene como objetivo explicar las características del programa y los compromisos institucionales que se requieren para abordar la intervención. Asimismo, se explora el interés del equipo de conducción en el programa y su compromiso.

\section{Sensibilización}

El siguiente momento tienen como objetivo explicar el programa a docentes, administrativos y preceptores y evaluar, el apoyo e interés de los mismos.

Lederach, J y Chupp, M. (1995), ¿Conflicto y Violencia? Busquemos Alternativas Creativas Akron, PA. 
Esta actividad se desarrolla en una jornada de sensibilización organizada al efecto.

El requisito que tiene el equipo para desarrollar el programa es obtener un apoyo mayor al $80 \%$ de los participantes (los asistentes deben completar una encuesta anónima).

\section{Consolidación}

Una vez que el equipo decide implementar el programa en la institución, da comienzo a la etapa de gestación del proyecto.

El objetivo de esta etapa es construir con la comunidad educativa un programa a la medida de sus necesidades, respetando ciertas pautas básicas.

Las acciones que se desarrollan varían según las posibilidades de cada escuela, incluye una aproximación a la dinámica institucional mediante entrevistas y/o espacios compartidos por todos los miembros de la comunidad con el fin de integrar visiones, desafíos y propuestas así como generar compromiso con el programa.

\section{Capacitación}

El siguiente momento está centrado en la capacitación de los distintos integrantes de la escuela.

\section{A docentes, preceptores y directivos}

Se propone una capacitación de adultos de la comunidad en un curso introductorio en Resolución de Conflictos - Mediación que aborda la temática del conflicto, la comunicación, la negociación colaborativa y la mediación.

Los objetivos de dicha capacitación son:

* Favorecer la participación y el compromiso de los miembros de la comunidad educativa en el programa.

* Identificar el conflicto como un componente más de nuestras vidas reconociendo su valor positivo. Analizar distintos tipos de conflictos. Reconocer las capacidades para tratar los conflictos constructivamente.

* Adquisición de habilidades comunicacionales y en negociación colaborativa para: facilitar la escucha mutuamente respetuosa, el reconocimiento de la perspectiva del otro, el protagonismo y la creatividad en un abordaje constructivo de los conflictos.

* Formar a los docentes como capacitadores de alumnos, transformándolos en multiplicadores de la experiencia, favoreciendo así la apropiación del programa y el desarrollo del mismo en forma autogestora. 
Una vez finalizada esta etapa de capacitación de docentes, preceptores, directivos, etc., se vuelve sobre el diseño del programa con la finalidad de ajustarlo a la próxima etapa de acuerdo con el nuevo contexto generado tras la capacitación de adultos.

\section{Taller de padres}

Durante este etapa se abordan también talleres de padres en los que se les informa sobre el programa y se los introduce en temas como conflicto y comunicación. La participación en estos talleres depende de las características de la institución, nivel de enseñanza y difiere según las peculiaridades de cada "grupo padres".

\section{A alumnos}

En la capacitación introductoria de alumnos participa todo el curso, está a cargo de uno a más docentes de ese curso. Tiene una duración que varía según las características de la escuela y de cada grupo áulico e incluye temas similares a la capacitación brindada a los docentes. La metodología utilizada se basa en dinámicas que incluyen actividades lúdicas, ejercicios prácticos, juegos de rol, etc.

Los objetivos son: promover la reflexión y revisión de actitudes, la adquisición de nuevas habilidades con el propósito de mejorar la comunicación y prevenir situaciones de violencia, mejorando la convivencia cotidiana no solo en la escuela, sino en todos los ámbitos presentes y futuros.

Durante la capacitación de alumnos se brinda un espacio de tutoría a los docentes en la que el equipo externo funciona como apoyo con el objetivo de evacuar dudas y ayudar en el diseño y/o modificación de las actividades previstas.

\section{Selección de mediadores}

Al finalizar la capacitación introductoria, se lleva a cabo la selección de alumnos mediadores, la metodología de selección varía también de acuerdo a cada experiencia, sin embargo, todos incluyen la autopropuesta de los interesados, la exploración de la opinión de los compañeros y el aval de docentes y directivos.

\section{Entrenamiento}

Finalmente la etapa de capacitación finaliza con el entrenamiento de alumnos mediadores. La duración de los entrenamientos varían de acuerdo a las posibilidades de cada institución y el nivel de la misma, en general el equipo recomienda utilizar alrededor de 10 horas reloj para el nivel primario y 16 horas reloj para el nivel secundario.

Este entrenamiento lo imparte el equipo externo junto con algún docente de la escuela, que asesora a la institución. 
Se incluye entre sus contenidos: las características de la mediación, el rol del mediador, las reglas del proceso y se los prepara para el manejo de este: creación de contexto, exploración de perspectivas, emociones, intereses y necesidades, generación de opciones, selección de soluciones y construcción de acuerdos. El entrenamiento se basa en dinámicas participativas y juegos de rol.

\section{Puesta en marcha del centro de mediación}

Esta etapa comienza con la graduación de los alumnos mediadores en un acto del que participa toda la comunidad educativa con el objetivo de dar a conocer la puesta en marcha del centro de mediación y de legitimar el rol de los mediadores.

El centro se organiza con parejas de comediadores ya que los alumnos mediadores siempre trabajan de a dos, horarios, turnos, espacios, temas que se incluyen o excluyen, modalidades de referencia de mediaciones, etc.

Durante esta etapa también se encaran acciones dirigidas a la publicidad y difusión del servicio de mediación entre pares.

\section{Seguimiento y supervisión}

El seguimiento y supervisión de los alumnos mediadores se realiza en un primer momento en reuniones semanales que complementan la capacitación.

Al finalizar la mediación, los mediadores alumnos completan un formulario que se utiliza con fines estadísticos.

Se realizan reuniones en donde se trabajan las dificultades del rol y las de la implementación. Estas reuniones no se hacen exclusivamente con alumnos mediadores, sino también con docentes y directivos. Las mediaciones escolares asimismo se rigen por el principio de confidencialidad, por ende, el proceso no se realiza ante la presencia de adultos, ni con posterior información sobre el contenido del caso a estos. Sin embargo, esto no implica que no exista un monitoreo sobre la práctica de los mediadores, ya que cuentan con un espacio de supervisión a cargo de un adulto especialmente preparado para tal función.

Finalmente esta etapa puede incluir distintos momentos (por lo general una vez al año) donde se profundiza la capacitación de los mediadores

\section{Evaluación de la experiencia}

Durante el proceso de implementación se desarrollan distintos tipos de evaluación de las etapas (cuestionarios, encuestas, informes estadísticos de las mediaciones, etc.). Sobre el final de la intervención del equipo externo se realiza una evaluación del programa que incluye instrumentos como entrevistas con los distintos actores de la comunidad educativa, cuestionarios autoadministrados, evaluaciones estadísticas. 


\section{Resultados cuantitativos}

Cantidad de capacitados a diciembre de 2008.

- $\quad$ Alumnos mediadores: 2.611

- Alumnos capacitados en resolución de conflictos: 20.292

- Docentes, preceptores y directivos: 5.185

- $\quad$ Talleres con padres: 540

Los informes de mediaciones presentados por los alumnos mediadores.

\section{Conclusiones}

- Se destacan como principales motivos de mediación los insultos $(20,6 \%)$, las burlas $(16,6 \%)$ y los malentendidos $(15,4 \%)$.

- $\quad$ El $65 \%$ de los participantes en las mediaciones eran mujeres.

- $\quad$ En el $46 \%$ de los casos, los participantes de las mediaciones no mantuvieron una charla previa a la misma.

- Como motivos para solicitar la mediación se destacan la necesidad de amigarse de las partes (32\%) y el consejo de un docente $(26 \%)$.

- $\quad$ El 85\% de las mediaciones se resolvió con acuerdo.

- Según los mediadores, la mediación resultó muy satisfactoria o satisfactoria para los participantes en el $82,1 \%$ de los casos.

\section{Resultados cualitativos}

Las conclusiones que se presentan a continuación son resultado de la recolección de testimonios e informes de los involucrados (alumnos, familias, docentes y directivos).

Como resultado de esta experiencia es que podemos postular el carácter formativo y preventivo de la inclusión de la mediación en la escuela.

Teniendo en cuenta las características de imparcialidad, voluntariedad y protagonismo de las partes no podemos pensar que el mediador "enseña", no lo hace de manera directa pero sí en forma secundaria.

La implementación de programas de resolución de conflictos y mediación entre pares posee carácter formativo ya que los resultados observados en las distintas experiencias tienen características de aprendizaje:

- $\quad$ No son imputables a procesos madurativos.

- Son duraderos y modifican las estructuras de los participantes.

- Preparan dichas estructuras para nuevas adquisiciones. 
- $\quad$ El relevamiento de la experiencia nos aporta múltiples situaciones o anécdotas donde se reflejan estos enunciados teóricos.

- $\quad$ Podemos identificar cuatro sujetos de cambio o aprendizaje.

1. Los alumnos mediadores

2. Los alumnos que son parte de mediaciones

3. Los alumnos que reciben capacitación en resolución de conflictos

4. La institución escolar-incluyendo a los adultos-

1. Los cambios más notorios se observan en los alumnos mediadores. Adquieren habilidades para el reconocimiento y manejo de conflictos, la comunicación y la conducción de procesos, a la vez que ayuda a desarrollar su empatía y a poner en acción sus aprendizajes. Todo ello les permite mejorar su capacidad de expresarse verbalmente, ser más tolerantes y flexibles. Aceptan más fácilmente el punto de vista del otro.

La formación y el rol favorece su autoestima: se sienten útiles. Por lo tanto, promueve el compromiso y la participación. Esto implica que en la institución participan en muchas otras actividades.

Permite que reconozcan mejor sus emociones.

Algunos chicos que eran muy tímidos pudieron integrarse mejor al grupo.

Algunos de los llamados líderes negativos pudieron encontrar un rol positivo.

Por ejemplo, una docente nos comentó que al salir de la escuela, se encontró en una plaza cercana a dos alumnos que eran eternos rivales que estaban compartiendo amablemente un juego. Uno de ellos era mediador. Luego, al conversar con él, manifestó que se daba cuenta que era más tolerante y que ahora podía compartir espacios con algunos chicos que no eran sus amigos y con los cuales quizás no tenía mucho en común.

En los monoblocks de Villa Lugano, un barrio carenciado del sur de la ciudad, los chicos se agrupan de acuerdo a las filas de las torres de edificios, A, B, C, etc. En una escuela media vespertina había un centro de alumnos mediadores, ellos nos comentaron como cosa muy natural que los enfrentamientos entre filas o bandas de filas eran muy frecuentes y violentos. Como en varias filas había chicos mediadores, ellos actuaban como negociadores para evitar esos enfrentamientos.

De parte de las familias también hemos recibido comentarios al respecto. Algunos padres observan que sus hijos a partir de ser mediadores pueden ser más tolerantes con hermanos menores o establecer espacios de comunicación diferentes. Una mamá nos dijo que su hijo (alumno mediador) le dijo: "Mamá, quiero hablar con vos, 
si ahora no me podés escuchar, está bien, pero avísame cuándo vas a poder, porque necesito hablar con vos".

2. Pero también se observan cambios en los alumnos que participan de mediaciones. Participar del proceso les permite: experimentar una manera respetuosa de hablar y ser escuchado, de expresar necesidades y sentimientos. Incrementando la capacidad para reconocer al otro. Pueden encontrar un espacio donde el pensamiento crítico y la toma de decisiones son necesarios y valorados. Aceptar la responsabilidad de sus acciones y recurrir a la creatividad para pensar nuevas maneras de convivencia.

En una escuela primaria un alumno asistía como parte a mediación en forma recurrente. Los alumnos mediadores lo habían apodado el VIP (very important people). En una mediación se trabajó el tema de la amistad y los mediadores realizaron preguntas reflexivas. A partir de allí, su modo de relacionarse cambió y mejoró la convivencia. No asistió más a mediaciones por ese año.

3. Alumnos que reciben capacitación en resolución de conflictos. Por otro lado, relevamos constantemente la opinión de los docentes que refieren que a partir de la introducción de los contenidos de resolución de conflictos, se genera en el aula un mejoramiento del clima, una mejor convivencia. Esto a su vez produce una disposición favorable para la tarea del aprendizaje. Se prioriza el diálogo, por lo tanto disminuyen las situaciones de violencia o agresión.

Un ejemplo es una escuela primaria donde las docentes de $5^{\circ}$ grado habían trabajado con sus alumnos en resolución de conflictos. Históricamente existían discusiones entre los dos grupos de $5^{\circ}$ porque tenían que compartir un patio. Ese año, cuando terminaron el curso de resolución de conflictos, los alumnos se acercaron a sus maestras y les pidieron reunirse todos para acordar un plan para usar el patio. La reunión se realizó con la facilitación de las docentes y el acuerdo al que llegaron lo cumplieron.

En otra escuela los alumnos mediadores hicieron una reunión entre sus compañeros para elegir si usaban buzo o campera de egresado.

4. A nivel institucional, en relación con los adultos, los cambios son más difíciles, si bien no con la misma frecuencia que con los alumnos, también los docentes capacitados refieren cambios personales.

Muchos docentes cuentan que cuando se presentan situaciones en las que se sienten maltratados verbalmente por sus alumnos, pueden actuar distinto. Se toman unos minutos, le proponen al alumno que también se los tome en cuenta, luego conversan y generan un espacio de mayor colaboración.

Directores que plantean que los problemas ya no llegaban a su despacho. 
Docentes que se sorprenden del diálogo que se puede entablar con los alumnos y del poder de reflexión de los chicos.

Se ha observado que la implementación de programas de alumnos mediadores en sus diferentes etapas, generan un mejoramiento del clima institucional. Por ejemplo: en esta institución los docentes se habían capacitado en su totalidad en un curso intensivo durante el receso escolar, y todos de una y otra manera estaban trasladando su capacitación al aula. En aquella reunión los docentes comentaron que el clima escolar se observaba más tranquilo, y el equipo de conducción expresó que tenían la impresión que habían realizado menos llamados al SAME (Servicio de Urgencias Médicas).

\section{Comparativo de la intervención del SAME 1999-2001 (1er. cuatrimestre) en cantidad de intervenciones}

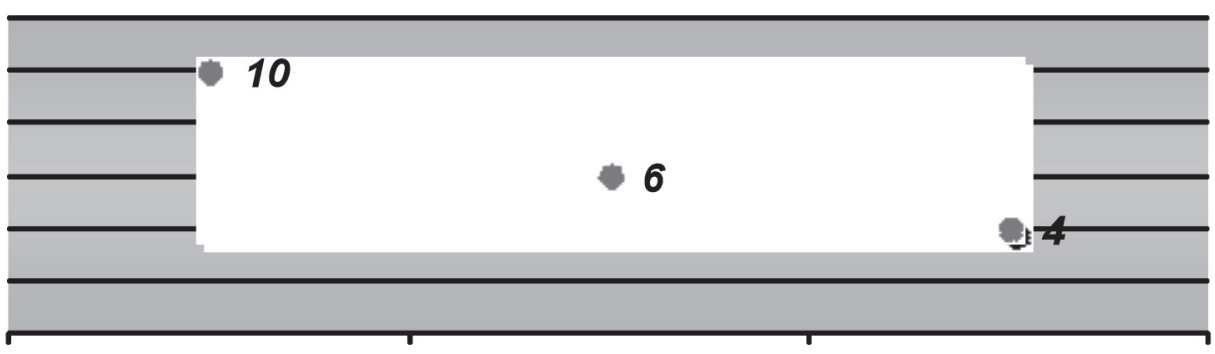

Año 1999

Año 2000

Año 2001

\section{Conclusiones}

Prevenir es llegar antes para que algo no suceda, es evitar, impedir, advertir e informarse. Por ello aprender es prevenir.

De la investigación realizada se concluye que para que estos resultados se den se deberán cumplir con las siguientes características:

- La implementación de un Programa de Alumnos Mediadores debería ser a pedido de la escuela y formar parte del proyecto institucional. Se deberá contar con un consenso o con una mayoría que acepte y promueva el trabajo en el programa. Asimismo, la participación de los alumnos en los espacios de mediación sea como mediadores o partes también tiene que tener como requisito la voluntariedad.

- Para poder implementar este tipo de programas, resulta esencial brindar capacitación a todos los actores institucionales (directivos, docentes, auxiliares, 
alumnos y padres). La formación de docentes como capacitadores de alumnos, con espacios de tutorías, los transforma en multiplicadores de la experiencia y permite el desarrollo desde la autogestión del programa.

- Fuerte compromiso con la tarea de docentes y directivos.

Pero, sobre todo, la mediación escolar constituye un importante trabajo preventivo y formativo, tanto a nivel individual, como colectivo, en tanto permite que los protagonistas de los conflictos tengan la oportunidad de:

- Vivirlo como una oportunidad para examinar diferentes perspectivas.

- Reconocer el impacto de sus respectivas acciones y responsabilizarse por ellas.

- Identificar emociones propias y ajenas.

- Explorar distintos intereses y necesidades.

- Trabajar cooperativamente en la búsqueda de soluciones que sean buena para todos los participantes.

\section{Bibliografía}

Datos estadísticos del Programa de Mediación Comunitaria. Área mediación escolar. GCABA. Argentina.

Girard, K.; KOCH, S. (1998) Resolución de conflicto en las escuelas. España. Granica.

Gotthell, J.; Schiffrin, A. (compiladores) (1996) Mediación: una transformación en la cultura. Buenos Aires. Paidós.

Contreras, D. (1994) "Tema del mes: la investigación en la acción". España. Cuadernos de Pedagogía N2 224.

De Meaños, Z. (1999) Los Contenidos Transversales. El Ateneo, $3^{\text {a }}$ ed. Bs.As.

SIEDE, I. "Formación ética y ciudadana". Orientación general y proyecto formativo del área. Documentos. GCABA

Piaget, J. (1932) El Criterio Moral en el niño.

Lederach, J.; Chupp, M. (1995) ¿Conflicto y Violencia? Busquemos Alternativas Creativas, Akron, PA. 


\section{RECENSIÓN}




\section{NEGOCIACIÓN, MEDIACIÓN Y CONCILIACIÓN, COMO MÉTODOS ALTERNATIVOS DE RESOLUCIÓN DE CONTROVERSIAS}

Núñez Ojeda, Raúl, Ediciones Jurídicas de Santiago, enero de 2009, Santiago de Chile, 220 pp.

Núñez Ojeda es profesor de Derecho Procesal de la Universidad de Chile, Doctor en Derecho, integrante del Foro para la Reforma Procesal Civil del Ministerio de Justicia y de la comisión de estudio sobre sistemas preferentes de solución de conflictos de esta reforma. Su libro expone la investigación desarrollada durante 2005 y 2006 sobre mecanismos no adversariales en los sistemas procesales civiles español, anglosajón, alemán, italiano y francés, a los cuales dedica extensos capítulos, revistiendo particular interés su análisis de la mediación.

Al revisar el sistema procesal español, el autor destaca la aplicación de este método en las comunidades autónomas, como Cataluña y el País Vasco. También, la influencia que han ejercido a favor de esta instituciones de la Unión Europea, como la Recomendación (98) I de la Comisión de Ministros de los Estados miembros sobre la Mediación Familiar. Los fundamentos que arguye son el aumento de litigios familiares y el coste social y económico elevado para los Estados; la necesidad de proteger los intereses del niño y su bienestar, con los problemas que entraña la guarda y el derecho de visitas en supuestos de separación o divorcio; en el desarrollo de vías para reglamentar una solución amistosa de los litigios y en el reconocimiento de la necesidad de reducir los conflictos en interés de todos los miembros, así como en las características de este tipo de litigios. En cuanto a los principios rectores de este mecanismo, enfatiza su necesaria independencia frente a los procesos judiciales.

Respecto al sistema anglosajón, el autor explica que la explosión de los ADR (Alternative Dispute Resolution) se ha debido a tres motivos: el colapso de los órganos jurisdiccionales, por el exceso de causas, el costo y demora que conllevan; el sentimiento de la comunidad de ausencia de mecanismos privados para resolver las controversias; y la incapacidad intrínseca del sistema procesal de garantizar el acceso a la justicia de todos. La mediación se recomienda especialmente cuando entre las partes existe una relación que ha de perdurar en el tiempo, cuando existen delicadas posiciones de reputación, confidencialidad u otras, cuando existen cuestiones técnicas complejas o se requiere premura para resolver la controversia. Existen distintos instrumentos que la contemplan y definen, como el código estadounidense, los estatutos de Florida y la Uniform Mediation Act.

Respecto al sistema civil alemán, el autor señala que si bien Alemania no tiene una cultura de negociación tan marcada como Estados Unidos o Inglaterra, la mediación es una vía recurrente para llegar a acuerdos y que las empresas alemanas han 
incrementado su uso para abordar sus conflictos citando como ejemplo a Siemens y Ericsson que han acudido a la Asociación para la Mediación Comercial y Manejo de Conflictos. Indica que existe una mediación intraprocesal que llevan a cabo los jueces, cuyo límite con la conciliación se hace difuso; y una mediación prejudicial obligatoria para asuntos de baja cuantía (que no excedan de 750 euros). Asimismo, se usan los acuerdos y cláusulas de mediación que se incorporan a los contratos donde las partes acuerdan el procedimiento y ámbito de aplicación de esta instancia. Aclara que si bien el Código Procesal Civil alemán no se refiere específicamente a ella, se le aplican por extensión las reglas del arbitraje. Las materias en que se usa con más frecuencia son separación y divorcio, conflictos medioambientales, de derecho económico, laborales, vecinales, de arrendamiento, de los consumidores y delincuencia juvenil.

Respecto al sistema italiano, Núñez Ojeda indica que la crisis del enjuiciamiento civil ha generado un ambiente propicio para el desarrollo de los mecanismos alternativos al juicio. Leyes de la década del sesenta han regulado la mediación y los artículos 1754 a 1765 y 2950 del Código Civil se refieren a ella. Señala también que en Italia la mediación se equipara a la conciliación.

En cuanto al sistema procesal civil francés, el autor indica que ya un decreto de 1955 instituyó un procedimiento de mediación social, en virtud del cual se requería la intervención del ministro del Trabajo en casos de conflictos laborales sobre remuneraciones, el que fue generalizado por una ley de 1957 y por las Leyes de Auroux en 1982. El Código del Trabajo actual dedica una sección a la mediación y otra al arbitraje y a la conciliación. En materia civil, la mediación fue introducida por una ley de 1995, pero antes la Corte de Casación la había incluido como mecanismo de resolución de conflictos en 1993. Actualmente, en materias civiles se identifica la mediación convencional y la judicial. En esta última, el juez conociendo de un litigio puede proponer a las partes resolver sus diferencias ante un mediador. Así lo contempla el nuevo Código de Procedimiento Civil.

Por último, consideramos especialmente atractivo el capítulo que el autor dedica a exponer sus conclusiones, estadísticas y propuesta normativa. Así, por ejemplo, plantea una serie de cuestiones que pueden suscitarse a partir de la mediación como si la prejudicial ha de ser obligatoria o facultativa, si interrumpe o suspende la prescripción en relación a la demanda judicial posterior, si es el juez quien debe designar al mediador, o las partes, los principios que han de regirla, el deber de confidencialidad del mediador, su rol en materia probatoria, su remuneración y responsabilidad. Desde su perspectiva, la mediación debe ser ágil y desformalizada, pero respetando la garantía constitucional del debido proceso.

Este eminente procesalista se sorprende de que, en breve tiempo, los sistemas procesales civiles de Europa continental hayan comenzado a mirar hacia los sistemas 
procesales anglosajones en la búsqueda de soluciones pragmáticas, eficaces y rápidas para la crisis de la justicia civil, tendencia a la que nuestro país no está ajeno.

Excelente trabajo cuyo mayor aporte, en nuestra opinión, lo constituye esta visión globalizada del apogeo de los mecanismos alternativos al juicio para resolver las controversias, justo cuando se debate su inclusión en la reforma procesal civil de nuestro país, y todavía existe cierto desconocimiento y reticencia acerca de su validez.

Adriana Palavecino 



\section{SOBRE NOSOTROS}

\section{Información básica}

La Revista Chilena de Derecho y Ciencia Política de la Escuela de Derecho de la Universidad Católica de Temuco es una revista de estudios generales de Derecho, Ciencia Política y Resolución Alternativa de Conflictos, que tiene por objeto contribuir al desarrollo de aquellas disciplinas procurando la difusión crítica y plural sobre temas jurídicos y políticos relevantes.

\section{Áreas temáticas}

Ciencias Jurídicas.

Ciencia Política.

Políticas Públicas.

Filosofía Jurídica.

Filosofía Política.

Resolución Alternativa de Conflictos.

\section{Secciones}

Los números de la Revista podrán ser monográficos, siendo una la temática dominante del contenido, o bien, podrán ser misceláneos, siendo variados los contenidos.

La Revista se dividirá en tres secciones permanentes, a las que podrán agregarse otras. Las tres secciones fijas serán la de Derecho, la sección de Ciencia Política y la sección de Resolución Alternativa de Conflictos. También se considerará la inclusión de alguna otra sección complementaria como "Comentarios de Jurisprudencia" y "Recensiones", siempre que se reciban contribuciones originales. 


\section{Procedimiento para la aprobación de artículos}

La Revista Chilena de Derecho y Ciencia Política solo publicará estudios científicos originales que se sometan al sistema de arbitraje.

El procedimiento constará de una etapa previa de evaluación en que el director de la Revista y el Comité Editorial tendrán la facultad de desestimar el arbitraje de los trabajos por no ajustarse a las normas formales, no tener coherencia interna, no poseer una originalidad relevante o por contravenir, total o parcialmente, el espíritu, política editorial, principios e intereses que sostiene la publicación.

En caso de superar la etapa previa, el estudio será sometido a la evaluación de, a lo menos, dos pares. Si ambos aprueban, el artículo se publicará. Si ambos rechazan, o uno aprueba con observaciones y el otro corrector rechaza su publicación, el trabajo será devuelto a su autor. En el supuesto de que ambos pares aprueben con observaciones, o uno apruebe y el otro lo haga indicando observaciones, el original será enviado a su autor para que las considere. Una vez incorporadas, el Comité Editorial estimará la incorporación de las mismas. Finalmente, en el caso de que un árbitro apruebe la publicación y otro la rechace, el Comité Editorial evaluará, conforme a otros méritos, la posibilidad de la inclusión en el número.

\section{Correspondencia}

Toda aquella correspondencia que verse sobre cuestiones académicas o envío de originales deberá enviarse al correo de la Revista: derechoycienciapolitica@uct.cl . En caso de envío postal: Revista de Derecho y Ciencia Política, Manuel Montt 056, CasiIla 15 - D, Temuco, Chile.

La correspondencia comercial destinada a la compra o suscripción de la Revista deberá dirigirse al correo electrónico editorial@uct.cl 


\section{NORMAS DE REDACCIÓN}

Los idiomas de publicación para los artículos serán el español y el inglés. La periodicidad será semestral. La recepción de trabajos será continua, publicándose en orden de aceptación. Además, se dejará constancia de las respectivas fechas de recepción y aceptación definitiva del manuscrito. La selección de trabajos será responsabilidad del Comité Científico Externo, integrado por académicos americanos y europeos.

El artículo debe enviarse en formato word, tamaño carta, en fuente Arial tamaño 12 y con doble espacio de interlineado.

El artículo no podrá indicar en ninguna de sus páginas dato alguno que permita la individualización de su autor. De este modo, el autor en un documento formato word y separado del artículo deberá indicar su nombre completo, grado académico, filiación institucional (la principal, si tuviere más de una), localidad, ciudad y país de origen, teléfono de contacto y dirección electrónica. Además, en formato word y por separado, deberá adjuntar su currículum vítae.

No se admitirán trabajos publicados con anterioridad, ni en Chile ni en el extranjero. Los artículos que se encuentren incursos en otros arbitrajes editoriales, deberán poner esta circunstancia en conocimiento del director de la Revista al momento de ser enviados. Los trabajos deberán constituir el resultado de una investigación y presentar una extensión máxima de diez mil (10.000) palabras, incluidas las notas al pie de página, y excluyéndose de este total únicamente la bibliografía. Por su parte, la bibliografía deberá presentarse al final del artículo ordenada alfabéticamente. En caso de haber más de una obra de un mismo autor, deben ordenarse cronológicamente, indicando en primer lugar la más antigua.

Todo artículo deberá incluir:

- Título en español e inglés.

- Resumen y abstract (máximo 150 palabras).

- Palabras clave en inglés y español (de tres a cinco).

- Bibliografía citada. 


\section{Forma de referir las fuentes bibliográficas}

Respecto de la bibliografía, la forma de referir las fuentes será la siguiente:

\section{Libros}

1.1 Libros con un solo autor:

Apellidos, nombres, título de la obra, editorial, ciudad y/o país, número de edición (si no es la primera) y año de edición.

1.2 Libros con dos autores:

Apellidos autor 1, nombres autor 1, apellidos autor 2, nombres autor 2, título de la obra, editorial, ciudad y/o país, número de edición (si no es la primera) y año de edición.

\subsection{Libros con tres autores:}

Apellidos autor 1, nombres autor 1, apellidos autor 2, nombres autor 2, apellidos autor 3, nombres autor 3, título de la obra, editorial, ciudad y/o país, número de edición (si no es la primera) y año de edición.

1.4 Libros con cuatro o más autores:

apellidos autor 1 , et al., título de la obra, editorial, ciudad y/o país, número de edición (si no es la primera) y año de edición.

1.5 Libros con editor o coordinador que recopilan artículos de diversos autores: Apellidos del editor o coordinador, nombres del editor o coordinador, título de la obra, editorial, ciudad y/o país, número de edición (si no es la primera) y año de edición.

\section{Artículos de publicaciones periódicas en soporte físico (papel)}

\subsection{Artículos con un solo autor:}

Apellidos, nombres, título del artículo /en/ nombre de la revista, editorial y/o filiación institucional de la revista, número (y/o tomo y/o volumen) y año, ciudad y/o país, página de inicio y página de término del artículo.

2.2 Artículos con dos, tres y cuatro o más autores:

Se seguirá el orden dispuesto para los artículos con un solo autor, aunque la individualización de los autores se hará de acuerdo con lo establecido para los libros con dos, tres y cuatro o más autores respectivamente. 


\section{Artículos de publicaciones periódicas en soporte electrónico}

\subsection{Artículos con un solo autor:}

Apellidos, nombres, título del artículo /en/ nombre de la revista, editorial y/o filiación institucional de la revista, [on line], número (y/o tomo y/o volumen) y año [fecha de la consulta], página de inicio y página de término del artículo. Sitio de internet, mediante la fórmula "Disponible en la Word Wide Web:".

\subsection{Artículos con dos, tres y cuatro o más autores:}

Se seguirá el orden dispuesto para los artículos con un solo autor, aunque la individualización de los autores se hará de acuerdo con lo establecido para los libros con dos, tres y cuatro o más autores respectivamente.

\section{Otros documentos electrónicos}

Apellidos, nombres, título del artículo [on line], [fecha de la consulta]. Sitio de internet, mediante la fórmula "Disponible en la Word Wide Web:".

Respecto de las notas, se seguirán las reglas establecidas para la bibliografía, aunque al final se añadirá el número de páginas. Con todo, en el caso de las publicaciones periódicas no se incluirá página de inicio ni página de término. Las notas deben ser incluidas a pie de página. 
